\title{
Eleocharis R.Br. (Cyperaceae) no Estado do Rio de Janeiro, Brasil
}

\author{
André dos Santos Bragança Gil ${ }^{1,3}$ \& Claudia Petean Bove ${ }^{2}$ \\ Biota Neotropica $v 7(n 1)$ \\ http://www.biotaneotropica.org.br/v7n1/pt/abstract?taxonomic-review+bn00507012007 \\ Recebido em 26/05/06 \\ Versão reformulada recebida em 10/11/06 \\ Publicado em 01/01/07
}

\begin{abstract}
${ }^{1}$ Universidade Estadual de Campinas - UNICAMP, Programa de Pós-Graduação em Biologia Vegetal, Instituto de Biologia, Departamento de Botânica, Barão Geraldo, CEP 13083-970, Campinas, SP, Brasil

${ }^{2}$ Museu Nacional, UFRJ, Departamento de Botânica. Quinta da Boa Vista, São Cristóvão, CEP 20940-040, Rio de Janeiro, RJ, Brasil, http://www.museunacional.ufrj.br

${ }^{3}$ Autor para correspondência: André dos Santos Bragança Gil, e-mail: asbgil@yahoo.com.br,http://www.unicamp.br
\end{abstract}

\begin{abstract}
Gil, A.S.B \& Bove, C.P. Eleocharis R. Br. (Cyperaceae) in Rio de Janeiro State, Brasil. Biota Neotrop. Jan/Apr 2007 vol. 7, no. 1 http://www.biotaneotropica.org.br/v7n1/pt/abstract?taxonomic-review+bn00507012007 ISSN 1676-0603.

A floristic inventory of the species of Eleocharis (Cyperaceae) from Rio de Janeiro State - Brazil was made. This research included material from most important Herbaria of Rio de Janeiro (FCAB, GUA, HB, HUNI, R, RB, RBR, RFA, RUSU) as well as plants collected during expeditions to aquatic ecosystems of Rio de Janeiro, between November 1998 and September 2003. The genus Eleocharis is represented in the area by 19 species: Eleocharis acutangula (Roxb.) Schult., E. debilis Kunth, E. elongata Chapm., E. equisetoides (Elliott) Torr., E. filiculmis Kunth, E. flavescens (Poir.) Urb., E. geniculata (L.) Roem. \& Schult., E. interstincta (Vahl) Roem. \& Schult., E. maculosa (Vahl) Roem. \& Schult., E. minarum Boeck.*, E. minima Kunth, E. montana (Kunth) Roem. \& Schult., E. mutata (L.) Roem. \& Schult., E. nana Kunth, E. pachystyla (C. Wright) C. B. Clarke*, E. radicans (Poir.) Kunth*, E. sellowiana Kunth, E. squamigera Svenson, and E. subarticulata (Nees) Boeck. (*species rare in Rio de Janeiro state). A key of identification, descriptions of species, illustrations, and notes on ecological features and geographical distribution are presented.
\end{abstract}

Keywords: Eleocharis, Cyperaceae, Rio de Janeiro.

\section{Resumo}

Gil, A.S.B \& Bove, C.P. Eleocharis R. Br. (Cyperaceae) no Estado do Rio de Janeiro, Brasil. Biota Neotrop. Jan/Apr 2007 vol. 7, no. 1 http://www.biotaneotropica.org.br/v7n1/pt/abstract?taxonomicreview+bn00507012007 ISSN 1676-0603.

Foi realizado o levantamento das espécies de Eleocharis (Cyperaceae) no Estado do Rio de Janeiro - Brasil, a partir de exsicatas depositadas nos principais herbários do Estado (FCAB, GUA, HB, HUNI, R, RB, RBR, RFA, RUSU), assim como coletadas em excursões a ecossistemas aquáticos na área de estudo, entre novembro de 1998 a setembro de 2003. O gênero Eleocharis está representado no Estado do Rio de Janeiro por 19 espécies: Eleocharis acutangula (Roxb.) Schult., E. debilis Kunth, E. elongata Chapm., E. equisetoides (Elliott) Torr., E. filiculmis Kunth, E. flavescens (Poir.) Urb., E. geniculata (L.) Roem. \& Schult., E. interstincta (Vahl) Roem. \& Schult., E. maculosa (Vahl) Roem. \& Schult., E. minarum Boeck.*, E. minima Kunth, E. montana (Kunth) Roem. \& Schult., E. mutata (L.) Roem. \& Schult., E. nana Kunth, E. pachystyla (C. Wright) C. B. Clarke*, E. radicans (Poir.) Kunth*, E. sellowiana Kunth, E. squamigera Svenson e E. subarticulata (Nees) Boeck (*espécies raras no Estado do Rio de Janeiro). São apresentadas chave de identificação, descrições, ilustrações, informações adicionais de natureza ecológica e distribuição geográfica das espécies de Eleocharis do Estado do Rio de Janeiro.

Palavras-chave: Eleocharis, Cyperaceae, Rio de Janeiro. 


\section{Introdução}

A maior rede hidrográfica do mundo está situada no Brasil, com grande variedade de ecossistemas aquáticos, sendo estes bastante representativos dentre os ecossistemas brasileiros (Bove et al. 2003). O Estado do Rio de Janeiro, localizado entre os paralelos $20 \mathrm{~S} 45^{\prime}$ 46 " e 23 S 22' 46" de latitude Sul e os meridianos 40 W 57' 09" e 44 W 52' 06" de longitude Oeste (Figura 1), apresenta um grande número de ecossistemas aquáticos.

$\mathrm{Na}$ planície costeira do Estado, encontram-se muitas lagoas, lagunas, rios, canais e brejos, e ainda, muitas áreas periodicamente alagáveis adjacentes, que são um dos mais produtivos dentre os ecossistemas aquáticos continentais, por apresentarem grandes comunidades de vegetais hidrófilos. Na região serrana do Estado, encontram-se grandes reservatórios e muitos rios com seus afluentes e respectivas áreas de inundação.

A família Cyperaceae Juss. tem grande destaque pela presença intensiva em muitas regiões e pelo grande número de espécies, inclusive caracterizando os ecossistemas aquáticos (Gil \& Bove 2004). Segundo Bruhl (1995) Cyperaceae é composta por cerca de 5.000 espécies distribuídas em duas subfamílias, 12 tribos e 112 gêneros. Para Goetghebeur (1998) a família é composta também por cerca de 5.000 espécies, porém distribuídas em quatro subfamílias, 14 tribos e 104 gêneros. Judd et al. (2002) concordam que a família apresenta 104 gêneros, porém comportando 4.500 espécies. Porém Soltis et al. (2005) creditam à Cyperaceae um número menor de gêneros (98) e de espécies (4.350). Cyperaceae é uma família cosmopolita, que normalmente, mas não exclusivamente, ocorre em locais úmidos (Goetghebeur 1998, Judd et al. 2002, Soltis et al. 2005). Judd et al. 2002 citam como os maiores gêneros: Carex L. (2000 spp.), Cyperus L. (600 spp.), Fimbristylis Vahl (300 spp.), Scirpus L. (300 spp.), Rhynchospora Vahl (200 spp.), Scleria Berg. (200 spp.) e Eleocharis R. Br. (200 spp.).

Muniz \& Shepherd (1987) sugerem 500 espécies para o Brasil e Luceño et al. (1997), apontam a ocorrência de 600 a 700 espécies distribuídas em 40 a 44 gêneros. Apesar de sua grande representatividade no país, as Ciperáceas têm sido pouco estudadas. Existem duas principais publicações que tratam de flora de Cyperaceae para o Brasil, Nees (1842) para todo o país e Barros (1960) apenas para o estado de Santa Catarina. Listagens e catálogos florísticos regionais são publicados com maior frequiência, entre estes se destacam

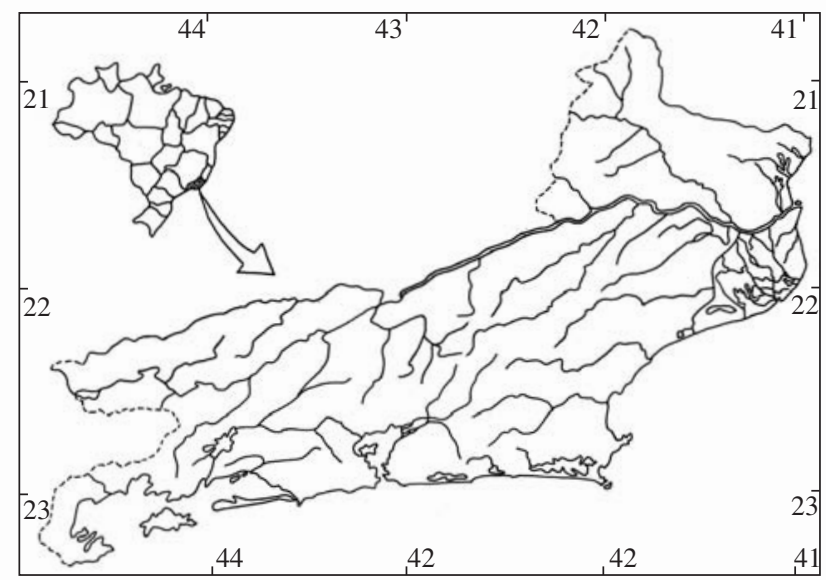

Figura 1. Localização da área de estudo. Acima: vista geral. Abaixo: mapa hidrográfico do Estado do Rio de Janeiro.

Figure 1. Study location area. Above: general view. Below: Rio de Janeiro State hydrographic map. o catálogo de Luceño et al. (1997) para Paraíba e Pernambuco e a listagem de Prata (2002) para o estado de Roraima. Existem, ainda, trabalhos revisionais de alguns grupos taxonômicos e floras de maior amplitude, que incluem espécies brasileiras, entre estes se destacam as contribuições ao gênero Rhynchospora (Guaglianone, 2001) e a Flora Mesoamericana (Adams, 1994).

O gênero Eleocharis possui, aproximadamente, 250 espécies, usualmente aquáticas e anfíbias, distribuídas dos trópicos às regiões polares do mundo e com grande concentração de espécies nas Américas (Diego-Pérez 1997). Segundo Goetghebeur (1998) e González-Elizondo \& Peterson (1997) são cerca de 200 espécies, porém González-Elizondo \& Peterson (1997) citam que existem cerca de 600 nomes publicados, evidenciando um grande número de sinonímias.

Foram realizados alguns trabalhos globais que tratam da classificação infragenérica do gênero Eleocharis, onde se destacam: Svenson (1939), que dividiu as espécies do gênero em nove séries, Kukkonen (1990) que dividiu o gênero em cinco subgêneros, 13 seções e três séries e o de González-Elizondo \& Peterson (1997) que dividiu Eleocharis em quatro subgêneros, sete seções, oito séries e sete subséries. Kukkonen (1990) e González-Elizondo \& Peterson (1997) além de terem estabelecido novas classificações infragenéricas para as Eleocharis, ainda forneceram um grande levantamento histórico sobre as classificações infragenéricas das espécies deste gênero. Roalson \& Friar (2000) realizaram um estudo comparativo entre as três classificações citadas acima (Svenson 1939, Kukkonen 1990, González-Elizondo \& Peterson 1997) com dados obtidos pelo estudo do seqüenciamento de uma região do DNA nuclear ribossômico (ITS), verificando que não há total congruência entre seus resultados e as classificações sugeridas por estes autores, pois muitas das subdivisões sugeridas apresentaram-se parafiléticas ou polifiléticas.

No Brasil são registradas mais de 60 espécies e cerca 80 nomes publicados. Apesar deste grande número de espécies registradas, não há um trabalho que trate, exclusivamente, de levantamento florístico e/ou estudos taxonômicos do gênero Eleocharis para o Brasil. Existem apenas três dissertações de mestrado que abordam as espécies ocorrentes no Estado de São Paulo, com 36 espécies e uma variedade (Faria 1998); no Estado do Rio Grande do Sul, com 27 espécies levantadas (Trevisan 2005) e outra no Estado do Rio de Janeiro, com 19 espécies (Gil 2004).

Eleocharis é um gênero caracteristicamente sem lâminas foliares, com as atividades fotossintéticas transferidas para o colmo (Svenson 1929). A identificação das espécies é muitas vezes difícil, pois sua distinção está geralmente em pequenas estruturas, como: ápice da bainha, glumas inferiores, e principalmente em detalhes da morfologia dos aquênios e de suas estruturas assessórias. As espécies de Eleocharis são emergentes e raramente submersas, ocorrendo em brejos, cachoeiras, lagoas, lagos, margens de rios, pântanos, restingas e solos úmidos de locais abertos (Faria 1998). Condições ótimas de luminosidade e de recursos hídricos são fundamentais para a existência e bom funcionamento das espécies de Eleocharis (Gil \& Bove 2004).

O nome Eleocharis criado por Robert Brown em 1810, é de-

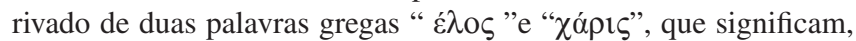
respectivamente, "brejo" e "graça" referindo-se a beleza que estas espécies conferem aos ambientes aquáticos. Ao formar o nome, R. Brown, não incluiu a letra "h" que é utilizada apenas na pronúncia da palavra "brejo" em grego, logo virou motivo de muita controvérsia se a grafia correta seria Eleocharis ou Heleocharis Lestib. Muitos botânicos insistiam na utilização do "h". C. B. Clarke resolveu o problema de maneira muito simples: rejeitando todas as combinações com Heleocharis. Este não é um método atraente ao senso comum, porém, isto vem sendo costumeiro de praticamente todos os botânicos 
que seguem o Index Kewensis, tratando a questão como, meramente, uma variação na ortografia (Svenson 1929).

Svenson (1929) comenta ainda que o nome Heleocharis não poderia ser aceito por 3 motivos: não haver certeza das regras utilizadas na mudança da grafia original (Eleocharis); por combinar duas palavras gregas na formação de uma em Latim, criando assim um novo idioma, e o nome Heleocharis pode ser confundido com nomes formados por "helios" (sol em grego). Segundo o artigo 60 do Código Internacional de Nomenclatura Botânica (Greuter et al. 2000), "a grafia original de um nome ou epíteto deve ser mantida, exceto para correção de erros tipográficos ou ortográficos...”, logo o nome Heleocharis só seria aceito se fosse conservado, já que o "h" foi introduzido na tentativa de se corrigir um erro fonético e não ortográfico ou tipográfico. Janchen (1950) propôs a conservação do nome Heleocharis, porém em 1954 a proposta foi rejeitada pela Associação Internacional de Taxonomia Vegetal, confirmando então o uso do nome Eleocharis para o grupo em estudo.

No presente trabalho objetiva-se contribuir para o conhecimento das espécies do gênero Eleocharis ocorrentes no estado do Rio de Janeiro, fornecer novos dados a respeito de seu estado de conservação, ocorrência e morfologia, visando a melhor definição e caracterização dos táxons em estudo.

\section{Material e Métodos}

O material Botânico utilizado foi proveniente de coletas realizadas em diferentes ecossistemas aquáticos do Estado do Rio de Janeiro, entre novembro de 1998 e setembro de 2003, com periodicidade aleatória, assim como, de exsicatas depositadas nos principais herbários do Estado: Alberto Castellanos (GUA), do Departamento de Botânica do Instituto de Biologia da Universidade Federal do Rio de Janeiro (RFA), Herbarium Bradeanum (HB), Herbarium Friburgense (FCAB), do Instituto de Pesquisas do Jardim Botânico do Rio de Janeiro (RB), do Museu Nacional (R), da Universidade Federal Rural do Rio de Janeiro (RBR) e da Universidade Santa Úrsula (RUSU). Procurou-se coletar inflorescências jovens e maduras, verificando, in situ, características estruturais e ambientais. Os espécimes coletados foram preparados segundo técnicas tradicionais (Mori et al. 1989) e depositados no herbário do Museu Nacional - UFRJ (R).

A chave de identificação e as descrições das espécies foram construídas através dos dados obtidos em detalhadas observações e mensurações do material herborizado, rehidratado e/ou conservados em A.E. $70 \%$.

Os nomes científicos legítimos e os respectivos basiônimos das espécies identificadas estão de acordo com os dados disponíveis no site do Missouri Botanical Garden (2006).

A identificação do material examinado, dados de floração e frutificação, nomes vulgares, habitat e dados sobre distribuição geográfica das espécies em estudo foram obtidos com auxilio da literatura: Roemer \& Schultes (1817), Torrey (1836), Kunth (1837), Nees (1842), Chapman (1860), Sampaio (1916), Molfino (1925), Svenson (1929), Osten (1931), Standley (1931), Svenson (1932,1934,1937), Blake (1938), Svenson (1939), Parodi (1943), Svenson (1943), Muenscher (1944), Kuhlmann \& Kühn (1947), Standley \& Steyermark (1958), Barros (1960), Koyama (1961), Hitchcock et al. (1969), Nelson (1978), Oliveira (1980), Marticorena \& Quezada (1985), Pott et al. (1986), Lawesson et al. (1987), Ueno et al. (1989), Renner et al. (1990), Menapace (1991), Mendoza \& Gonzalez (1991), Ueno \& Takeda (1992), Menapace (1993), Pedralli et al. (1993), González-Elizondo (1994), Jørgensen \& Ulloa (1994), Velasquez (1994), Simpson (1995), González-Elizondo \& Reznicek (1996), González-Elizondo \& Reznicek (1998), Irgang \& Gastal Jr. (1996), Diego-Pérez (1997), Luceño et al. (1997), Pedralli \& Gon- çalves (1997), Pott \& Pott (1997), Araújo et al. (1998), Dubs (1998), Faria (1998), Rosa \& Irgang (1998), Martins et al. (1999), Schessl (1999), Muniz (2001), González-Elizondo et al. (2002), Prata (2002), Bove et al. (2003), Gil \& Bove (2004), Trevisan (2005), Trevisan \& Boldrini (2005), Trevisan \& Boldrini (2006) e das coleções dos herbários consultados. Os dados de distribuição geográfica das espécies identificadas foram complementados com os dados disponíveis no site do Missouri Botanical Garden (2006).

O termo "colmos" citado no texto refere-se ao caule e/ou escapo de Eleocharis.

O termo "espiga" foi utilizado no texto em lugar do termo "espigueta" (tradicionalmente usado para nomear a inflorescência de Eleocharis), pois espigueta refere-se a uma espiga que faz parte de outra espiga ou de outro tipo qualquer de inflorescência, ou seja, espigueta é parte de uma inflorescência composta. Este fato não condiz com a realidade da inflorescência de Eleocharis que é formada por uma espiga única terminal (inflorescência simples).

As "glumas" são estruturas semelhantes a escamas que abrigam as flores aperiantadas de Eleocharis. Quando posicionadas na base das espigas são chamadas de "glumas inferiores", porém estas podem se apresentar estéreis ou férteis. As glumas também podem ser, simplesmente, chamadas de escamas e as inferiores chamadas de glumas basais.

Os "aquênios" citados no texto são os frutos das espécies de Eleocharis, que também podem ser chamados de cipselas ou de núculas.

O termo "estilopódio" foi utilizado para nomear a estrutura que se encontra persistente no ápice dos aquênios, que também pode ser chamada de rostro ou base do estilete.

As medidas nas descrições das espécies, quando não especificadas no texto, são apresentadas da seguinte forma: "comprimento $x$ largura" e para estruturas circulares "comprimento x diâmetro". As medidas do comprimento dos aquênios nas descrições das espécies incluem o estípite.

As siglas dos herbários consultados estão de acordo com Holmgren et al. (1990).

\section{Resultados e Discussão}

\section{Descrição do gênero Eleocharis para área de estudo}

Eleocharis R. Br., Prodr. Fl. N. Hol. 1:224. 1810.

Espécie tipo: Eleocharis palustris (L.) Roem. \& Schult., Syst. Veg. 2:151. 1817.

Ervas eretas ou escandentes, cespitosas, rizomatosas ou estoloníferas. Colmos cilíndricos, subcilíndricos, elípticos, achatados, triangulares de faces côncavas ou convexas, quadrangulares, pentangulares; esponjosos, capilares, regularmente ou irregularmente septados, nodulosos ou não, com septos transversais evidentes ou pouco evidentes, lisos ou longitudinalmente estriados, sulcados ou não. Folhas reduzidas às bainhas, membranáceas ou subcoriáceas, com ou sem apêndice hialino no ápice; ápice oblíquo ou truncado, obtuso, acuminado, cuspidado, aristado, ou mucronado, íntegro ou escarioso. Inflorescências em espiga solitária terminal, sem brácteas involucrais, prolíferas ou não, multifloras ou paucifloras, cilíndricas, lanceoladas, oblongo-lanceoladas, oval-lanceoladas, ovóides, elipsóides, subglobosas, globosas, ou obovóides, agudas a obtusas, com flores bissexuais; glumas espiraladas a dísticas, carenadas ou não, membranáceas ou subcartilaginosas, persistentes ou caducas, oblongas, sub-orbiculares, orbiculares, elípticas, oval-elípticas, ovaladas, oval-lanceoladas, lanceoladas, sub-obovadas, ou obovadas, ápice agudo a obtuso, com margens hialinas, escariosas ou íntegras, nervuras longitudinais proeminentes ou não; glumas inferiores 1-3(4), 
articuladas ou contínuas com o colmo, estéreis ou férteis, caducas ou persistentes, margens hialinas ou pardas, íntegras ou escariosas, ápice agudo a obtuso, ou ainda, emarginado. Cerdas perigoniais 0 (raro) 3-9, retrorsamente escabras, persistentes no aquênio, maiores, menores ou do mesmo comprimento que o aquênio, ou ainda, vestigiais. Estames 1-3, com filetes hialinos a castanhos; anteras basifixas, de deiscência longitudinal, apiculadas ou não. Ovário 2-3 carpelar; estilete glabro, com base persistente no ápice do aquênio; estigmas 23 -fidos. Aquênios obovóides, elipsóides, sub-orbiculares, ou globosos, lenticulares, sub-rotundos ou trígonos, de superfície lisa, lustrosa, reticulada, estriada, pontuada ou com fileiras longitudinais de células arredondadas, retangulares a hexagonais, 2-3-costados ou acostados, estipitados ou não, ápice com colo ou espessamento onde se insere o estilopódio; estilopódio deprimido, cônico, cônico-comprimido, horizontalmente ou lateralmente, piramidal ou discóide.

\section{Chave analítica para a identificação das espécies de Eleocharis ocorrentes na área de estudo:}

1. Espigas cilíndricas; glumas subcartilaginosas pelo menos em sua região central.

2. Colmos cilíndricos.

3. Colmos regularmente septados, com septos transversais evidentes; aquênios lenticulares, 2-costados ou acostados; estilopódio cônico comprimido lateralmente.

4. Colmos com um feixe vascular contínuo no centro de um grande canal de ar, estriados longitudinalmente; uma gluma inferior; aquênios 2-costados.

4. Eleocharis equisetoides

4'. Colmos sem feixe vascular contínuo no centro de um grande canal de ar, lisos; duas glumas inferiores; aquênios acostados.

8. Eleocharis interstincta

3'. Colmos irregularmente septados, com septos transversais pouco evidentes; aquênios trígonos, 3-costados; estilopódio piramidal.

2'. Colmos triangulares.

3. Eleocharis elongata

5. Colmos de faces côncavas; gluma inferior estéril; aquênio com espessamento no ápice. com colo no ápice.

13. Eleocharis mutata

\section{Eleocharis acutangula}

1'. Espigas lanceoladas, oblongo-lanceoladas, oval-lanceoladas, ovóides, elipsóides, subglobosas, globosas, ou obovóides; glumas membranáceas (exceto em E. minarum).

6. Superfície dos aquênios com fileiras longitudinais de células retangulares dispostas horizontalmente.

7. Colmos subcilíndricos a inconspicuamente pentagonais; espigas lanceoladas a oblongo-lanceoladas, castanho-claras; glumas lanceoladas, ápice agudo a subagudo, com nervuras longitudinais não proeminentes, 2,2-2,5 mm; gluma inferior fértil, 2-2,3 mm; 3 cerdas perigoniais, alvas a amareladas, 2-2,5 mm; aquênios (imaturos) elipsóides.

16. Eleocharis radicans

7'. Colmos quadrangulares; espigas ovóides a elipsóides, castanho-avermelhadas com manchas pardo-esverdeadas; glumas oval-lanceoladas a ovaladas, ápice obtuso, com nervura longitudinal central proeminente, 1,5-2 mm; gluma inferior estéril, 1-1,5 mm; 6 cerdas perigoniais, castanhas, 0,7-1,2 mm; aquênios obovóides.

\section{Eleocharis squamigera}

6'. Superfície dos aquênios lisa, reticulada, estriada, pontuada, com fileiras longitudinais de células arredondadas pouco evidentes ou de células retangulares dispostas verticalmente.
8. Aquênios negros a castanhos ou oliváceos.

9. Bainha com apêndice hialino no ápice.

10. Colmos septados; bainha com inconspícuo apêndice hialino no ápice; glumas inferiores persistentes; 6 cerdas perigoniais; aquênios trígonos, 3-costados, estípite ausente; estilopódio contínuo com o aquênio, piramidal.

19. Eleocharis subarticulata

10'. Colmos esponjosos; bainha com evidente apêndice hialino no ápice; glumas inferiores caducas; 7-9 cerdas perigoniais, raro ausentes; aquênios lenticulares; 2-costados, estipitados, ápice com um colo onde se insere o estilopódio; estilopódio cônico comprimido lateral ou horizontalmente.

11. Colmos não sulcados; espigas amareladas a pardo-esverdeadas; estilopódio cônico horizontalmente comprimido (discóide).

6. Eleocharis flavescens

11'. Colmos sulcados; espigas de outras cores; estilopódio cônico lateralmente comprimido.

12'. Colmos pontuados; aquênios negros a castanhoescuros, superfície inconspicuamente reticulada.

9. Eleocharis maculosa

12. Colmos não pontuados; aquênios oliváceos a castanho-claros, superfície lisa.

\section{Eleocharis sellowiana}

9'. Bainha sem apêndice hialino no ápice.

13. Colmos septados; ápice da bainha mucronado; espigas oblongo-lanceoladas a oval-lanceoladas quando maduras e obovóides a oblongas quando imaturas; glumas inferiores persistentes; estames 1-2; aquênios oliváceos, castanho-pálidos, ou ainda, castanho-esverdeados, superfície com fileiras longitudinais de células retangulares dispostas verticalmente e pontuada.

12. Eleocharis montana

13'. Colmos inconspicuamente esponjosos ou capilares; ápice da bainha cuspidado a apiculado ou obtuso; espigas ovóides a globosas, raro elipsóides; glumas inferiores caducas; estames 3; aquênios negros a negro-purpúreos e/ou castanho-escuros, superfície lisa.

14. Colmos quadrangulares a inconspicuamente elípticos, capilares; ápice da bainha obtuso, escarioso; glumas ovaladas a oval-lanceoladas, ápice subagudo; anteras sem apículo; estilopódio cônico comprimido lateralmente.

2. Eleocharis debilis

14'. Colmos cilíndricos a achatados, inconspicuamente esponjosos, ápice da bainha cuspidado a apiculado, íntegro; glumas elípticas a orbiculares, ápice obtuso, anteras brevemente apiculadas; estilopódio cônico horizontalmente comprimido (discóide).

7. Eleocharis geniculata

8'. Aquênios alvos, alvo-esverdeados, amarelados ou amarelo-escuros.

15. Colmos cilíndricos ou pentangulares, septados ou inconspicuamente esponjosos; duas glumas inferiores.

16. Colmos 41-91 cm, cilíndricos, septados; ápice da bainha acuminado; espigas pardo-esverdeadas; glumas com nervura longitudinal central internamente proeminente; apículo ausente nas anteras; aquênio estipitado.

15. Eleocharis pachystyla

16'. Colmos 8-31 cm de comprimento, pentangulares, inconspicuamente esponjosos; ápice da bainha cuspidado; espigas castanho a castanho-avermelhadas; glumas com nervuras longitudinais não proeminentes; anteras brevemente apiculadas; aquênio não estipitado. 


\section{Eleocharis filiculmis}

15'. Colmos quadrangulares, capilares; uma gluma

inferior.

17. Plantas rizomatosas; colmos $25,5-53 \mathrm{~cm}$; bainhas com 4-5,5 cm, ápice inconspicuamente mucronado; glumas subcartilaginosas na região central, membranáceas em direção as margens, persistentes, ápice agudo, margens castanho-avermelhadas, com nervura longitudinal central proeminente; anteras sem apículo; aquênios globosos; estilopódio contínuo com o ápice do aquênio.

10. Eleocharis minarum

17'. Plantas estoloníferas, ou sem rizomas e estolões; colmos 2-16 cm; bainhas com 0,5-2,5 cm, ápice acuminado a obtuso; glumas membranáceas, caducas, ápice subagudo a obtuso, margens hialinas, nervuras longitudinais não proeminentes; anteras apiculadas; aquênios elipsóides ou obovóides, ápice com um colo onde se insere o estilopódio.

18. Estolões e rizomas ausentes; ápice da bainha de base inteira; espigas prolíferas, elipsóides, castanhas; glumas dísticas a subdísticas, elípticas a lanceoladas; gluma inferior persistente, ápice agudo; anteras brevemente apiculadas; Aquênios alvos, elipsóides, superfície com fileiras longitudinais de células arredondadas pouco evidentes.

\section{Eleocharis minima}

18'. Estolonífera; ápice da bainha com pequena fenda na base; espigas não prolíferas, ovóides a oval-lanceoladas, creme-esverdeadas; glumas espiraladas, ovaladas; gluma inferior caduca, ápice obtuso, raro subagudo; anteras longamente apiculadas; Aquênios alvo-esverdeados a amarelados, obovóides, superfície inconspicuamente estriada.

\section{Eleocharis nana}

\section{Descrições das espécies de Eleocharis ocorrentes na área de estudo:}

1. Eleocharis acutangula (Roxb.) Schult., Mant. 2:91. 1824. (Figuras 2-4)

\section{Scirpus acutangulus Roxb., Fl. Ind. 1:216. 1820.}

Ervas eretas, cespitosas, estoloníferas. Colmos $29-100 \mathrm{~cm} \mathrm{x}$ 2-5 mm na base, triangulares de faces convexas, às vezes, com ângulos alados, esponjosos, lisos, sulcos ausentes, verdes. Bainhas membranáceas, purpúreas na base, pardas a purpúreas no ápice, 9$22 \mathrm{~cm}$ de comprimento, sem apêndice hialino no ápice; ápice oblíquo, acuminado, íntegro. Espigas multifloras, proliferação ausente, cilíndricas, 1,5-4,5 $\mathrm{cm} \times 2,5-4 \mathrm{~mm}$, agudas a subagudas, castanho-claras a esverdeadas. Glumas espiraladas, carenadas, subcartilaginosas, persistentes, esverdeadas a pardas na endurecida carena, lados pardos a castanho-claros, com uma faixa castanha submarginal, castanhopontuadas internamente, ovaladas a oval-elípticas, ápice obtuso, às vezes, subagudo, margem hialina, escariosa no ápice, nervuras longitudinais proeminentes, principalmente a central, 3,5-5 x 2,5-3,5 mm. Uma gluma inferior englobando toda a base da espiga, contínua com o colmo, fértil, persistente, verde a parda, $4-5 \mathrm{~mm}$ de comprimento e 2-2,5 mm de diâmetro, margem hialina e escariosa, ápice obtuso. Cerdas perigoniais (6)7, creme-pálidas a castanhas, 2,5-3 mm de comprimento. Estames 3, filetes hialinos, anteras apiculadas, amarelas com máculas castanhas. Estigma (2)3-fido. Aquênios esverdeados a castanho-avermelhados, obovóides, 1,5-2 x 1-1,5 mm, lenticulares, superfície com fileiras longitudinais de células retangulares a hexagonais, acostados, estípite ausente, ápice com um colo; estilopódio castanho-claro a escuro, cônico comprimido lateralmente, $0,5-1 \mathrm{~mm}$ de comprimento.

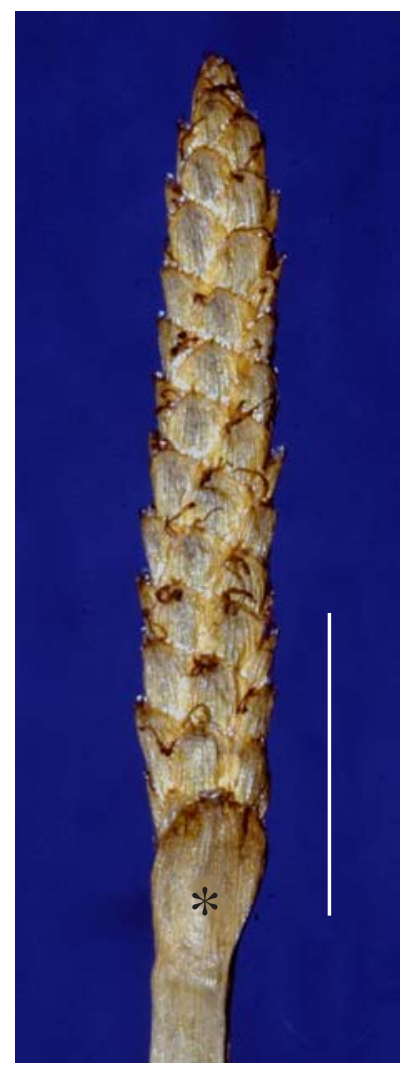

Figura 2. Eleocharis acutangula (Roxb.) Schult. (A. Gil \& B. Figueira 30). Espiga (*gluma inferior) (barra $=10 \mathrm{~mm}$ ).

Figure 2. Eleocharis acutangula (Roxb.) Schult. (A. Gil \& B. Figueira 30). Spike (*lower glume) (scale bar $=10 \mathrm{~mm})$.

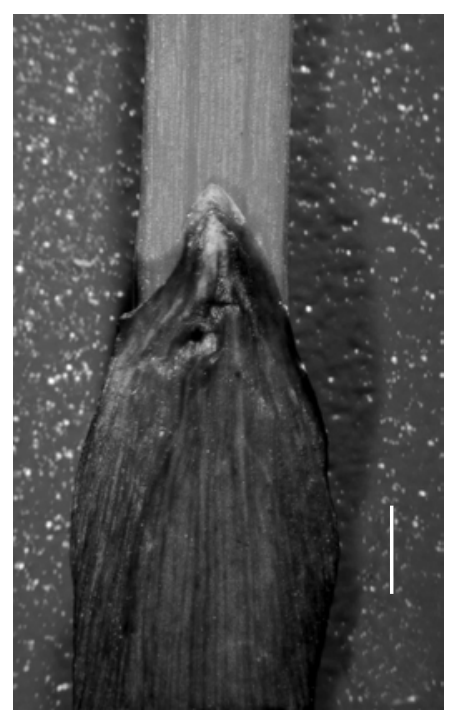

Figura 3. Eleocharis acutangula (Roxb.) Schult. (A. Gil \& B. Figueira 30). Ápice da bainha (barra $=1 \mathrm{~mm}$ ).

Figure 3. Eleocharis acutangula (Roxb.) Schult. (A. Gil \& B. Figueira 30), Sheath apex (scale bar $=1 \mathrm{~mm})$.

Nomes vulgares: junco, cebola-d'água, cebolinha, junco-detrês-quinas e taboinha.

Distribuição geográfica: AMÉRICA: Estados Unidos, México, Cuba, Jamaica, Belize, Guatemala, Honduras, El Salvador, Nicarágua, Costa Rica, Antilhas, Panamá, Venezuela, Colômbia, Ilhas Galápagos, 


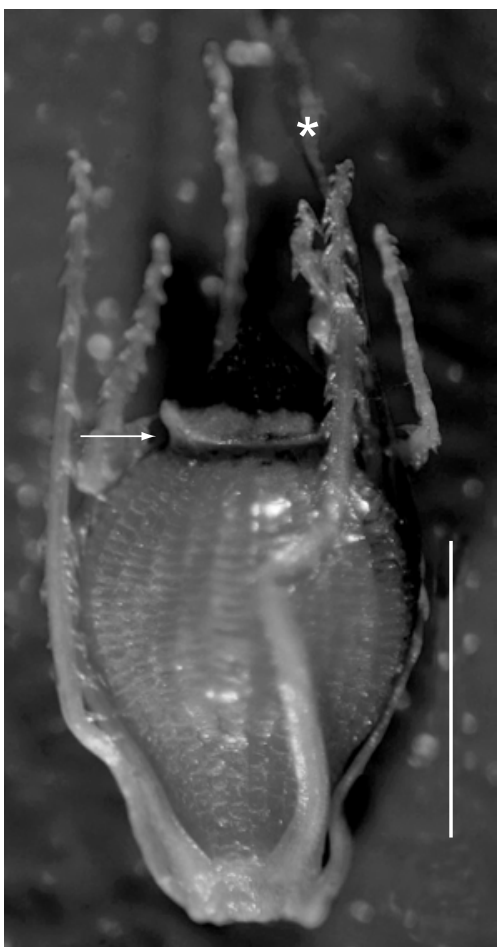

Figura 4. Eleocharis acutangula (Roxb.) Schult. (A. Gil \& B. Figueira 30). Aquênio com seta indicando o colo no ápice (*filete) (barra $=1 \mathrm{~mm}$ ).

Figure 4. Eleocharis acutangula (Roxb.) Schult. (A. Gil \& B. Figueira 30). Achene with an arrow indicating apex neck (*filament) $($ scale bar $=1 \mathrm{~mm})$.

Brasil (RR, PE, BA, MT, GO*, MS, MG, RJ, SP, SC e RS), Equador, Peru, Bolívia, Paraguai e Argentina. ÁFRICA: Sudão, Senegal, Gâmbia, Serra Leoa, Togo, Camarões, República Centro-Africana, Congo, Zâmbia e Madagascar. ÁSIA: China, Japão, Índia e Filipinas. OCEANIA: Nova Guiné e Austrália. * Nova ocorrência.

Floração e frutificação: janeiro, abril, maio, outubro e novembro.

Habitat: brejos herbáceos, canais, margem de lagoas e poças.

Material examinado: BRASIL: RIO DE JANEIRO: Cambuci, Três Irmãos, 21 S 37', 41 W 59', V-1920, A. J. Sampaio 3296 (R); Quissamã, 22 S 06', 41 W 28' lado direito da ponte do Imbiú, a $13 \mathrm{~km}$ da prefeitura e a $8 \mathrm{~km}$ do trevo sentido praia de João Francisco, 11-XI-2002, A. Gil et al. 44 (R); Carapebus, 22 S 11', 41 W 39' Parque Nacional da Restinga de Jurubatiba, Lagoa Paulista, 21-X-2003, C. P. Bove et al. 1265 (R); Rio das Ostras, 22 S 31', 41 W 56', 3-I-2000, R. Anjos et al. 15 (R); Maricá, 22 S 55', 42 W 49', São José do Imbassaí, Lagoa de Maricá, a 4,2 km da entrada para as lagoas de Maricá, 03-XI-2003, A. Gil \& B. Figueira 30 (R); Teresópolis, 22 S 24', 42 W 57', 07-IV-1917, A. Sampaio 2166 (R); Barra do Piraí, Ipiabas, 22 S 22', 43 W 52', 1934, W. Peckolt s/n.(R-44.020); Duque de Caxias, Xerém, 22 S 34', 43 W 18', comunidade Lamarão, sítio das Andorinhas, 26-IV-2003, L.G. S. M. \& José Luis S. P. 434b (R).

Material adicional examinado: BRASIL: GOIÁS: Aruanã, 14 S 55', 51 W 04', Estrada Aruanã-Araguapaz, a 22,4 km de Aruanã, 15-XI-1999, C. P. Bove et al. 601 (R);

Comentários: Eleocharis acutangula é uma espécie muitas vezes confundida com E. mutata em coleções de herbário, pois as principais características distintivas entre estes táxons são visíveis in situ, como a forma do colmo: triangular de faces convexas em E. acutangula e triangular de faces côncavas em E. mutata; ou com o auxílio de um estereomicroscópio: gluma inferior fértil e aquênio com um colo

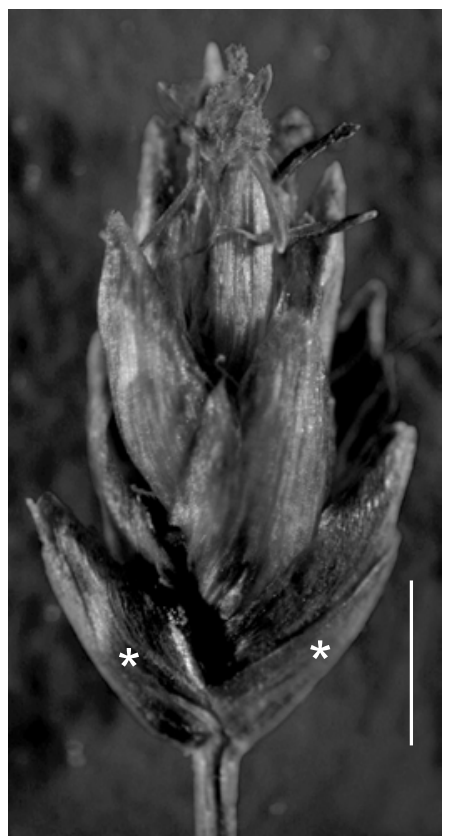

Figura 5. Eleocharis debilis Kunth. (C. P. Bove et al. 1079). Espiga (*glumas inferiores) (barra $=1 \mathrm{~mm}$ ).

Figure 5. Eleocharis debilis Kunth. (C. P. Bove et al. 1079). Spike (*lower glumes) (scale bar $=1 \mathrm{~mm}$ ).

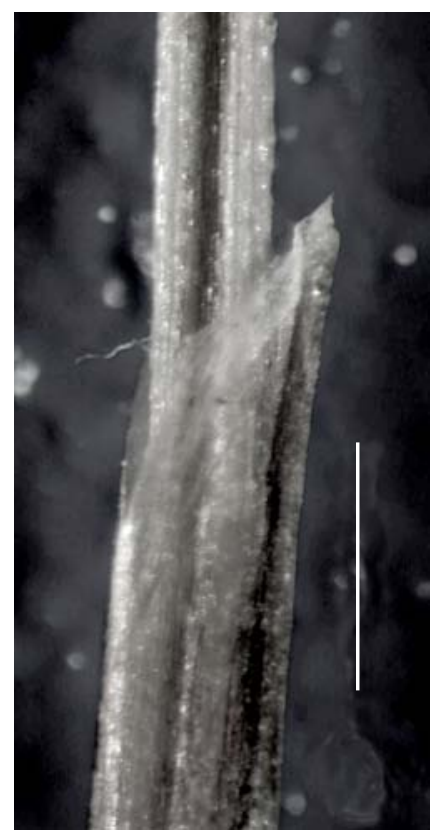

Figura 6. Eleocharis debilis Kunth. (C. P. Bove et al. 1079). Ápice da bainha (barra $=0,5 \mathrm{~mm})$.

Figure 6. Eleocharis debilis Kunth. (C. P. Bove et al. 1079). Sheath apex (scale bar $=0.5 \mathrm{~mm})$.

no ápice em E. acutangula e gluma inferior estéril e aquênio com espessamento no ápice E. mutata.

\section{Eleocharis debilis Kunth, Enum. Pl. 2: 143. 1837. (Figuras 5-8)}

Ervas eretas, cespitosas, rizomatosas. Colmos 3,5-21 cm x 0,2-0,5 $\mathrm{mm}$ na base, quadrangulares a inconspicuamente elípticos, capilares, estriados longitudinalmente, brevemente sulcados, verdes. 


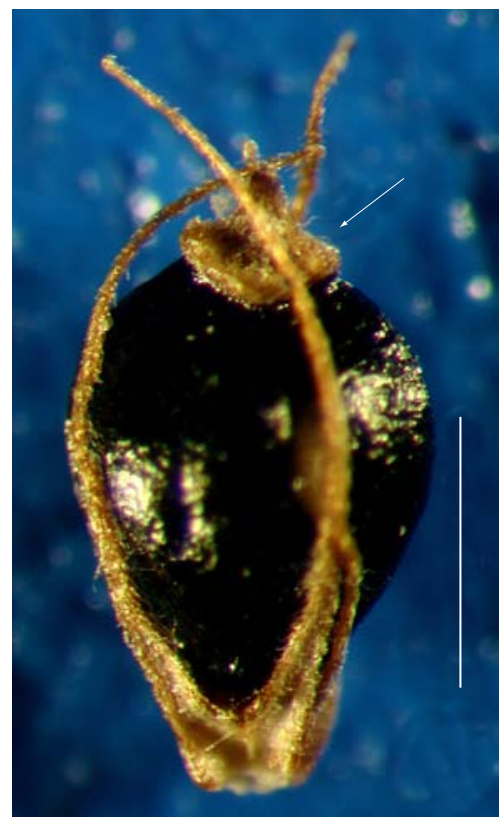

Figura 7. Eleocharis debilis Kunth. (C. P. Bove et al. 1079). Aquênio com seta indicando estilopódio (barra = 0,5 $\mathrm{mm}$ ).

Figure 7. Eleocharis debilis Kunth. (C. P. Bove et al. 1079). Achene with an arrow indicating stylopodium (scale bar $=0.5 \mathrm{~mm}$ ).

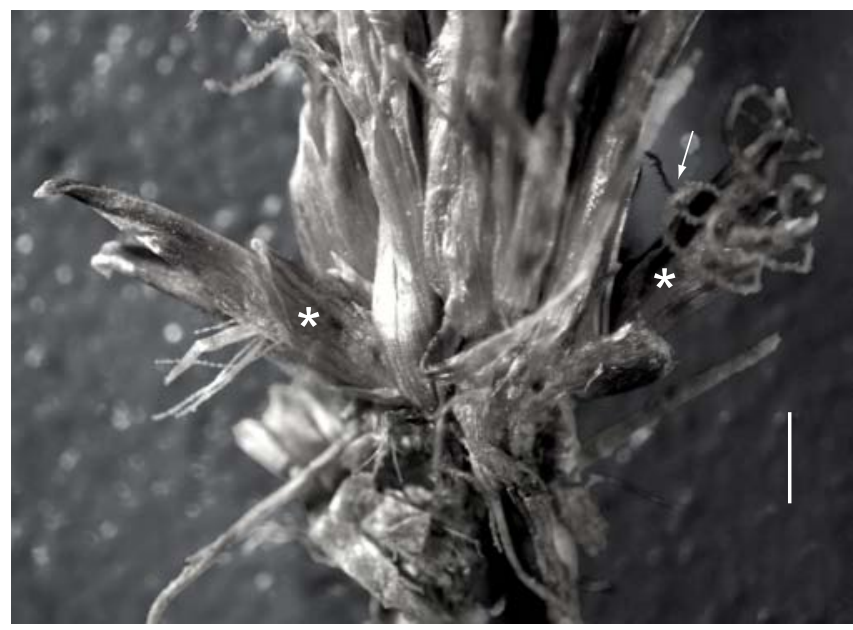

Figura 8. Eleocharis debilis Kunth. (C. P. Bove et al. 1079). *Espigas anficárpicas com seta indicando estigmas (barra $=1 \mathrm{~mm}$ ).

Figure 8. Eleocharis debilis Kunth. (C. P. Bove et al. 1079). * Amphicarpic spikes with an arrow indicating stigmas (scale bar $=1 \mathrm{~mm}$ ).

Bainhas subcoriáceas a membranáceas, purpúreas a pardas na base, verdes a pardo-pálidas em direção ao ápice, 0,8-2 cm de comprimento, sem apêndice hialino no ápice; ápice oblíquo, obtuso, escarioso. Espigas paucifloras, proliferação ausente, ovóides, raro elipsóides, 2-5 x 1-3 mm, agudas, castanho a ocráceas. Glumas espiraladas, raro subdísticas, carenadas, membranáceas, caducas, carena verde, lados castanho-avermelhados, às vezes, metade inferior esverdeados, ovaladas a oval-lanceoladas, ápice subagudo, margens hialinas, íntegras, apenas a nervura longitudinal central proeminente, verde, 1,6-2,2 $\mathrm{x}$ 0,8-1,3 mm. Duas glumas inferiores, a mais externa contínua com o colmo, estéril, carena verde proeminente, lados castanho-avermelhados a pardo-hialinos; a mais interna oposta à externa, articulada com o colmo, fértil, carena verde, lados castanho-avermelhados, às vezes, esverdeados na metade inferior, ambas com 1,5-2 x 0,8$1 \mathrm{~mm}$, caducas, margem hialina e íntegra, ápice obtuso. Cerdas perigoniais (6)7, pardas à castanho-claras, 1-1,8 mm de comprimento. Estames 3, filetes hialinos a acastanhados, anteras sem apículo, amarelas a castanhas. Estigma 2-fido. Aquênios castanho-escuros a negros, obovóides, 0,8-1 x 0,6-0,8 mm, lenticulares, superfície lisa e lustrosa, 2-costados, estipitados, ápice com um colo; estilopódio alvo a castanho-claro, cônico comprimido lateralmente, menor que $0,5 \mathrm{~mm}$ de comprimento.

Nome vulgar: junco.

Distribuição geográfica: AMÉRICA: Cuba, Belize, Honduras, Venezuela e Brasil (PE, MG, RJ, SP, PR e SC).

Floração e frutificação: março, abril, maio, agosto e outubro.

Habitat: cachoeiras, margem e entre pedras de rios.

Material examinado: BRASIL: RIO DE JANEIRO: Nova Friburgo, Lumiar, 22 S 20', 42 W 19', Rio Bonito, 28-IV-2002, C. H. R. de Paula 382 (RUSU); Idem, ibidem, Poço Feio, 14-V-2002, C. P. Bove et al. 1044 (R); Duque de Caxias, 22 S 47', 43 W 18', Reserva da Petrobrás, arredores do alojamento, 31-VIII-1999, J. M. A. Braga et al. 5413 (RB); Angra dos Reis, Ilha Grande, 23 S 08', 44 W 10', vila de Dois Rios, trilha para a praia da Parnaióca, 5-III-2002, F. Pinheiro et al. 352 (HB); Parati, 23 S 13', 44 W 42', entre Parati e Parati Mirim, na metade do caminho, 15-X-2002, C. P. Bove et al. 1079 (R); s/localidade, 1878, Siqueira s/n (R-17996).

Comentários: Eleocharis debilis caracteriza-se por apresentar colmos capilares, ápice da bainha oblíquo e obtuso, espiga ovóide a elipsóide, aguda, castanha a ocrácea e aquênios castanho-escuros a negros. Dentre as espécies de Eleocharis com colmos capilares encontradas no Estado do Rio de Janeiro, E. debilis é a única com aquênios negros.

O espécime de E. debilis do município de Parati foi o único dentre todos os espécimes de Eleocharis examinados neste trabalho que apresentou anficarpia (Figura 8), ou seja, quando a planta apresenta tanto espigas aéreas (no ápice do colmo), quanto basais (junto às raízes e/ou subterrâneas) (Bruhl, 1994). E. debilis é a única espécie examinada neste trabalho com esta característica.

\section{Eleocharis elongata Chapm., Fl. South. U. S.: 515. 1860. (Figuras 9-11)}

Ervas eretas, cespitosas, estoloníferas. Colmos 16-102 cm x 0,7-4 mm na base, cilíndricos, irregularmente septados, por vezes, nodulosos, septos transversais pouco evidentes, lisos a estriados longitudinalmente, sulcos ausentes, verdes. Bainhas membranáceas, pálidas a purpúreas, 4-25 cm de comprimento, sem apêndice hialino no ápice; ápice oblíquo, acuminado, íntegro. Espigas multifloras, por vezes, paucifloras, proliferação ausente, cilíndricas, 1-3,3 cm x 1,5-3 mm, agudas, castanho-esverdeadas. Glumas espiraladas, carenadas, subcartilaginosas, caducas, esverdeadas a castanho-claras na carena, com uma faixa violácea a castanho-escura beirando internamente a margem, por vezes, castanho-escuras, elípticas a ovaladas, ápice subagudo, margem escariosa no ápice, nervuras longitudinais não proeminentes, 3-5 × 2-3 mm. Uma gluma inferior englobando toda a base da espiga, contínua com o colmo, fértil, persistente, castanhoesverdeada a verde, manchas castanho-avermelhadas submarginais, margens hialinas e escariosas, 3-5 mm de comprimento e 1,5-2 mm de diâmetro, ápice subagudo. Cerdas perigoniais 7 (8-9), estramínea a castanho-claras, 1,5-2,5 mm de comprimento. Estames 3, filetes castanhos a negros na base e hialinos próximo a antera, anteras brevemente apiculadas, amarelas, por vezes, com máculas castanhas. Estigma 3-fido. Aquênios pálido-esverdeados a castanho-claros, obovóides, 1-1,5 x $1 \mathrm{~mm}$, trígonos, superfície com fileiras longitudinais de células retangulares bem evidentes, 3-costados, estípite ausente, 


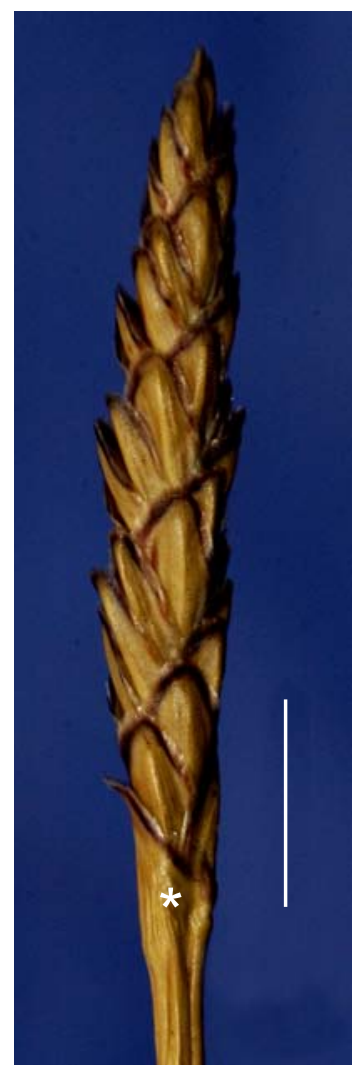

Figura 9. Eleocharis elongata Chapm. (A. Gil et al. 42). Espiga (*gluma inferior) (barra $=5 \mathrm{~mm}$ ).

Figure 9. Eleocharis elongata Chapm. (A. Gil et al. 42). Spike (*lower glume) (scale bar $=5 \mathrm{~mm})$.

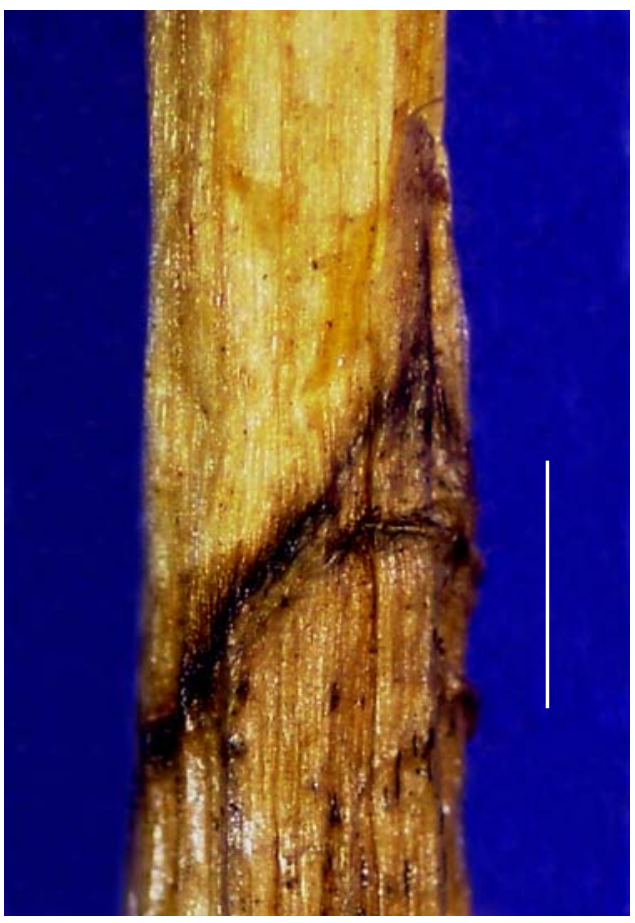

Figura 10. Eleocharis elongata Chapm. (A. Gil et al. 42). Ápice da bainha (barra $=1 \mathrm{~mm})$.

Figure 10. Eleocharis elongata Chapm. (A. Gil et al. 42). Sheath apex (scale bar $=1 \mathrm{~mm})$.

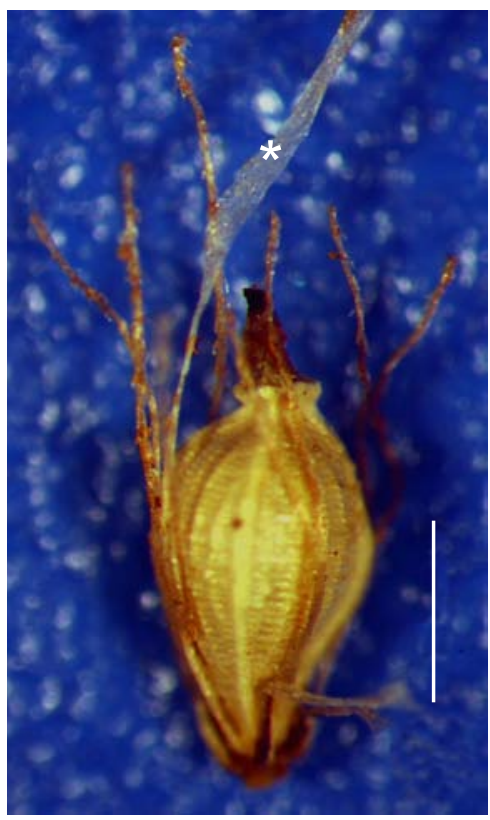

Figura 11. Eleocharis elongata Chapm. (A. Gil et al. 42). Aquênio (*filete) (barra $=1 \mathrm{~mm})$.

Figure 11. Eleocharis elongata Chapm. (A. Gil et al. 42). Achene (*filament) (scale bar $=1 \mathrm{~mm})$.

ápice com um colo; estilopódio pardo-esverdeado a castanho-escuro, piramidal, 0,5-1 mm de comprimento.

Nomes vulgares: junco e cebola-d'água.

Distribuição geográfica: AMÉRICA: Estados Unidos, Nicarágua e Brasil (RJ, SP, SC e RS)

Floração: 0 ano inteiro.

Frutificação: janeiro, fevereiro, abril, maio, agosto, setembro, outubro e novembro.

Habitat: alagados entre dunas, brejos próximos à praia, canais e lagoas.

Material examinado: BRASIL: RIO DE JANEIRO: Campos dos Goytacazes, 21 S 45', 41 W 19', Rio das Pedras, próximo a Lagoa Feia, 8-X-1979, D. Araújo \& N. C. Maciel 3256 (GUA); Quissamã, 22 S 06', 41 W 28', lado direito da ponte do Imbiú, a 13 km da Prefeitura e a 8 km do trevo sentido praia de João Francisco, 11-XI-2002, A. Gil et al. 42 (R); Idem, a 30 km da Prefeitura, Parque Nacional da Restinga de Jurubatiba, Lagoa Paulista, 13-XI-2002, A. Gil et al. 54

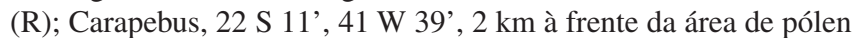
e biologia floral, 18-X-1995, I. M. Silva et al. 298 (R); Idem, Lagoa Comprida, 30-IX-1999, C. P. Bove et al. 448 (R); Idem, ibidem, Faz. São Lázaro, 30-IX-1999, C. P. Bove et al. 455 (R); Idem, ibidem, Parque Nacional da Restinga de Jurubatiba, 20-X-2003, C. P. Bove et al. 1226 (R); Idem, Parque Nacional da Restinga de Jurubatiba, Lagoa Paulista, 22-X-2003, C. P. Bove et al. 1295 (R); Casimiro de Abreu, Barra de São João, 22 S 35', 41 W 59', 1 km norte da Aldeia da Barra de São João, 4-IX-1953, Segadas-Vianna et al. Restinga I-932 (R); Idem, ibidem, 6-XI-1987, K. Tanizaki 81 (RFA); Idem, ibidem, 29-XI-1987, A. A. M. de Barros et al. 228 (RFA); Silva Jardim, 22 S 39', 42 W 23', Vale do Rio São João, Fazenda Dilvo Perez, IX-1986, D. Teixeira s.n. (GUA); Cabo Frio, 22 S 52', 42 W 01', Estrada entre Lagoa de Araruama e Estrada Cabo Frio - Arraial do Cabo, 16-VIII1953, Segadas-Vianna et al. Restinga I-59 (R); Arraial do Cabo, 22 S 57', 42 W 01', Praia do Pontal, II/III-1951, Segadas-Vianna 4167 (R); Idem, ibidem, 17-VI-1952, L. B. Smith 6558a (R); Idem, ibidem, 7-V-1953, Segadas-Vianna et al. Restinga I-44 (R); Idem, ibidem, 24-V-1953, Segadas-Vianna et al. Restinga I-333 (R); Idem, ibidem, 
11-VII-1953, Segadas-Vianna et al. Restinga I-47 (R); Idem, ibidem, 10-VII-1953, Segadas-Vianna et al. Restinga I-48 (R); Maricá, 22 S 55', 42 W 49', Barra de Maricá, 10-X-1983, D. Araújo \& L. D. Lacerda 5734 (GUA); Idem, ibidem, 19-X-1987, A. A. M. de Barros 135 \& K. Tanizaki 55 (GUA); Idem, Restinga de Maricá, 1-I-1990, A. Souza 2863 (R); Idem, ibidem, Zacarias, 22-XI-1998, C. P. Bove \& W. Costa 333 (R); Idem, Itaipuaçu, próximo à praia, região da Pousada Peixão, 3-II-2000, R. Anjos et al. 38 (R); Idem, 22-X-2000, C. P. Bove et al. 752 (R); Duque de Caxias, 22 S 47', 43 W 18', 12 VII-1973, C. R. Campelo s/n (RBR- 4722); Rio de Janeiro, 22 S 54', 43 W 12', Restinga de Jacarepaguá, entre a Pedra de Itaúna e Av. das Américas, 25-V-1981, M. B. Casari et al. 538 (GUA).

Comentários: esta espécie caracteriza-se por suas espigas cilíndricas, agudas e castanho-esverdeadas, colmos cilíndricos, com mais ou menos a mesma largura das espigas, irregularmente septados, com septos transversais pouco evidentes; aquênios trígonos, com fileiras longitudinais de células retangulares bem evidentes, 3-costados e estilopódio piramidal. Nas coleções de herbário apresenta-se, muitas vezes, estéril com um apículo enegrecido no ápice do colmo ou com marcas de herbivoria. E. elongata apresenta uma grande amplitude em relação às suas medidas (comprimento e largura dos colmos e espigas), o que lhe confere grande polimorfismo. A sua descrição original (Chapman 1860) mostrou-se incompleta, já que todo o polimorfismo encontrado nesta espécie não foi citado pelo autor.

Eleocharis elongata pode ser confundida com E. subarticulata, porém E. subarticulata apresenta glumas membranáceas, gluma inferior pequena e estéril, aquênio reticulado e ausência de um colo no ápice do aquênio, enquanto que E. elongata possui rizomas, glumas subcoriáceas, gluma inferior grande e fértil, aquênios com fileiras longitudinais de células retangulares e um colo no ápice do aquênio.

4. Eleocharis equisetoides (Elliott.) Torr., Ann. Lyceum. Nat. Hist. New York. 3: 216. 1836. (Figuras 12-15)

\section{Scirpus equisetoides Elliott., Sk. S. Car. 1(1): 79.1816.}

Ervas eretas, cespitosas, estoloníferas. Colmos $57-82 \mathrm{~cm} \mathrm{x}$ 2-5 $\mathrm{mm}$ na base, cilíndricos, com um feixe vascular contínuo no centro de um grande canal de ar, regularmente septados, por vezes, nodulosos, septos transversais evidentes, estriados longitudinalmente, sulcos ausentes, verdes. Bainhas membranáceas, creme-esverdeadas na base, pardas a castanho-purpúreas em direção ao ápice, 16-27 cm de comprimento, sem apêndice hialino no ápice; ápice truncado a oblíquo, acuminado, íntegro. Espigas multifloras, proliferação ausente, cilíndricas, 2,4-3,5 cm x 3-4 mm, agudas, ocráceas a pardas. Glumas espiraladas, bastante imbricadas, não carenadas, subcartilaginosas na parte central, principalmente na parte superior endurecida, membranáceas nas margens, caducas, pardas no centro, com uma faixa castanho-escura submarginal à margem apical, castanho-pontuadas internamente, oblongas, por vezes, sub-obovadas, ápice obtuso, margem hialina e escariosa, nervuras longitudinais não proeminentes, 3-4,5 x 2-3 mm. Uma gluma inferior englobando toda a base da espiga, contínua com o colmo, estéril, persistente, verde com uma faixa castanha submarginal, 2-5 $\mathrm{mm}$ de comprimento e 2-3,5 $\mathrm{mm}$ de diâmetro, margem hialina e escariosa, ápice obtuso, hialino. Cerdas perigoniais 7 , estramínea a pardo-claras na base escurecendo em direção ao ápice castanho, 1,5-2 mm de comprimento. Estames 3, filetes hialinos ou acastanhados, anteras longo-apiculadas, amarelas, por vezes, com máculas castanhas. Estigma (2)3-fido. Aquênios pardo-claros, raro castanhos, obovóides, 1-1,5 x 0,8-1,2 mm, lenticulares, superfície com fileiras longitudinais de células retangulares bem evidentes, 2-costados, brevemente estipitado, ápice com um peque- no espessamento; estilopódio castanho-escuro, cônico comprimido lateralmente, 0,5-1 mm de comprimento.

Nome vulgar: junco.

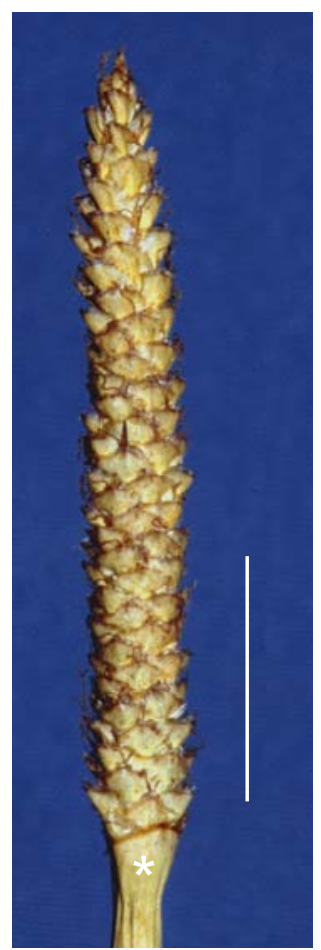

Figura 12. Eleocharis equisetoides (Elliott.) Torr. (Segadas-Vianna 4325). Espiga (*gluma inferior) (barra $=10 \mathrm{~mm}$ ).

Figure 12. Eleocharis equisetoides (Elliott.) Torr. (Segadas-Vianna 4325). Spike $\left({ }^{*}\right.$ lower glume $)($ scale bar $=10 \mathrm{~mm})$.

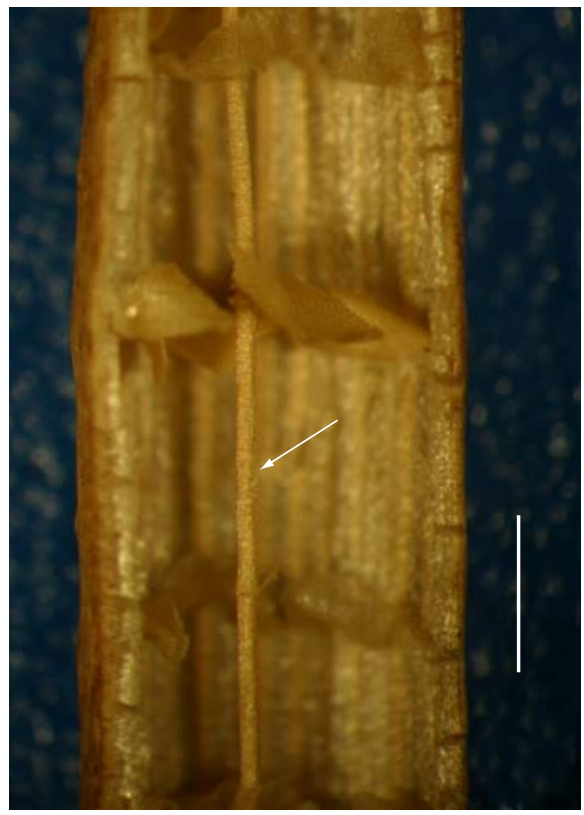

Figura 13. Eleocharis equisetoides (Elliott.) Torr. (Segadas-Vianna 4325). Corte longitudinal do colmo, com seta indicando o feixe vascular contínuo central (barra $=1 \mathrm{~mm})$.

Figure 13. Eleocharis equisetoides (Elliott.) Torr. (Segadas-Vianna 4325). Culm in longitudinal section, with an arrow indicating central continuous vascular bundle (scale bar $=1 \mathrm{~mm}$ ). 
Distribuição geográfica: AMÉRICA: Estados Unidos e Brasil (PB*, BA*, MG, RJ* e SP). * Novas ocorrências.

Floração: janeiro, março, junho e julho.

Frutificação: janeiro e junho.

Habitat: brejos dulcícolas e lagoas.

Material examinado: BRASIL: RIO DE JANEIRO: São João da Barra, 21 S 38', 41 W 03', cerca de 10 km da cidade, perto da bifurcação para Gurçaí, 23-III-1982, E. S. F. da Rocha et al. 876

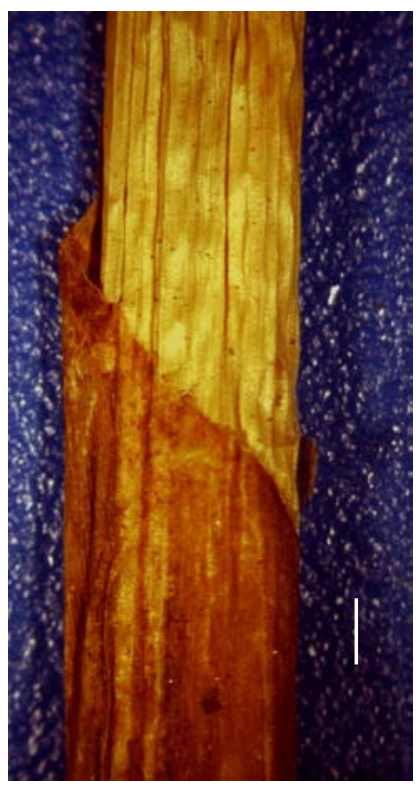

Figura 14. Eleocharis equisetoides (Elliott.) Torr. (Segadas-Vianna 4325). Ápice da bainha (barra $=1 \mathrm{~mm}$ ).

Figure 14. Eleocharis equisetoides (Elliott.) Torr. (Segadas-Vianna 4325). Sheath apex (scale bar $=1 \mathrm{~mm})$.

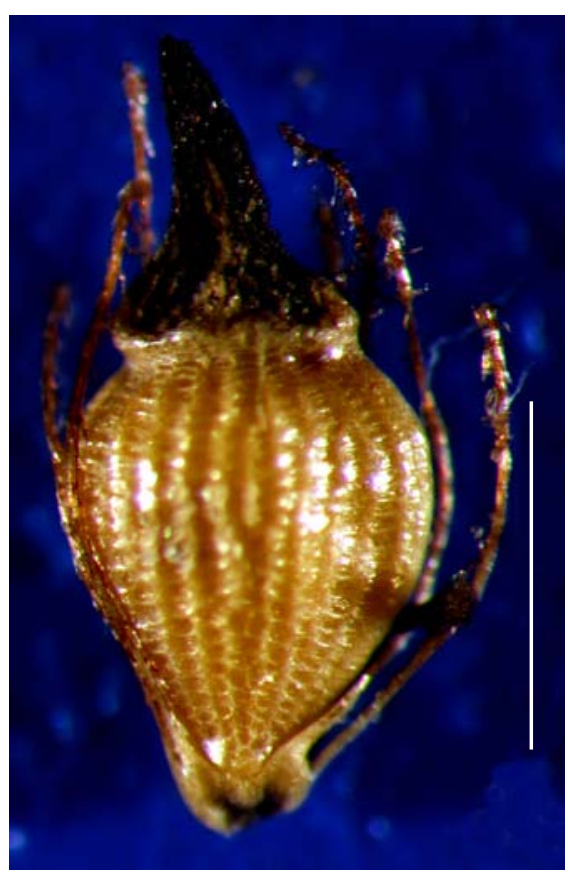

Figura 15. Eleocharis equisetoides (Elliott.) Torr. (Segadas-Vianna 4325). Aquênio (barra $=1 \mathrm{~mm}$ ).

Figure 15. Eleocharis equisetoides (Elliott.) Torr. (Segadas-Vianna 4325). Achene (scale bar $=1 \mathrm{~mm}$ ).
(GUA); Macaé, 22 S 22', 41 W 47', Lagoa de Cabiúnas, 7-I-1982, D. Araújo 4751 (GUA); Armação de Búzios, 22 S 44', 41 W 52', ao longo da estrada, 27/29-VII-1965, Segadas-Vianna 4325 (R).

Material adicional examinado: BRASIL: PARAÍBA: Baía da Traição, 06 S 41', 34 W 56', próximo à entrada da cidade, 20-VII2001, C. P. Bove et al. 888 (R); BAHIA: Ilhéus, 14 S 47', 39 W 02', Rodovia Olivença- Ilhéus, a 3 km depois de Olivença, 18-VI-1993, C. P. Bove \& W. Costa 121 (R).

Comentários: Eleocharis equisetoides, em coleções de herbário, apresenta-se com hábito muito semelhante a E. interstincta, para distinguí-las, faz-se necessário um corte longitudinal no colmo. $\mathrm{O}$ colmo de E. equisetoides apresenta em seu interior um feixe vascular contínuo no centro de um grande canal de ar; o colmo de E. interstincta não apresenta este feixe, apesar de possuir um grande canal de ar. Estas espécies diferem, ainda, por E. equisetoides apresentar colmo estriado longitudinalmente, uma gluma inferior e aquênio 2-costado com um pequeno espessamento no ápice, enquanto que E. interstincta apresenta colmos lisos, duas glumas inferiores e aquênio acostado com um breve colo no ápice.

A descrição feita por Torrey (1836) de E. equisetoides, para a América do Norte, confere com o material examinado neste trabalho, porém, este autor não faz nenhuma referência ao feixe vascular contínuo central encontrado no interior do colmo desta espécie. Dentre as espécies de Eleocharis examinadas, este caráter mostrou-se exclusivo de E. equisetoides.

\section{Eleocharis filiculmis Kunth, Enum. Pl. 2: 144. 1837. (Figuras 16-18)}

Ervas eretas, cespitosas, rizomatosas. Colmos 8-31 cm x 0,7$1,3 \mathrm{~mm}$ na base, pentangulares, quando secos achatados, inconspicuamente esponjosos, estriados longitudinalmente, sulcados, verdes. Bainhas membranáceas, castanho-avermelhadas na base, pardo-esverdeadas na região mediana, purpúreas próximo ao ápice, 2,5-3,5 cm

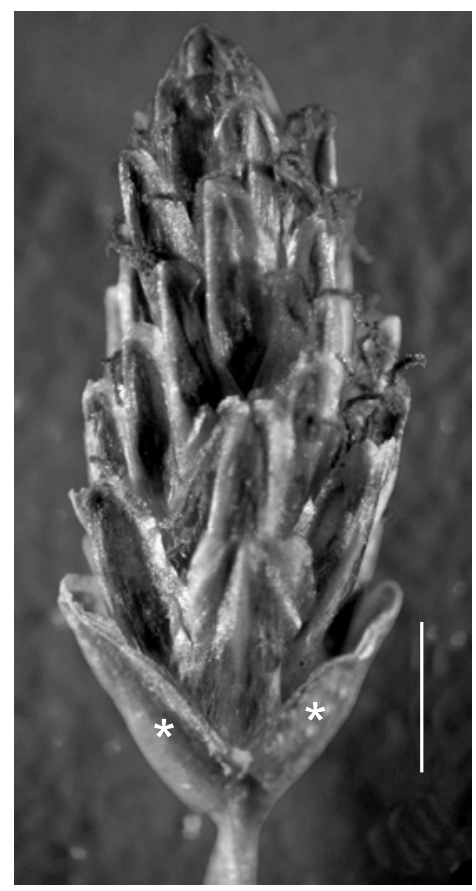

Figura 16. Eleocharis filiculmis Kunth (A. Gil et al. 27). Espiga (*glumas inferiores) (barra $=1 \mathrm{~mm}$ ).

Figure 16. Eleocharis filiculmis Kunth (A. Gil et al. 27). Spike (*lower glumes) (scale bar $=1 \mathrm{~mm})$. 


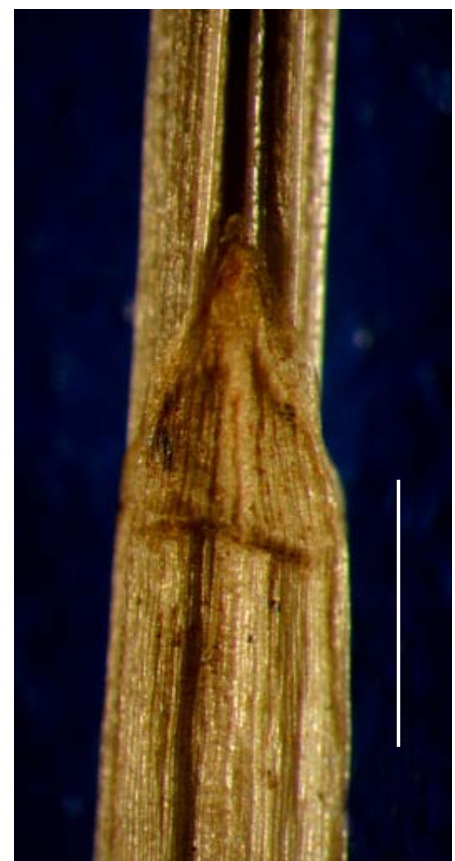

Figura 17. Eleocharis filiculmis Kunth (A. Gil et al. 27). Ápice da bainha (barra $=1 \mathrm{~mm})$.

Figure 17. Eleocharis filiculmis Kunth (A. Gil et al. 27). Sheath apex (scale bar $=1 \mathrm{~mm})$.

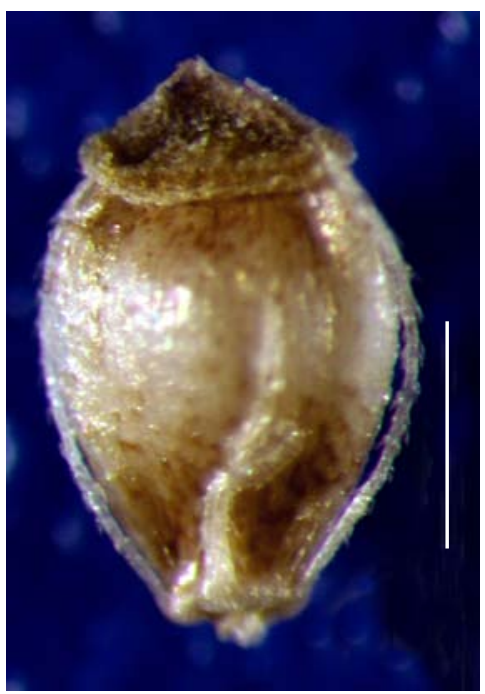

Figura 18. Eleocharis filiculmis Kunth (A. Gil et al 27). Aquênio (barra = $0,5 \mathrm{~mm})$.

Figure 18. Eleocharis filiculmis Kunth (A. Gil et al. 27). Achene (scale bar = $0.5 \mathrm{~mm})$.

de comprimento, sem apêndice hialino no ápice; ápice oblíquo, cuspidado, íntegro. Espigas multifloras, proliferação ausente, ovóides a elipsóides, 0,4-1,1 cm x 1,5-3 mm, agudas a obtusas, castanho a castanho-avermelhadas. Glumas espiraladas, carenadas, membranáceas, caducas, carena creme a parda, lados castanhos de 1/2 superior a totalidade, oval-lanceoladas, ápice emarginado, raro subagudo, margens hialinas, íntegras, nervuras longitudinais não proeminentes, 1,5-2,5 x 1-1,5 mm. Duas glumas inferiores, opostas, articuladas com o colmo, estéreis, carena verde, larga com nervura longitudinal central proeminente, por vezes, máculas castanho-avermelhadas beirando a região da carena; ambas com 1,5-2,5 x 1-2 mm, caducas, margem larga hialina e íntegra, ápice emarginado a obtuso. Cerdas perigoniais 4-6, alvas, 0,7-1 mm de comprimento. Estames 3, filetes hialinos a acastanhados, anteras brevemente apiculadas, amarelas a castanho. Estigma 3-fido. Aquênios alvos a amarelo-escuros, obovóides, 0,7-1 x 0,5-0,7 mm, trígonos, superfície levemente estriada e lustrosa, 3-costados, estípite ausente, ápice com um colo; estilopódio alvo a castanho-claro, piramidal, comprimido horizontalmente, menor que $0,5 \mathrm{~mm}$ de comprimento.

Nome vulgar: junco.

Distribuição geográfica: AMÉRICA: México, Cuba, República Dominicana, Belize, Guatemala, Honduras, El Salvador, Nicarágua, Costa Rica, Antilhas, Panamá, Trinidad, Venezuela, Colômbia, Guiana, Suriname, Brasil (RR, PI, PE, BA, MT, GO*, SP, SC e RS), Equador, Peru, Bolívia, Paraguai e Argentina. * Nova ocorrência.

Floração e frutificação: fevereiro, maio, julho, agosto, setembro e novembro.

Habitat: brejos e margem de rios.

Material examinado: BRASIL: RIO DE JANEIRO: Itatiaia, $22 \mathrm{~S}$ 29', 44 W 33', Faz. Aleluia, Rio Campo Belo, 15-VIII-2001, A. Gil et al. 27 (R); Rio de Janeiro, 22 S 54', 43 W 12', Recreio dos Bandeirantes, Pedra de Itaúna, 22-VII-1965, N. Santos et al. 5957 (R).

Material adicional examinado: BRASIL: GOIÁS: Britânia, 15 S 14', 51 W 09', Estrada Jussara - Britânia (via Jacilândia), a 78,2 km de Jussara, 12-XI-1999, C. P. Bove et al. 544 (R).

Comentários: esta espécie pode ser confundida com E. genicula$t a$, por terem as características dos colmos, bainhas e espigas bastante semelhantes, porém podem ser distintas através dos seus aquênios que em E. filiculmis são alvos a pardo-pálido e em E. geniculata são negros a negro-purpúreos. E. filiculmis também pode ser confundida com E. sellowiana pelo fato de apresentarem o hábito, a cor e a forma das espigas semelhantes, porém o ápice da bainha é cuspidado e não apresenta apêndice hialino em E. filiculmis e mucronado, com apêndice hialino em E. sellowiana. Outras características marcantes em E. filiculmis são o ápice emarginado das glumas e colmo pentangular quando hidratado.

6. Eleocharis flavescens (Poir.) Urb., Symb. Antill. 4(1):116. 1903. (Figuras 19-21)

\section{Scirpus flavescens Poir., Encycl. 6:756. 1805.}

Ervas eretas, cespitosas, estoloníferas. Colmos 4-32 cm x 0,51,0 $\mathrm{mm}$ na base, cilíndricos a elípticos, inconspicuamente esponjosos, estriados longitudinalmente, sulcos ausentes, verdes. Bainhas membranáceas, pardas a castanho-avermelhadas na base, pardas a verde-pálidas acima, ou ainda, toda verde ou purpúrea com 5 nervuras longitudinais verdes proeminentes, $1-4 \mathrm{~cm}$ de comprimento, apêndice hialino no ápice; ápice oblíquo a truncado, mucronado, íntegro. Espigas multifloras, proliferação ausente, ovóides a elipsóides, às vezes, subglobosas, 2-5 x 1,5-2,5 mm, agudas a obtusas, amareladas a pardo esverdeadas. Glumas espiraladas, carenadas, membranáceas, persistentes, verdes a pálido-esverdeadas na região da carena, lados às vezes com pequenas manchas avermelhadas ou cremes na metade superior, ovaladas a oblongas, ápice obtuso a agudo, margens hialinas a pardas, íntegras, apenas nervura longitudinal central proeminente, 2-2,5 x 1-1,5 mm. Duas glumas inferiores, articuladas com o colmo, estéreis, caducas, pardas com proeminentes carenas verdes clareando em direção a margem, 3-nervadas, internamente bem evidentes, 1,5-2 x 0,5-1 mm, margens hialinas, ás vezes, pardas, íntegras, ápice obtuso a subagudo. Cerdas perigoniais 7(8), cremes a pardas, 0,5-1 mm de comprimento. Estames 3, filetes hialinos a castanhopálidos, anteras brevemente apiculadas, as vezes apículo ausente, 


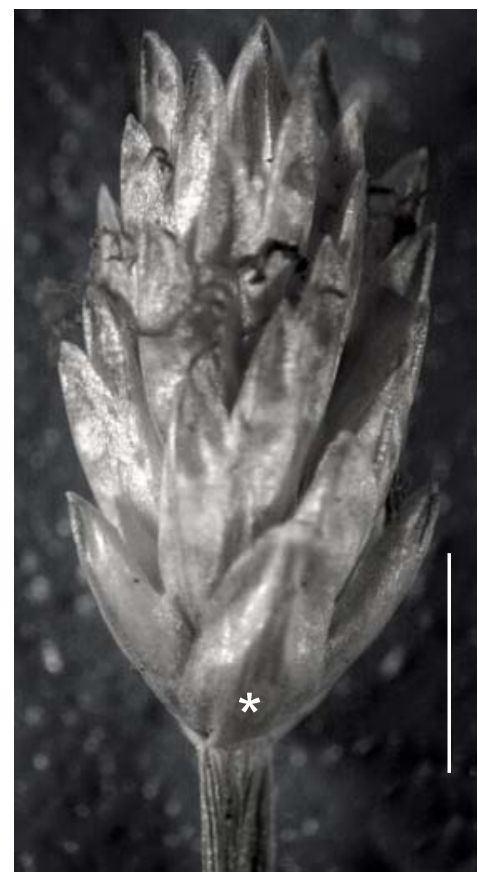

Figura 19. Eleocharis flavescens (Poir.) Urb. (A. Gil \& B. Figueira 139). Espiga (*uma das glumas inferiores) (barra $=1 \mathrm{~mm}$ ).

Figure 19. Eleocharis flavescens (Poir.) Urb. (A. Gil \& B. Figueira 139). Spike (*one of the lower glumes) (scale bar $=1 \mathrm{~mm})$.

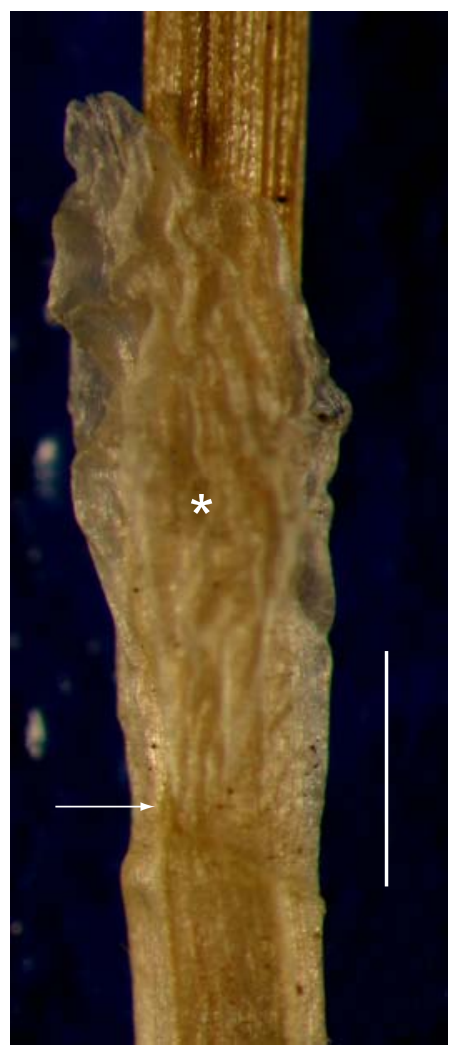

Figura 20. Eleocharis flavescens (Poir.) Urb. (A. Gil \& B. Figueira 139). Ápice da bainha com seta indicando o mucron (*apêndice hialino) (barra $=1 \mathrm{~mm})$.

Figure 20. Eleocharis flavescens (Poir.) Urb. (A. Gil \& B. Figueira 139). Sheath apex with an arrow indicating mucro (*hyaline appendage) (scale bar $=1 \mathrm{~mm})$.

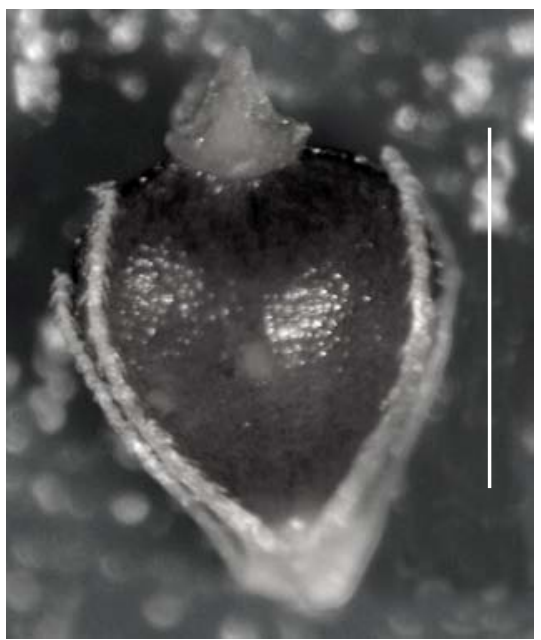

Figura 21. Eleocharis flavescens (Poir.) Urb. (A. Gil \& B. Figueira 139). Aquênio (barra $=0,5 \mathrm{~mm}$ ).

Figure 21. Eleocharis flavescens (Poir.) Urb. (A. Gil \& B. Figueira 139). Achene (scale bar $=0.5 \mathrm{~mm}$ ).

amareladas. Estigma 2-fido. Aquênios castanho-claros a escuros, obovóides a suborbiculares, 0,5-1 x 0,5 mm, lenticulares, superfície reticulada e lustrosa, 2-costados, às vezes, inconspicuamente, costados, estipitados, ápice com um colo; estilopódio verde a pardo-pálido, esponjoso, cônico horizontalmente comprimido (discóide), menor que $0,5 \mathrm{~mm}$ de comprimento.

Nome vulgar: junco.

Distribuição geográfica: AMÉRICA: Estados Unidos, México, Bahamas, Cuba, Jamaica, Porto Rico, Guatemala, Honduras, Nicarágua, Antilhas, Costa Rica, Colômbia, Venezuela, Guiana, Guiana Francesa, Brasil (RR, PA, PB, PE, BA, MG, RJ, SP e SC), Equador, Paraguai, Argentina e Uruguai.

Floração e frutificação: janeiro, fevereiro, março, julho, setembro, novembro e dezembro.

Habitat: alagados adjacentes a rios, brejos herbáceos, córregos, interior de restingas em baixios alagáveis e terrenos encharcados.

Material examinado: BRASIL: RIO DE JANEIRO: Campos dos Goytacazes, 21 S 45', 41 W 19', Granja Bom Sucesso, II-1918, A. Sampaio 2843 (R); Nova Friburgo, 22 S 16', 42 W 31', Caminho da cascata do Pinel, 6-IX-1986, J. C. Siqueira \& Helênio 2119 (FCAB); s/município, Serra dos Órgãos, I-1916, V. Luetzelburg 12.222 (R43212); Itatiaia, 22 S 29', 44 W 33', Faz. da Serra, VII-1959, H. E. Strang. 123 (R); Paulo de Frontin, 22 S 32', 43 W 40', 26 km da Via Dutra - sentido Mendes, Caluje Hotel Fazenda, Vale do Sol, 26-I2003, A. Gil \& B. Figueira 139 (R); Casimiro de Abreu, Barra de São João, 22 S 35', 41 W 59', 6-XII-1948, L. de C. Faria \& A. L. de Carvalho s/n (R-114680); Idem, ibidem, $1 \mathrm{~km}$ norte da Aldeia da Barra de São João, 3-IX-1953, Segadas-Vianna et al. Restinga I-7 (R); Silva Jardim, 22 S 39', 42 W 23', Poço d'Anta, 17-XI-1976, M. C. Vianna et al. 909 (GUA); Rio Bonito, 22 S 42', 42 W 36', Braçanã, Faz. das Cachoeiras, 4-IX-1977, P. Laclette 350 (R); Itaboraí, 22 S 44', 42 W 51', Estrada do Jardim Bom Retiro, 17-XII-1976, D. Araújo 1447 (GUA); Maricá, 22 S 55', 42 W 49’, Barra de Maricá, 27-XI-1989, A. Souza 2844 (R); Idem, cerca de $2 \mathrm{~km}$ da entrada da A.P.A. de Maricá, 10-II-2000, C. B. Moreira et al. 75 (R); Idem, Ibdem, 3-XI2002, A. Gil \& B. Figueira 30 (R); Rio de Janeiro, 22 S 54', 43 W 12', Pico da Tijuca, 24-I-1932, A. C. Brade 11310 (R); Idem, Gávea, VII1916, A. Frazão s/n (RB-7534); Idem, Jacarepaguá, Rio das Pedras, Estrada Engenheiro Souza Filho entre os nos 21 e 65, 14-VII-1981, M. B. Casari et al. 575 (GUA); Idem, Recreio dos Bandeirantes, 
Lagoa das Taxas, 23-XI-1981, M. B. Casari \& C. Pape 621 (GUA); Angra dos Reis, 23 S 00', 44 W 19', XI-1950, Segadas-Vianna 3061 (R); Idem, próximo ao rio Bracuhy, 17-IX-1980, D. Araújo \& N. C. Maciel 4001 (GUA); Idem, Ilha Grande, 23 S 08', 44 W 10', Praia do Sul, 2-XII-1980, D. Araújo et al. 4134 (GUA); Idem, ibidem, Reserva Biológica Estadual da Praia do Sul, Lagoa do Leste, 30-III-1993, D. Araújo 9790 (GUA); Idem, ibidem, Praia da Parnaióca, 5-III-2002, A. A. M. de Barros et al. 1445 (HB); Idem, ibidem, perto da Mãe D’água, 4-III-2002, C. C. Zysko et al. 200 (HB).

Comentários: Eleocharis flavescens mostrou-se bastante semelhante em herbário a E. sellowiana, sendo separada, principalmente, pela cor das espigas, superfície e cor dos aquênios e forma da estilopódio. E. flavescens apresenta espigas amareladas a pardo esverdeadas, aquênios, preferencialmente, castanho-escuros; estilopódio cônico horizontalmente comprimido (discóide), enquanto E. sellowiana apresenta espigas pardo-esverdeadas na base e castanho-avermelhadas no ápice, às vezes castanho-claras, aquênios, quase sempre oliváceos; estilopódio cônico comprimido lateralmente.

\section{Eleocharis geniculata (L.) Roem. \& Schult., Syst. Veg.}

2:150. 1817. (Figuras 22-24)

\section{Scirpus geniculatus L., Sp. Pl. 1:48. 1753.}

Ervas eretas, cespitosas, rizomatosas. Colmos $4-55 \mathrm{~cm} \mathrm{x}$ 0,5-1,5 $\mathrm{mm}$ na base, cilíndricos a achatados, inconspicuamente esponjosos, estriados longitudinalmente, sulcados ou não, verdes. Bainhas subcoriáceas, castanhas a castanho-violáceas na base, pardas a castanho-escuras na região mediana, verdes a castanhas próximo ao ápice, 1-3,5 cm de comprimento, sem apêndice hialino no ápice; ápice oblíquo, cuspidado a apiculado, íntegro. Espigas multifloras, proliferação ausente, ovóides a globosas, $0,2-1 \mathrm{~cm} \times 1,5-5 \mathrm{~mm}$, obtusas, raro agudas, ocres a castanhas. Glumas espiraladas, carenadas, membranáceas, caducas, região da carena verde ou parda, lados castanho-avermelhados de $1 / 4$ da gluma até toda sua extensão, às vezes lados pardos ou hialinos, elípticas a orbiculares, ápice obtuso, margem escariosa e hialina, apenas nervura longitudinal central proeminente, 1,5-2 x 1-1,5 mm. Duas a três (raro quatro) glumas inferiores, articuladas com o colmo, estéreis, caducas, pardas, às vezes, com máculas castanhas, com carenas pardas a verdes bastante proeminentes, 3-nervadas, internamente, bem evidentes, 1-2,2 x 1-1,5 mm, margens



Figura 22. Eleocharis geniculata (L.) Roem. \& Schult. (A. G. Andrade s/nº, R-200990). Espiga (*glumas inferiores) (barra = $1 \mathrm{~mm}$ ).

Figure 22. Eleocharis geniculata (L.) Roem. \& Schult. (A. G. Andrade s/nº, R-200990). Spike (*lower glumes) (scale bar $=1 \mathrm{~mm}$ ). hialinas, ás vezes, pardas, íntegras, ápice obtuso. Cerdas perigoniais 7 , pardo-pálidas à castanhas, 1-1,5 mm de comprimento, ás vezes vestigiais ou ausentes. Estames 3, filetes hialinos, anteras brevemente apiculadas, castanho-amareladas. Estigma 2-fido. Aquênios negros a negro-purpúreos, obovóides a suborbiculares, 0,5-1 × 0,5-0,8 mm, lenticulares, superfície lisa e lustrosa, 2-costados, estipitados, ápice com um colo; estilopódio pardo a castanho-claro, esponjoso, cônico horizontalmente comprimido (discóide), com margem esbranquiçada, menor que $0,5 \mathrm{~mm}$ de comprimento.

Nomes vulgares: junco, tiririca e junco-popoca.

Distribuição geográfica: AMÉRICA: Estados Unidos, Bermudas, México, Bahamas, Ilhas Virgens, Cuba, República Dominicana,

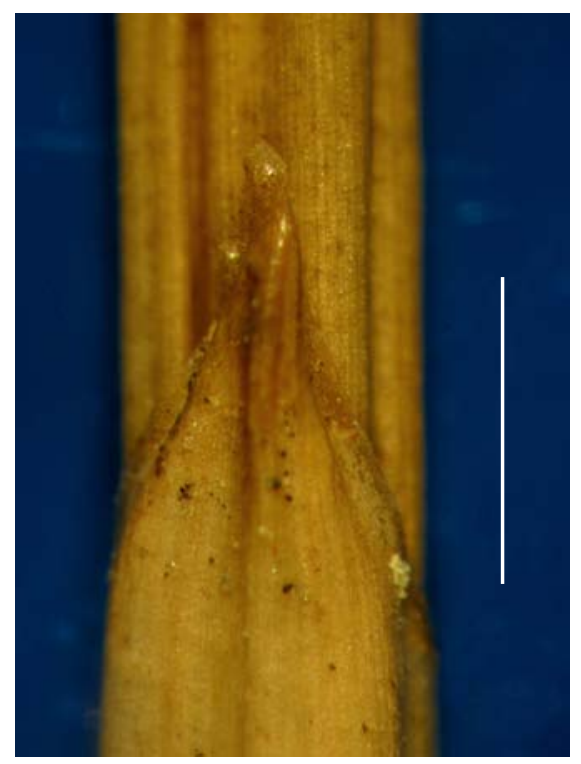

Figura 23. Eleocharis geniculata (L.) Roem. \& Schult. (A. G. Andrade s/nº, $\mathrm{R}-200990)$. Ápice da bainha (barra $=1 \mathrm{~mm}$ ).

Figure 23. Eleocharis geniculata (L.) Roem. \& Schult. (A. G. Andrade s/nº, $\mathrm{R}-200990)$. Sheath apex (scale bar $=1 \mathrm{~mm})$.

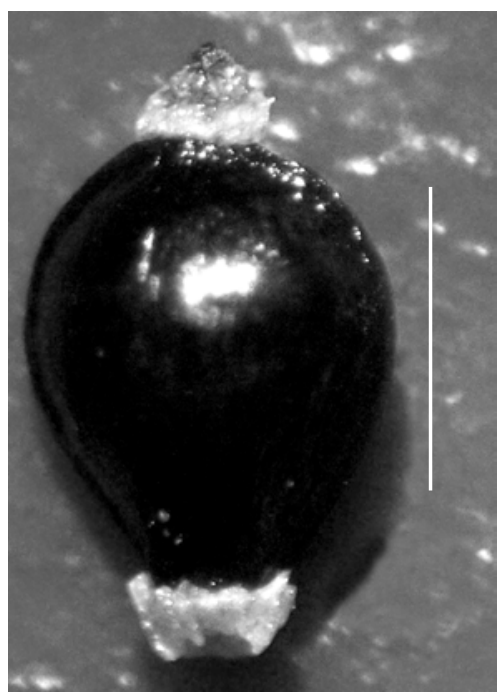

Figura 24. Eleocharis geniculata (L.) Roem. \& Schult. (A. G. Andrade s/nº, $\mathrm{R}-200990)$. Aquênio (barra $=0,5 \mathrm{~mm}$ ).

Figure 24. Eleocharis geniculata (L.) Roem. \& Schult. (A. G. Andrade s/nº, $\mathrm{R}-200990$ ). Achene (scale bar = 0,5 mm). 
Haiti, Jamaica, Porto Rico, Antilhas, Belize, Guatemala, Honduras, El Salvador, Nicarágua, Costa Rica, Panamá, Venezuela, Colômbia, Guiana, Guiana Francesa, Brasil (PA, MA, PI, CE, PB, PE, AL, SE, BA, MT, GO, MS, MG, ES, RJ, SP, SC e RS), Equador, Peru, Bolívia, Paraguai, Argentina e Uruguai. ÁFRICA: Senegal, Camarões, Gabão e Tanzânia. ÁSIA: Japão, Índia e Filipinas. OCEANIA: Ilhas Fiji e Austrália.

\section{Floração e frutificação: o ano inteiro.}

Habitat: alagados, brejos entre dunas, canais temporários beirando estradas, lagoas e lagunas.

Material examinado: BRASIL: RIO DE JANEIRO: São João da Barra, Atafona, 21 S 38', 41 W 03', 20-VI-1941, N. Santos \& F. de Lauro s/n (R-44019); Campos dos Goytacazes, 21 S 45', 41 W 19', Santo Amaro de Campos, nas lagoas próximo ao Farol de São Tomé, 30-V-1953, Segadas-Vianna et al. Restinga I-432 (R); Quissamã, 22 S 06', 41 W 28', a 30 km da Prefeitura, Parque Nacional da Restinga de Jurubatiba, 12-XI-2002, A. Gil et al. 49 (R); Idem, a 33 km da Prefeitura, Parque Nacional da Restinga de Jurubatiba, 12-XI-2002, A. Gil et al. 51 (R); Idem, a 27 km da Prefeitura, Parque Nacional da Restinga de Jurubatiba, Amarra-boi, 13-XI-2002, A. Gil et al. 53 (R); Carapebus, 22 S 11', 41 W 39', Lagoa de Carapebus, margem esquerda, 7-IV-1983, D. Araújo \& M. B. Casari 5554 (GUA); Idem, $2 \mathrm{~km}$ à frente da área de pólen e biologia floral, 18-X-1995, I. M. Silva et al. 249 (R); Idem, Restinga de Carapebus, transecto na área de estudos de Palinologia e Biologia Floral, 12-IX-1995, V. L. C. Martins et al.150 (R); Idem, ibidem, as margens da lagoa Paulista e a $500 \mathrm{~m}$ da praia, 27-II-1996, A. S. Oliveira et al. 3785 (R); Idem, Parque Nacional da Restinga de Jurubatiba, Lagoa Paulista, 21-X-2003, C. P. Bove et al. 1274 (R); Idem, ibidem, Lagoa Paulista, 21-X-2003, C. P. Bove et al. 1275 (R); Idem, ibidem, Lagoa Encantada, 26-VI1996, V. L. C. Martins et al. 319 (R); Idem, próximo a cerca da Faz. Retiro à caminho do alagado, 28-X-1996, M. C. de Oliveira et al. 389 (R); Idem, Praia de Carapebus, 1-X-1999, C. P. Bove et al. 460 (R); Macaé, 22 S 22', 41 W 47', Lagoa Comprida, 6-IV-1983, M. B. Casari \& D. S. D. Araújo 988 (GUA); Idem, Lagoa de Imboassica, 9-II-1981, D. Araújo \& N. C. Maciel 4213 (GUA); Rio das Ostras, 22 S 31', 41 W 56', no Trevo bem Próximo à Praia, 23-XI-2000, C. P. Bove et al. 775 (R); Teresópolis, 22 S 24', 42 W 57', Serra dos Órgãos, 4-XI-1971, A. G. Andrade s/n (R); Casimiro de Abreu, Barra de São João, 22 S 35', 41 W 59', Praia da Barra de São João, 27/29VIII-1965, Segadas-Vianna 4366 (R); Armação de Búzios, 22 S 44', 41 W 52', Estrada Búzios-Cabo Frio a $500 \mathrm{~m}$ do trevo de Búzios, 1-X-1999, C. P. Bove \& W. Costa 872 (R); São Pedro da Aldeia, 22 S 50', 42 W 06', alagado próximo a rua do Fogo e RJ-106, 5-II-1983, H. Q. B. Fernandes 704 (GUA); Cabo Frio, 22 S 52', 42 W 01', dunas do Peró, próximo a estrada, 12-V-1982, D. Araújo \& N. C. Maciel 5065 (GUA); Idem, Estrada entre Lagoa de Araruama e Estrada Cabo Frio - Arraial do Cabo, 16-VIII-1953, Segadas-Vianna et al. Restinga I-853 (R); Idem, ibidem, 16-VIII-1953, Segadas-Vianna et al. Restinga I-869 (R); Araruama, 22 S 52', 42 W 20', 9-IX-1950, Segadas-Vianna 3541 (R); Idem, Praia do Sossego, 9-X-1999, C. B. Moreira 58 (R); Idem, ibidem, 10-II-2000, A. Gil et al. 12 (R); Arraial do Cabo, 22 S 57', 42 W 01', Praia do Pontal, II/III-1951, Segadas-Vianna 4076 (R); Idem, ibidem, II/III-1951, L. E. M. Filho 1141 (R); Idem, ibidem, II/III-1951, L. E. M. Filho 1144 (R); Idem, ibidem, 17-IV-1952, L. B. Smith 6557 (R); Idem, ibidem, V-1953, Segadas-Vianna et al. Restinga I-50 (R); Idem, ibidem, 24-IV-1953, Segadas-Vianna et al. Restinga I-43 (R); Idem, ibidem, 7-V-1953, Segadas-Vianna et al. Restinga I-42 (R); Idem, 24-V-1953, Segadas-Vianna et al. Restinga I-332 (R); Idem, ibidem, 26-V-1968, Segadas-Vianna 4661 (R); Saquarema, 22 S 55', 42 W 30', Praia do Sossego, 9-X-1999, C. B. Moreira 58 (R); Rio de Janeiro, 22 S 54', 43 W 12', Praia da Gávea, VII-1916, A. Frazão s/n (RB); Idem,
Gávea, IX-1916, A. Frazão s/n (RB); Idem, Barra da Tijuca, Jardim Oceânico, 16-I-1944, M. H. Valle 103 (R); Idem, Jacarepaguá, Br-6, 26-IX-1964, A. Castellanos 25620 (GUA); Idem, ibidem, Br-6, 26IX-1964, A. Castellanos 25647 (GUA); Idem, Lagoa de Jacarepaguá, 16-VIII-1931, A.C. Brade 10975 (R); Idem, Restinga de Jacarepaguá, 10-IX-1958, E. Pereira et al. 4178 (HB); Idem, Gruta da Imprensa, 19-II-1960, A. P. Duarte 5184 (HB); Idem, Av. Niemeyer, 29-VI1922, Freire \& Vidal s/n (R-49182); Idem, ibidem, 5-V-1929, A. C. Brade s/n (R-20134); Idem, ibidem, XI-1936, A. C. Brade 15494 (R); Idem, Lagoa de Marapendí, margem Norte, 5-IX-1965, SegadasVianna 4375 (R); Idem, ibidem, 5-IX-1965, Segadas-Vianna 4373 (R); Idem, Baixada de Jacarepaguá, a beira da Lagoa de Marapendí, 9-IV-1976, D. Araújo 1080 (GUA); Idem, Recreio dos Bandeirantes, Itapeba, 16-VIII-1967, A. Castellanos 26705 (HB); Idem, ibidem, Restinga de Itapeba, Estrada Rio-Santos junto a entrada do campo da FAB, 17-I-1967, Segadas-Vianna 4463/ 4464 (R); Idem, Praia de Grumari, Próximo à Guaratiba, 11-IV-1952, L. B. Smith 6502 (R); Idem, Ilha da Marambaia, Praia Grande, 16-I-1986, C. M. Rizzini 305 (RFA); Idem, s/data, J. G. Kuhl s/n (RB-139798); Idem, 12-III1967, H. Strong 986 \& A. Castellanos 26288 (HB); Angra dos Reis, Ilha Grande, 23 S 08', 44 W 10', Praia da Parnaióca, 5-III-2002, A. A. M. de Barros et al. 1444 (HB).

Comentários: trata-se da espécie de Eleocharis mais coletada no Estado, sendo provavelmente a mais abundante. Caracteriza-se, por apresentar espigas, preferencialmente, globosas e obtusas, ápice da bainha oblíquo, cuspidado a apiculado e íntegro, aquênios negros a negro-purpúreos, esta última característica é a que mais facilmente a distingue de E. filiculmis com seus aquênios alvos a pardo-pálidos (vide comentários em E. filiculmis - loc. cit.)

Eleocharis geniculata apresenta grande tolerância à salinidade, sendo encontrada, muitas vezes, em ambientes hipersalinos. Aparece no Estado, muitas vezes, em comunidade com E. mutata e ainda, mostra grande variação do tamanho de seus colmos, que vão diminuindo, à medida que a disponibilidade de água vai reduzindo.

As ráquis das espigas de E. geniculata podem chegar a mais de $1 \mathrm{~cm}$ de comprimento, pois elas crescem em direção ao ápice produzindo novas flores ao mesmo tempo em que suas glumas basais caem com os aquênios maduros, por isso, podem ser encontradas espigas com grande parte da ráquis sem glumas.

8. Eleocharis interstincta (Vahl) Roem. \& Schult., Syst. Veg. 2:149. 1817. (Figuras 25-27)

\section{Scirpus interstinctus Vahl, Enum. Pl. 2:251. 1805.}

Ervas eretas, cespitosas, estoloníferas. Colmos 30-106 cm x 4-8 mm na base, cilíndricos, com um grande canal de ar central, feixe vascular contínuo no centro ausente, regularmente septados, não nodulosos, septos transversais evidentes, lisos, sulcos ausentes, verdes. Bainhas membranáceas, castanho-avermelhadas a castanho-purpúreas, 14,5-28 cm de comprimento, sem apêndice hialino no ápice; ápice oblíquo, acuminado, íntegro. Espigas multifloras, proliferação ausente, cilíndricas, 1,5-4,5 cm x 4-6 mm, subagudas, verdes a amareladas. Glumas espiraladas, não carenadas, subcartilaginosas na parte central, principalmente na parte superior endurecida, membranáceas nas margens, caducas, de verdes a pardas, internamente pontuadas de castanho, às vezes, com uma faixa castanho-escura beirando internamente a margem apical, obovadas a ovaladas, ápice obtuso, margem hialina e escariosa, nervuras longitudinais proeminentes, 4,5$5,5 \times 3,5-4 \mathrm{~mm}$. Duas glumas inferiores, a mais externa englobando toda, ou quase toda, base da espiga, contínua com o colmo, estéril, poucas vezes fértil, 5,5-7 mm de comprimento e 3,5-5 mm diâmetro, a mais interna oposta à externa, articulada com o colmo, fértil, 5,5-7 
x 3,5-4,5 mm, persistentes, verde-amareladas a verde-pálidas, margens hialinas e escariosas, ápice obtuso. Cerdas perigoniais (6)7(8), pardas, 3-4 mm de comprimento. Estames 3, filetes hialinos, anteras apiculadas, amarelas com máculas castanhas alongadas. Estigma (2)3-fido. Aquênios amarelo-esverdeados a amarelo-acastanhados,

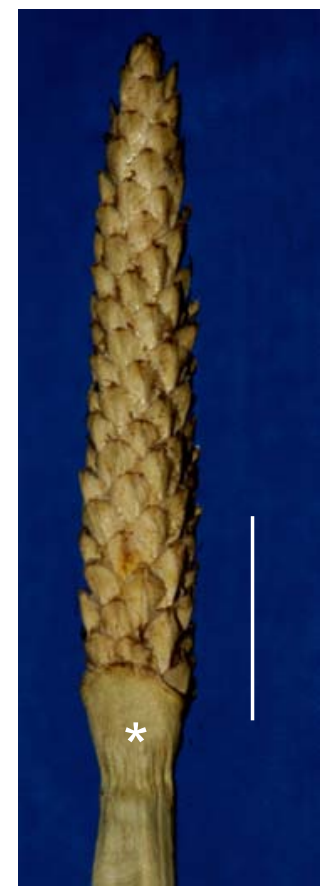

Figura 25. Eleocharis interstincta (Vahl) Roem. \& Schult. (A. Gil et al. 43). Espiga (*gluma inferior externa) (barra $=10 \mathrm{~mm}$ ).

Figure 25. Eleocharis interstincta (Vahl) Roem. \& Schult. (A. Gil et al. 43). Spike (*external lower glume) (scale bar $=10 \mathrm{~mm}$ ).

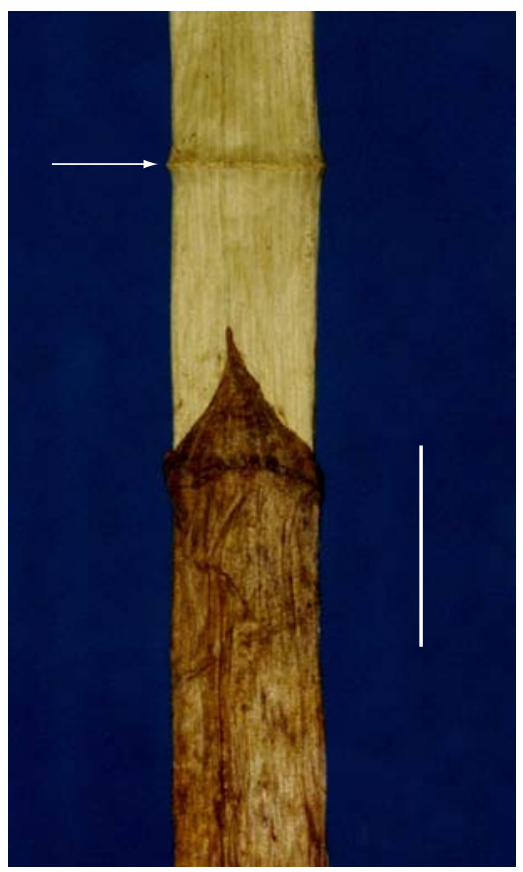

Figura 26. Eleocharis interstincta (Vahl) Roem. \& Schult. (A. Gil et al. 43). Ápice da bainha com seta indicando um septo transversal (barra $=10 \mathrm{~mm}$ ).

Figure 26. Eleocharis interstincta (Vahl) Roem. \& Schult. (A. Gil et al. 43). Sheath apex with an arrow indicating a transversal septum (scale bar $=10 \mathrm{~mm}$ ). às vezes amarelos com manchas castanhas, obovóides, 1,5-2 x 1$1,5 \mathrm{~mm}$, lenticulares, superfície com fileiras longitudinais de células retangulares, por vezes hexagonais, acostado, brevemente estipitado, ápice com um breve colo; estilopódio amarelo a castanho, cônico comprimido lateralmente, $1 \mathrm{~mm}$ de comprimento.

Nomes vulgares: junco, junquinho, taboinha e cebolinha.

Distribuição geográfica: AMÉRICA: Estados Unidos, Bermudas, México, Bahamas, Cuba, Haiti, Jamaica, Porto Rico, Antilhas, Belize, Guatemala, Honduras, Nicarágua, Costa Rica, Panamá, Colômbia, Venezuela, Trinidad, Guiana, Suriname, Brasil (RR, AC, PA, MA, CE, PB, PE, BA, MT, GO*, MG, MS, ES, RJ, SP, PR, SC e RS), Equador, Peru, Bolívia e Paraguai. ÁFRICA: África do Sul. * Nova ocorrência.

Floração e frutificação: janeiro, fevereiro, março, abril, maio, junho, julho, outubro, novembro e dezembro.

Habitat: brejos em restinga, canais, lagos e lagoas.

Material examinado: BRASIL: RIO DE JANEIRO: Campos dos Goytacazes, 21 S 45', 41 W 19', Granja Bom Sucesso, XII1917, A. J. de Sampaio 2759 (R); Idem, Lagoa Feia, Canal da Flecha onde sai da lagoa, na margem de um pasto, 12-VIII-1978, D. Araújo \& N. C. Maciel 2124 (GUA); Idem, ibidem, Canto do Toco, 27-XI-1979, D. Araújo \& N. C. Maciel 3448 (GUA); Idem, ibidem, Ponta de Ponta Grossa dos Fidalgos, 10-III-1981, M. B. Casari 471 (GUA); Idem, ibidem, próximo ao porto de Ponta Grossa, 15-XII1981, M. B. Casari 629 \& E. de S. F. da Rocha 719 (GUA); Idem, Lagoa Limpa, 30-III-1981, M. B. Casari et al. 505 (GUA); Idem, alagado entre o solar da Baronesa e Lagoa das Pedras, 9-III-1983, M. B. Casari 934 \& D. S. Pedrosa 833 (GUA); Quissamã, 22 S 06', 41 W 28', Lado direito da ponte do Imbiú, a $13 \mathrm{~km}$ da Prefeitura e a $8 \mathrm{~km}$ do trevo sentido praia de João Francisco, 11-XI-2002, A. Gil et al. 43 (R); Macaé, 22 S 22', 41 W 47', entre Lagoa Comprida e Carapebus, 6-IV-1983, D. Araújo \& M. B. Casari 5549 (GUA); Idem, Lagoa de Cabiúnas, 7-I-1982, D. Araújo 4750 (GUA); Idem, ibidem, margem direita, 5-IV-1983, D. Araújo \& M. B. Casari 5494 (GUA); Magé, 22 S 39', 43 W 02', Antiga Fazenda da Fábrica de Papel (Faz.

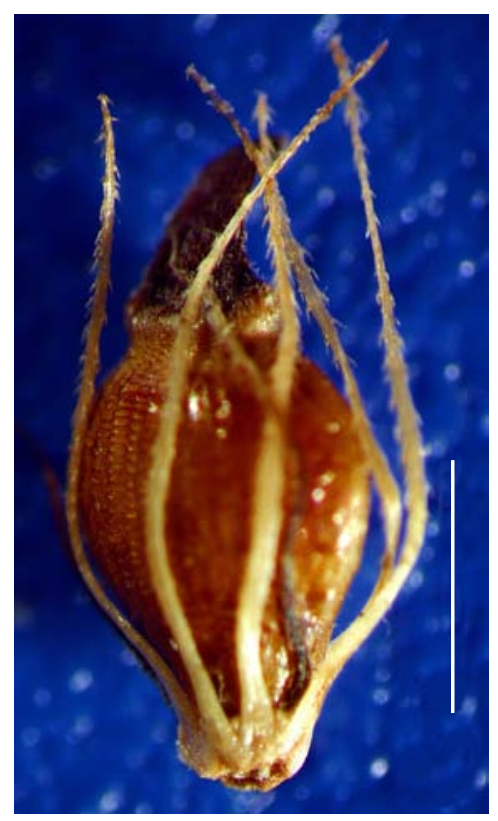

Figura 27. Eleocharis interstincta (Vahl) Roem. \& Schult. (A. Gil et al. 43). Aquênio (barra $=1 \mathrm{~mm}$ ).

Figure 27. Eleocharis interstincta (Vahl) Roem. \& Schult. (A. Gil et al. 43). Achene (scale bar $=1 \mathrm{~mm})$. 
Pedra Oca), próximo ao Rio do Bananal, 25-X-1982, E. S. F. da Rocha et al. 983 (GUA); Idem, Campo dos Escoteiros, 28-VI-2001, C. P. Bove et al. 866 (R); Silva Jardim, 22 S 39', 42 W 23', Estrada para Gaviões, ca. $12 \mathrm{~km}$ de Silva Jardim, 19-II-2003, C. P. Bove \& W. Costa 1104 (R); Araruama, 22 S 52', 42 W 20', Engenho Grande, Rua Transversal à Estrada do Engenho Grande, 21-IV-1999, C. B. Moreira et al. 46 (R); Arraial do Cabo, 22 S 57', 42 W 01', Praia do Pontal, 17-IV-1952, L. B. Smith 6558 (R); Saquarema, 22 S 55', 42 W 30', Bonsucesso, Estrada Antiga a 5 km de Bacaxá, 10-II-2000, C. B. Moreira et al. 83 (R); Maricá, 22 S 55', 42 W 49', Restinga de Maricá, brejo de Itaipuaçu, 23-V-1988, A. A. M. de Barros 342 \& K. Tanizaki 187 (RFA); Idem, ibidem, 3-II-1999, C. P. Bove et al. 412 (R); Idem, Inoã, km 11, após o trevo de Maria Paula, 10-II-2000, A. Gil et al. 02 (R); Idem, Itaipuaçu, próximo à Rua 1, 12-II-2000, R. Anjos \& L. Borré 27 (R); Duque de Caxias, 22 S 47', 43 W 18', Pilar, Estrada Rio-Petrópolis km 26, 14-II-1940, B. Lutz 1587 (R); Idem, 12-VII-1973, C. R. Campelo s/n (R-201857); Idem, Xerém, comunidade Lamarão, sítio das Andorinhas, 26-IV-2003, L. G. S. M. \& José Luis S. P. 434a (R); Rio de Janeiro, 22 S 54', 43 W 12', Pavuna, Baixada Fluminense, Estrada Rio-Petrópolis km 24, Grande brejo da Pavuna, s/coletor s/n (R-197538); Idem, Recreio dos Bandeirantes, lagoa do Croton, 13-VI-1968, J. D'Arc 39 (R); Mangaratiba, 22 S 57', 44 W 02', km 38 da Br-101 (Rio-Santos), altura de Porto Saí, 9-XII-1990, H. F. Martins 1886 (GUA).

Material adicional examinado: BRASIL: GOIÁS: Britânia, 15 S 14', 51 W 09', Estrada Jussara - Britânia (via Jacilândia) a 58,9 km de Jussara, 12-XI-1999, C. P. Bove et al. 552 (R).

Comentários: Eleocharis interstincta apresenta-se bastante semelhante a $E$. equisetoides, diferindo, principalmente, pela ausência de um feixe vascular no grande canal de ar central de seu colmo (vide comentários em E. equisetoides - loc. cit.). É a maior e mais robusta espécie de Eleocharis encontrada no estado do Rio de Janeiro, ocorrendo, freqüentemente, em locais com abundância de água, característica esta também evidenciada por Faria (1998) para o estado de São Paulo e Trevisan (2005) para o estado do Rio Grande do Sul.

\section{Eleocharis maculosa (Vahl) Roem. \& Schult., Syst. Veg. 2:154. 1817. (Figuras 28-30) Scirpus maculosus Vahl, Enum. Pl. 2:247. 1805.}

Ervas eretas, cespitosas, estoloníferas. Colmos 6-91,5 cm x 0,81,5 mm na base, subcilíndricos a elípticos, esponjosos, estriados longitudinalmente, sulcados, verdes lustrosos, pontuados de alvo a castanho. Bainhas membranáceas, púrpura ou creme na base, avermelhadas na região mediana, pardo-esverdeadas próximo ao ápice, ou ainda, toda purpúreas com 5 nervuras verdes proeminentes, 1-6 cm de comprimento, apêndice hialino no ápice; ápice oblíquo a truncado, mucronado, íntegro. Espigas multifloras, proliferação ausente, ovóides a elipsóides, 0,5-1,2 cm x 2-4,5 mm, agudas, às vezes obtusas, castanho-avermelhadas a castanho-escuras, às vezes púrpuras, outras vezes ocráceas. Glumas espiraladas, carenadas, membranáceas, caducas, verdes na carena, lados com manchas castanho-avermelhadas de metade superior da gluma até toda sua extensão, ovaladas, por vezes oblongas ou elípticas, ápice obtuso, às vezes subagudo, margens hialinas e íntegras, 2,5-3,5 x 1-1,5 mm. Duas glumas inferiores, uma mais externa, contínua com o colmo, às vezes articulada, $1-2 \times 1-1,5 \mathrm{~mm}$, outra mais interna sempre articulada, 1-1,5 x 1-1,3 mm, estéreis, caducas, verdes na carena, com carenas largas, 3-nervadas, internamente, bem evidentes, manchas castanhas beirando as grandes margens hialinas e escariosas, ápice emarginado a obtuso. Cerdas perigoniais 8(9), castanhas, 0,5-1 mm de comprimento. Estames 3, filetes hialinos, as vezes acastanhados

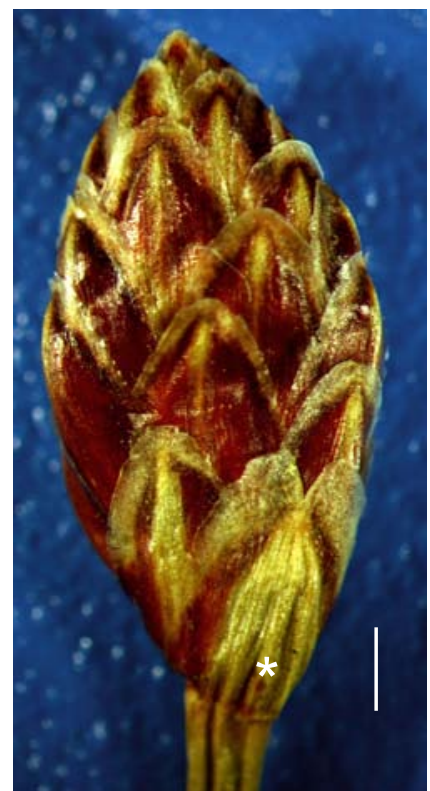

Figura 28. Eleocharis maculosa (Vahl) Roem. \& Schult. (B. Lutz 1570). Espiga (*uma das glumas inferiores) (barra $=1 \mathrm{~mm}$ ).

Figure 28. Eleocharis maculosa (Vahl) Roem. \& Schult. (B. Lutz 1570). Spike (*one of the lower glumes) (scale bar $=1 \mathrm{~mm}$ ).

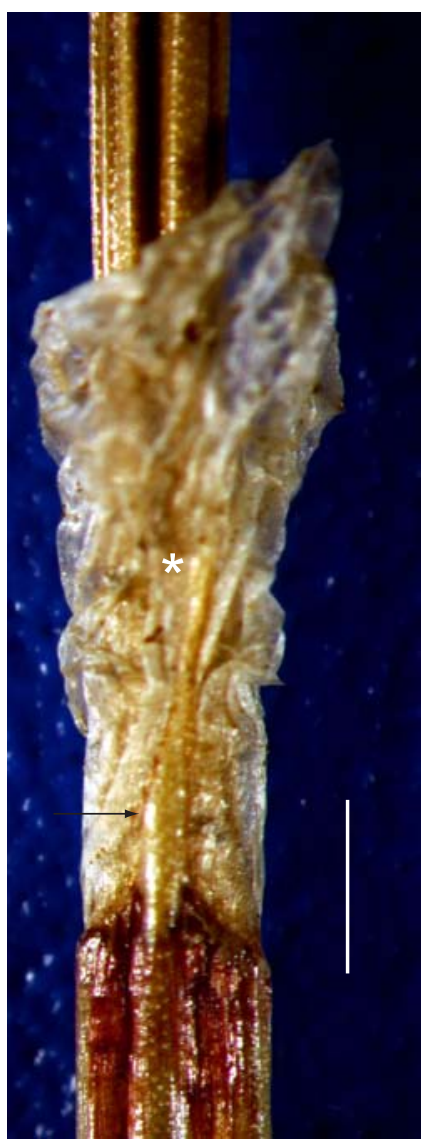

Figura 29. Eleocharis maculosa (Vahl) Roem. \& Schult. (B. Lutz 1570). Ápice da bainha com seta indicando o mucron (*apêndice hialino) (barra $=1 \mathrm{~mm}$ ).

Figure 29. Eleocharis maculosa (Vahl) Roem. \& Schult. (B. Lutz 1570). Sheath apex with an arrow indicating mucro (*hyaline appendage) (scale bar $=1 \mathrm{~mm})$. 


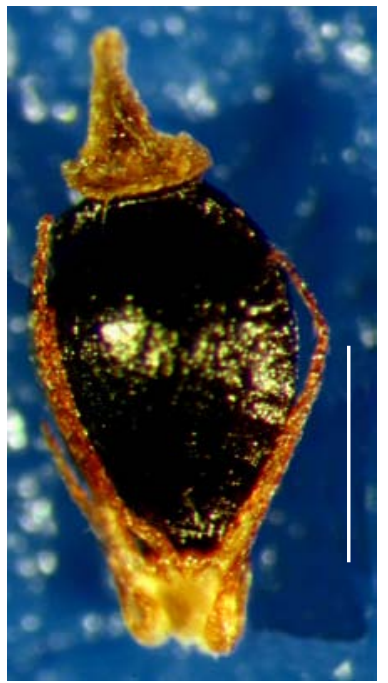

Figura 30. Eleocharis maculosa (Vahl) Roem. \& Schult. (B. Lutz 1570) Aquênio (barra $=0,5 \mathrm{~mm}$ ).

Figure 30. Eleocharis maculosa (Vahl) Roem. \& Schult. (B. Lutz 1570). Achene (scale bar $=0.5 \mathrm{~mm})$.

na base, anteras sem apículo ou inconspicuamente apiculadas, amarelas, por vezes com máculas castanhas. Estigma 2-fido. Aquênios negros a castanho-escuros, obovóides, raro suborbiculares, 1-1,2 X 0,5-0,7 mm, lenticulares, superfície inconspicuamente reticulada, lustrosa, 2-costados, estipitados, ápice com um colo; estilopódio creme-pálido a castanho, cônico lateralmente comprimido, menor ou igual que $0,5 \mathrm{~mm}$ de comprimento.

Nome vulgar: junco.

Distribuição geográfica: AMÉRICA: Estados Unidos, Bahamas, República Dominicana, Antilhas, Guatemala, Honduras, Nicarágua, Venezuela, Colômbia, Brasil (RR, PB, PE, BA, MS, ES, RJ, SP, PR, SC e RS), Equador, Peru, Bolívia, Chile, Argentina e Uruguai. ÁFRICA: África do Sul

Floração e frutificação: janeiro, fevereiro, março, maio, agosto, outubro, novembro e dezembro.

Habitat: brejos, lagos artificiais e lagoas.

Material examinado: BRASIL: RIO DE JANEIRO: Sapucaia, 21 S 59', 42 W 54', $3^{\circ}$ Distrito, Fazendas Selo Verde, 12-VIII-2000, F. B. Pereira 61-25 (RFA); Teresópolis, 22 S 24', 42 W 57', Fazenda da Boa Fé, 11-I-1943, H. Velloso 180 (R); Idem, Soberbo, 11-XI-1929, A. C. Brade 9964 (R); Idem, Granja Comari, 11-II-1964, H. E. Strang 571 (GUA); Idem, Parque Nacional da Serra dos Órgãos, III-1953, J. Vidal II-6615(953) (R); Idem, ibidem, V-1953, J. Vidal II-6674(953) (R); Idem, Serra dos Órgãos, Barrozo, próximo a Serra dos Cavalos, 19-XI-1912, J. Vidal II-5346(952) (R); Petrópolis, 22 S 30', 43 W 10', Quitandinha, XI-1939, B. Lutz 1533 (R); Idem, ibidem, 18-I1940, B. Lutz 1554a (R); Idem, ibidem, 18-I-1940, B. Lutz 1570 (R); Idem, Correias, Vale do Bonfim, Estrada do Bonfim, 3501, km 3,5, 18-XII-2001, C. P. Bove et al. 927 (R); Silva Jardim, 22 S 39', 42 W 23', Estrada para Gaviões, ca. 12 km de Silva Jardim, 19-II-2003, C. P. Bove \& W. Costa 1105 (R); Duque de Caxias, 22 S 47', 43 W 18', Serra da Estrela, 16-II-1917, J. César Diogo 642 (R); Maricá, 22 S 55', 42 W 49', Restinga de Maricá, 3-II-1999, C. P. Bove et al. 420 (R); Idem, Itaipuaçu, 22-X-2000, C. P. Bove et al. 751 (R); Idem, 1-I-1990, A. Souza 2874 (R); Rio de Janeiro, 22 S 54', 43 W 12', Alto da Boa Vista, 8-X-1966, D. Sucre 1123 (RB); s/localidade, 28XII-1962, E. Fromm 1253 \& E. Santos 1275 (R-200986).

Comentários: Eleocharis maculosa caracteriza-se pelas espigas, a maioria das vezes, castanho-avermelhadas a castanho-escuras com glumas inferiores sempre verdes na larga carena, 3-nervadas e com grandes margens hialinas e escariosas, de ápice, muitas vezes, emarginado, aquênios negros e, principalmente, pelo apêndice hialino proeminente e mucron no ápice da bainha. Nota-se, muitas vezes, que as espigas vão clareando com o amadurecimento. Espigas ocráceas foram observadas apenas quando encontravam-se com frutos.

Quando E. maculosa apresenta-se com as espigas ocráceas, pode ser facilmente confundida com E. sellowiana. Apesar de serem muito semelhantes, se distinguem por outros caracteres, como os citados na chave de identificação deste trabalho. Algumas vezes, E. maculosa apresenta de uma a duas pequenas glumas estéreis encobertas pelas inferiores.

O material examinado da restinga de Maricá (C.P. Bove et al. 420), descrito e ilustrado por Gil \& Bove (2004), foi erroneamente identificado como E. sellowiana. Este espécime corresponde à E. maculosa, pelo fato de apresentar colmos pontuados, cerdas perigoniais castanhas e aquênios negros com superfície inconspicuamente reticulada. Porém o material adicional examinado, citado na referida bibliografia, está corretamente identificado. Desta forma, a nova ocorrência de E. sellowiana para o estado do Rio de Janeiro procede.

\section{Eleocharis minarum Boeck., Beitr. Cyper. 2: 12. 1890. (Figuras 31-33).}

Ervas eretas, cespitosas, rizomatosas. Colmos $25,5-53 \mathrm{~cm} \mathrm{x}$ 0,4-0,7 $\mathrm{mm}$ na base, quadrangulares, capilares, estriados longitudinalmente, sulcados, verdes a pardos, raro com pontuações castanhoavermelhadas. Bainhas subcoriáceas a membranáceas, castanho-avermelhadas a purpúreas na metade inferior, pardas a esverdeadas com pontuações castanho-avermelhadas em direção ao ápice castanho, 4-5,5 cm de comprimento, sem apêndice hialino no ápice; ápice levemente oblíquo a truncado, com inconspícuo mucron, íntegro. Espigas paucifloras, proliferação ausente, ovóides, raro elipsóides, 3,5-5 $\times 1-2,5 \mathrm{~mm}$, agudas a subagudas, castanho-avermelhadas com máculas pardo-pálidas. Glumas espiraladas, raro subdísticas, carenadas, subcartilaginosas na região central, membranáceas em direção as margens, persistentes, castanho-avermelhadas com carena parda a pardo-pálida, ovaladas a elípticas, ápice agudo, margens castanho-avermelhadas, íntegras, apenas a nervura longitudinal central proeminente, 1,5-2 x 1-1,4 mm. Uma gluma inferior englobando toda a base da espiga, contínua com o colmo, estéril, persistente, carena verde a parda, lados castanhos ou pontuados de castanho, 1-4 mm de comprimento e 0,8-1,2 mm de diâmetro, 3-nervada, nervuras proeminentes, margem hialina e íntegra, ápice subagudo a obtuso. Cerdas perigoniais 3-5, por vezes vestigiais, castanhas, $0,5 \mathrm{~mm}$ de comprimento. Estames 3, filetes hialino-amarelados a castanho-claros, anteras sem apículo, amarelas. Estigma 3-fido. Aquênios amarelados, globosos, 0,7-0,8 mm de diâmetro, sub-rotundos, por vezes, trígonos, superfície estriada longitudinalmente e lustrosa, 3-costados, estípite ausente, colo e espessamento ausentes; estilopódio contínuo com o ápice do aquênio, castanho a castanho-esbranquiçado, piramidal, menor que $0,6 \mathrm{~mm}$ de comprimento.

Nome vulgar: junco.

Distribuição geográfica: AMÉRICA: Brasil (MG, RJ* e SC) e Paraguai. * Nova ocorrência.

Floração e frutificação: novembro.

Habitat: brejos, por vezes, sombreados.

Material examinado: BRASIL: RIO DE JANEIRO: Teresópolis, 22 S 24', 42 W 57', Pedra Chapadão, 8-XI-1929, A. C. Brade 9951 (R).

Comentários: Eleocharis minarum mostrou-se extremamente rara para o estado do Rio de Janeiro, pois fora encontrado um único exemplar coletado no início do século passado. Esta espécie, em herbário, é muito semelhante a E. squamigera, porém após uma análise 
mais minuciosa se distingue pelas diferenças entre seus aquênios, bainhas e colmos.

\section{Eleocharis minima Kunth, Enum. Pl. 2: 139. 1837. (Figuras 34-36)}

Ervas eretas a escandentes, cespitosas, rizomas e estolões ausentes. Colmos 2-16 cm x 0,1-0,5 mm na base, quadrangulares, às vezes de forma inconspícua, capilares, lisos, sulcos ausentes, verdes com pequenas pontuações castanho-avermelhadas, às vezes sem pontuações. Bainhas membranáceas, base purpúrea, por vezes pardas pontuadas de castanho, clareando em direção ao ápice pardoesverdeado, 0,5-2,5 cm de comprimento, sem apêndice hialino no ápice; ápice oblíquo alongado, obtuso, escarioso, com base inteira. Espigas paucifloras, prolíferas, elipsóides, 2-5 × 1-2 mm, agudas,

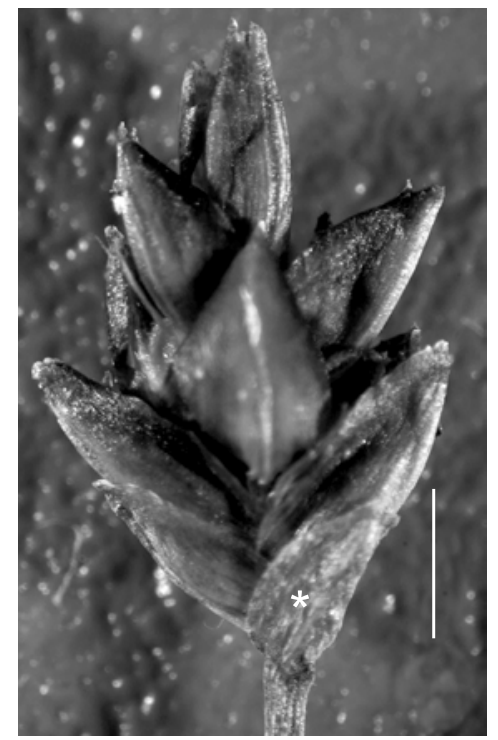

Figura 31. Eleocharis minarum Boeckl. (A. C. Brade 9951). Espiga (*gluma inferior) (barra $=1 \mathrm{~mm})$.

Figure 31. Eleocharis minarum Boeckl. (A. C. Brade 9951). Spike (*lower glume) (scale bar $=1 \mathrm{~mm}$ ).

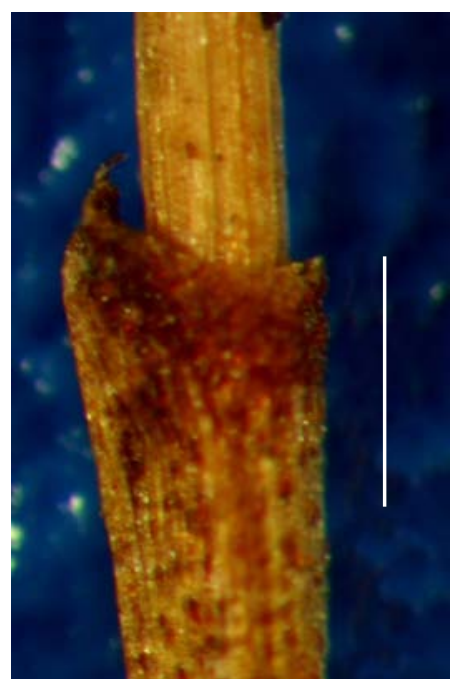

Figura 32. Eleocharis minarum Boeckl. (A. C. Brade 9951). Ápice da bainha $($ barra $=1 \mathrm{~mm})$.

Figure 32. Eleocharis minarum Boeckl. (A. C. Brade 9951). Sheath apex (scale bar $=1 \mathrm{~mm})$. castanhas. Glumas dísticas a subdísticas, carenadas, membranáceas, caducas, carena verde, lados com manchas castanho-avermelhadas, elípticas a lanceoladas, ápice subagudo, margens hialinas, por vezes esbranquiçadas, íntegras, nervuras longitudinais não proeminentes, 1,5-2,5 x 0,7-1,2 mm. Uma gluma inferior englobando toda a base da espiga, contínua com o colmo, quando madura, articulada, estéril, porém com proliferação, persistente, carena verde endurecida, lados, às vezes com máculas castanhas, outras vezes hialinos, 1,3-2,5 mm de comprimento e 0,3-0,5 mm de diâmetro, 3-nervadas, internamente, bem evidentes, margem hialina ampla e íntegra; ápice agudo. Cerdas perigoniais ausentes a 5 , por vezes vestigiais, hialinas esbranquiçadas

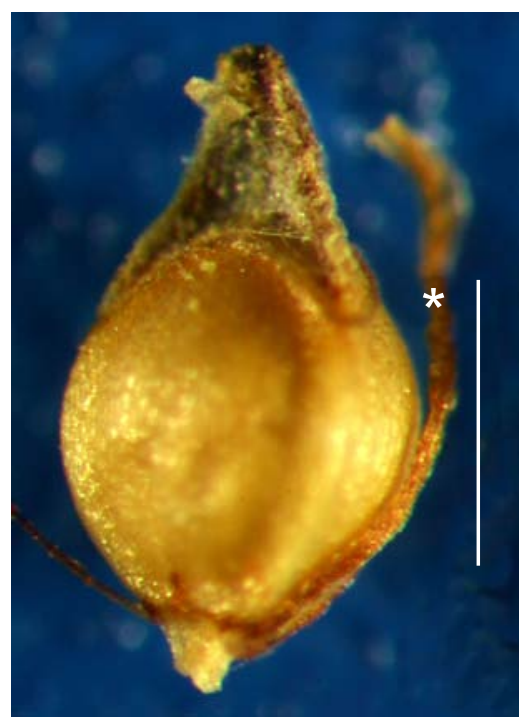

Figura 33. Eleocharis minarum Boeckl. (A. C. Brade 9951). Aquênio (*filete) (barra $=0,5 \mathrm{~mm}$ ).

Figure 33. Eleocharis minarum Boeckl. (A. C. Brade 9951). Achene (*filament) $($ scale bar $=0.5 \mathrm{~mm})$.

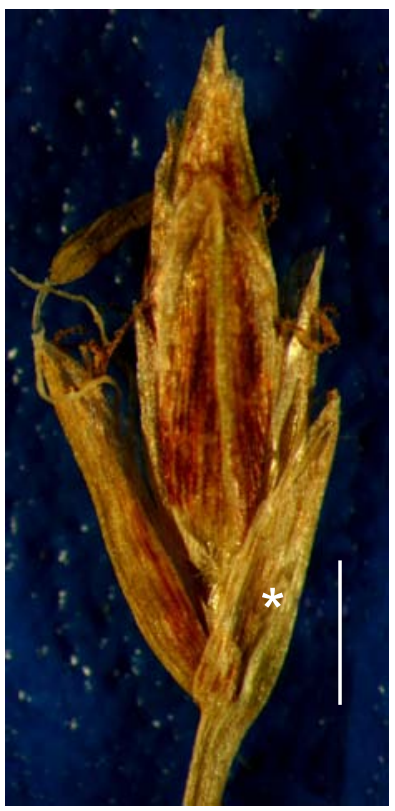

Figura 34. Eleocharis minima Kunth (A. Gil 140). Espiga (*gluma inferior) (barra $=1 \mathrm{~mm})$.

Figure 34. Eleocharis minima Kunth (A. Gil 140). Spike (*lower glume) (scale bar $=1 \mathrm{~mm}$ ). 


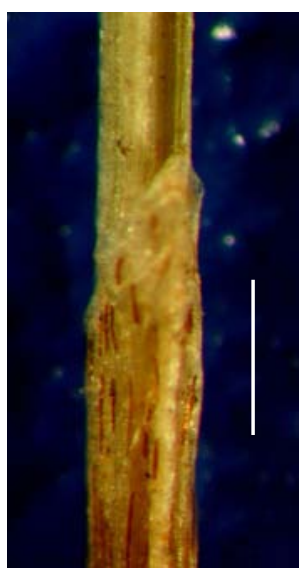

Figura 35. Eleocharis minima Kunth (A. Gil 140). Ápice da bainha (barra $=0,5 \mathrm{~mm}$ )

Figure 35. Eleocharis minima Kunth (A. Gil 140). Sheath apex (scale bar $=0.5 \mathrm{~mm})$

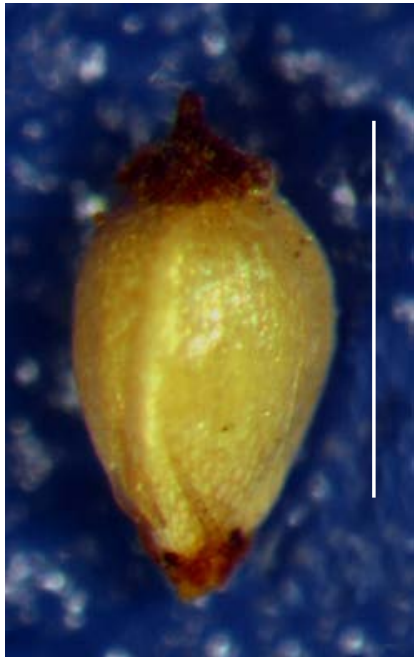

Figura 36. Eleocharis minima Kunth (A. Gil 140). Aquênio (barra = $0,5 \mathrm{~mm})$.

Figure 36. Eleocharis minima Kunth (A. Gil 140). Achene (scale bar $=$ $0.5 \mathrm{~mm})$.

a acastanhadas, 0,4-0,5 $\mathrm{mm}$ de comprimento. Estames 2-3, filetes hialinos, às vezes esbranquiçados, anteras brevemente apiculadas, amarelas. Estigma 3-fido. Aquênios alvos, elipsóides, 0,4-0,6 x 0,3$0,5 \mathrm{~mm}$, trígonos a sub rotundos, superfície com fileiras longitudinais de células arredondadas pouco evidentes, 3-costados, estipitados ou não, ápice com um pequeno colo; estilopódio, castanho, piramidal, menor que $0,1 \mathrm{~mm}$ de comprimento.

Nomes vulgares: lodo e cabelo-de-porco.

Distribuição geográfica: AMÉRICA: Estados Unidos, México, Cuba, Jamaica, Belize, Guatemala, Honduras, El Salvador, Nicarágua, Costa Rica, Antilhas, Panamá, Venezuela, Colômbia, Brasil (RR, PB, PE, BA, MT, MS, MG, ES, RJ, SP, SC e RS), Equador, Bolívia, Paraguai, Argentina e Uruguai.

Floração: o ano inteiro.

Frutificação: janeiro, março, maio, junho, julho, agosto, outubro, novembro e dezembro.

Habitat: córregos e lagoas.
Material examinado: BRASIL: RIO DE JANEIRO: Campos dos Goytacazes, 21 S 45', 41 W 19', Lagoa Feia, Ponta Grossa dos Fidalgos, 12-IX-1953, Segadas-Vianna et al. Restinga I-3 (R); Idem, ibidem, 11-VII-1978, D. Araújo \& N. C. Maciel 2109 (GUA); Idem, ibidem, Pontal, as margens da lagoa, 17-IV-1979, D. Araújo \& N. C. Maciel 3003 (GUA); Idem, ibidem, 6-VI-1979, D. Araújo \& N. C. Maciel 3122 (GUA); Idem, ibidem, ao lado do canal Ururaí, em ilha artificial recentemente formada pela draga, 9-X-1979, D. Araújo 3263 (GUA); Idem, ibidem, Canto do Toco, 11-VI-1980, D. Araújo \& N. C. Maciel 3825 (GUA); Macaé, 22 S 22', 41 W 47', na orla da Lagoa Comprida, 1-VI-1981, D. Araújo \& N. C. Maciel 4469 (GUA); Idem, entre Lagoa Comprida e Carapebus, brejo de Laplace, 27-VIII-1982, D. Araújo \& N. C. Maciel 5237 (GUA); Teresópolis, 22 S 24', 42 W 57', ASBAC, 4-III-2003, A. Gil 140 (R); Arraial do Cabo, 22 S 47', 43 W 18', rua 12, 1-V-1972, C. Ramalho \& A. B. Campelo s/n (RBR-4718); Idem, ibidem, 1-V-1972, C. Ramalho \& A. B. Campelo s/n (RBR-4720); Idem, 22 S 52', 42 W 01', entre Lagoa de Araruama e Praia de Massambaba, brejo dos Espinhos, 20-XII-1982, D. S. Pedrosa et al. 754 (GUA); Idem, 22 S 57', 42 W 01', Praia do Pontal, 11-VII-1953, Segadas-Vianna et al. Restinga I-45 (R); Maricá, 22 S 55', 42 W 49', Restinga da Barra, atrás da primeira duna, próximo a depressão úmida, 8-VIII-1984, D. Araújo \& L. D. Lacerda 6345 (GUA); Idem, Área de Proteção Ambiental, em depressão, dentro da restinga de Ericáceas, 1-III-1990, D. Araújo \& M. C. A. Pereira 9115 (GUA).

Comentários: Esta espécie apresenta características bastante peculiares: ausência de rizomas e estolões, porém, muitas vezes, apresenta espigas prolíferas, que é outra forma de produzir clones, ou seja, com função semelhante a rizomas e estolões. Os colmos são extremamente finos, principalmente, quando submersos. Outra característica marcante é a disposição das glumas: dística a subdística. E. minima, sem espigas prolíferas pode ser confundida com E. nana pelo seu hábito similar, porém são distintas pela espiga elíptica, castanha e aguda, com glumas dísticas a subdísticas em E. minima e espigas ovaladas, esverdeadas a pardo-claras e subagudas, com glumas espiraladas em E. nana.

12. Eleocharis montana (Kunth) Roem. \& Schult., Syst. Veg. 2:153. 1817. (Figuras 37-39)

\section{Scirpus montanus Kunth, Nov. Gen. Sp. 1:226. 1816.}

Ervas eretas, cespitosas, rizomatosas. Colmos 20- $117 \mathrm{~cm} \mathrm{x}$ 1-3,5 mm na base, cilíndricos, regularmente septados, nodulosos, septos transversais evidentes, lisos, quando secos estriados longitudinalmente, sulcos ausentes, verdes. Bainhas subcoriáceas, às vezes membranáceas, castanho-avermelhadas a purpúreas na base, pardoesverdeadas acima, castanhas no ápice, $4-14 \mathrm{~cm}$ de comprimento, sem apêndice hialino no ápice; ápice truncado, por vezes oblíquo, mucronado, mucron bastante proeminente, íntegro. Espigas multifloras, proliferação ausente, oblongo-lanceoladas a oval-lanceoladas quando maduras e obovóides a oblongas quando imaturas, 0,6-2,5 cm x 2-4 mm, agudas a obtusas, ocres a castanhas. Glumas espiraladas, carenadas, membranáceas, caducas, pardas a esverdeadas na carena, lados com manchas avermelhadas a castanhas, elípticas a oval-lanceoladas, ápice subagudo a obtuso, margens hialinas e íntegras, apenas a nervura longitudinal central proeminente, $2-3,5 \times 0,5-1,2 \mathrm{~mm}$. Duas glumas inferiores, a mais externa englobando toda a base da espiga, contínua com o colmo, 1,5-3 de comprimento e 1,2-2 de diâmetro, a mais interna oposta a externa, articulada com o colmo, 1,5-2,5 $\mathrm{x}$ 1,5-2 mm, estéreis, persistentes, carenas verdes, lados castanhos a pálido-esverdeados, arredondadas, margens hialinas com pequenas máculas castanhas, íntegras, ápice obtuso, as vezes subagudo. Cerdas 


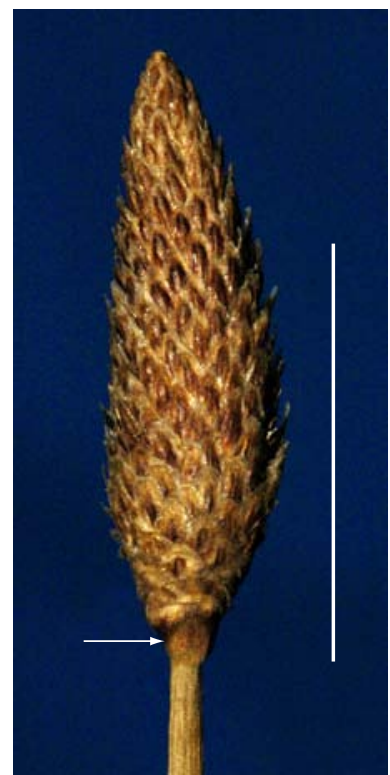

Figura 37. Eleocharis montana (Kunth) Roem. \& Schult. (A. Gil et al. 26). Espiga com seta indicando gluma inferior externa (barra $=10 \mathrm{~mm}$ ).

Figure 37. Eleocharis montana (Kunth) Roem. \& Schult. (A. Gil et al. 26). Spike with an arrow indicating external lower glume $($ bar $=10 \mathrm{~mm})$.



Figura 38. Eleocharis montana (Kunth) Roem. \& Schult. (A. Gil et al 26). Ápice da bainha com seta indicando o mucron (barra $=1 \mathrm{~mm})$.

Figure 38. Eleocharis montana (Kunth) Roem. \& Schult. (A. Gil et al. 26). Sheath apex with an arrow indicating mucro (scale bar $=1 \mathrm{~mm}$ ).

perigoniais 4-5(6), castanho-claras a pardo-hialinas, 0,7-2 $\mathrm{mm}$ de comprimento. Estames 1-2, filetes castanho-claros na base, tornando-se hialinos em direção as anteras, anteras apiculadas, amarelas com máculas castanhas. Estigma 2(3)-fido, podendo a mesma espiga apresentar ambos. Aquênios oliváceos, castanho-pálidos, ou ainda, castanho-esverdeados, obovóides, 0,7-1 x 0,5-1 mm, lenticulares, raro inconspicuamente trígono, superfície com fileiras longitudinais de células retangulares dispostas verticalmente e pontuada, lustrosa, 2-costados, estipitados, com um atenuado colo no ápice; estilopódio

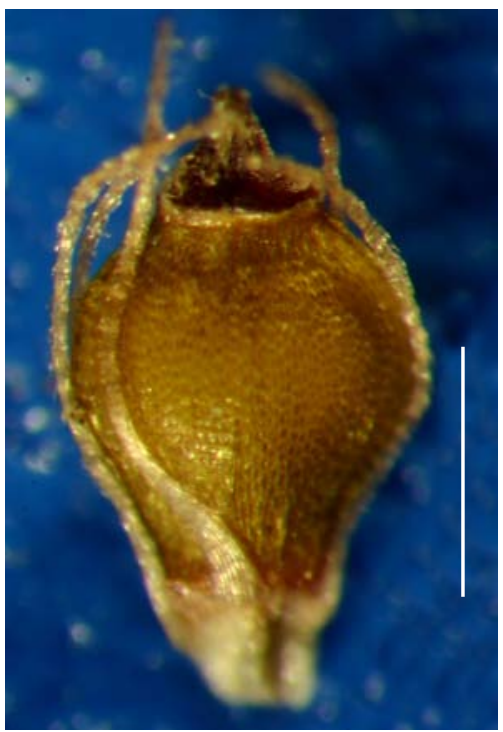

Figura 39. Eleocharis montana (Kunth) Roem. \& Schult. (A. Gil et al. 26). Aquênio (barra $=0,5 \mathrm{~mm}$ ).

Figure 39. Eleocharis montana (Kunth) Roem. \& Schult. (A. Gil et al. 26). Achene (scale bar $=0.5 \mathrm{~mm})$.

pardo a castanho-escuro, cônico lateralmente comprimido ou horizontalmente comprimido, menor que $0,5 \mathrm{~mm}$ de comprimento.

Nome vulgar: junco.

Distribuição geográfica: AMÉRICA: Estados Unidos, México, Cuba, Porto Rico, Haiti, Jamaica, Antilhas, Guatemala, Honduras, El Salvador, Nicarágua, Costa Rica, Panamá, Colômbia, Venezuela, Brasil (RR, AM, PE, MT, BA, MG, RJ, SP, PR, SC e RS), Equador, Peru, Bolívia, Chile, Paraguai, Argentina e Uruguai.

Floração e frutificação: o ano inteiro.

Habitat: açudes, brejos e margem de ilha de rios.

Material examinado: BRASIL: RIO DE JANEIRO: São Fidélis, 21 S 38', 41 W 44', RJ-146, entre Cambiasca e Santa Maria Madalena, margem do Rio Grande, 25-VIII-1981, M. B. Casari et al. 588 (GUA); Três Rios, 22 S 07', 43 W 12', montante do encontro dos três rios, 26-IX-2003, A. Gil et al. 143 (R); São José do Vale do Rio Preto, 22 S 09', 42 W 55', Manancial de Maravilha Reser. da CAEMP, 29IX-1993, G. Sampaio \& I. Fraga s/n (GUA-41425); Vassouras, 22 S 24', 43 W 39', Morro Azul, 27-II-1940, H. Monteiro 2190 (RBR); Resende, 22 S 28', 44 W 26', em áreas das Indústrias Nucleares do Brasil (Nucleobras), na orla da Mata do Rodolfo, Margem do Reservatório do Funil, 11-IX-1990, J. P. P. Carauta et al. 6245 (GUA); Miguel Pereira, 22 S 27', 43 W 28', Pr. Ferros, entre Miguel Pereira e Morro Azul, 25-III-1962, G. F. J. Pabst 6897 (HB); Itatiaia, 22 S 29', 44 W 33', Faz. Aleluia, Rio Campo Belo, 15-VIII-2001, A. Gil et al. 26 (R); Barra do Piraí, Ipiabas, 22 S 22', 43 W 52', Faz. da Floresta, 9-IX-1977, P. P. A. Laclette 855 (R); Petrópolis, 22 S 30', 43 W 10', 10-VII-1967, C. R. Campelo s/n (RBR-4721); Piraí, 22 S 37', 43 W 53', Margem do Reservatório de Santana, 13-X-1986, J. P. P. Carauta 5371 (GUA); Duque de Caxias, 22 S 47', 43 W 18', Estrada Rio-Petrópolis, Baixada fluminense, 10-VII-1967, C. R. Campelo s/n (RBR-4723); Idem, 12-VII-1973, C. R. Campelo s/n (R201857); Saquarema, 22 S 55', 42 W 30', Estrada paralela à RJ-106 a 5 km de Bacaxá, 7-X-2000, C. P. Bove et al. 741 (R); Maricá, 22 S 55', 42 W 49', Rod. Amaral Peixoto km 17, 19-X-1987, A. A. M. de Barros 151 \& K. Tanizaki 67 (RFA); Idem, Inoã, 22 S 55', 42 W 55', Rod. Amaral Peixoto km 17, 23-V-1988, A. A. M. de Barros 325 \& K. Tanizaki 170 (RFA); Rio de Janeiro, 22 S 54', 43 W 12', 
Jacarepaguá, Recreio dos Bandeirantes, 9-I-1949, Palácios-Balegjno \& Cuezzo 4036 (R).

Comentários: Esta espécie é facilmente identificada por apresentar o ápice da bainha mucronado sem apêndice hialino; juntamente com espigas oblongo-lanceoladas a oval-lanceoladas quando maduras e obovóides a oblongas quando imaturas, ocráceas a castanhas.

Eleocharis montana apresenta grande polimorfismo em relação aos seus aquênios, porém mantém algumas características constantes, como: pontuações na superfície, 2-costas e com estípite e estilopódio da mesma cor (diferente da cor do aquênio).

\section{Eleocharis mutata (L.) Roem. \& Schult., Syst. Veg.} 2:155. 1817. (Figuras 40-42)

\section{Scirpus mutatus L., Syst. Nat. 10: 867. 1759.}

Ervas eretas, cespitosas, estoloníferas. Colmos 26-102 cm x 2,5-5 mm na base, triangulares de faces côncavas, ângulos não alados, inflado na metade basal, esponjosos, lisos, sulcos ausentes, verdes. Bainhas membranáceas, amareladas a castanho, por vezes purpúreas, 6,5-20 cm de comprimento, sem apêndice hialino no ápice; ápice oblíquo, acuminado, íntegro. Espigas multifloras, proliferação ausente, cilíndricas, 1,5-4 cm x 3,5-6 mm, subagudas a obtusas, ocres. Glumas espiraladas, carenadas, subcartilaginosas na região central e membranáceas em direção às margens, persistentes, região da carena endurecida e esverdeada, lados castanho-claros a esverdeados, castanho-pontuadas internamente, oblongas a sub-orbiculares, ápice obtuso, margens hialinas, escariosas no ápice, nervuras longitudinais proeminentes, principalmente a central, 3-4 × 3-4 mm. Uma gluma inferior englobando a base da espiga, contínua com o colmo, estéril, persistente, pardo-esverdeada, margem hialina e escariosa com pequenas manchas castanhas formando uma linha, 2-3

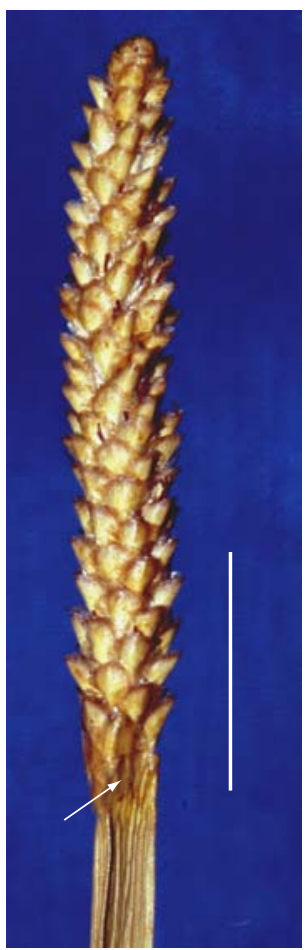

Figura 40. Eleocharis mutata (L.) Roem. \& Schult. (A. Gil et al. 52). Espiga com seta indicando a gluma inferior (barra $=10 \mathrm{~mm}$ ).

Figure 40. Eleocharis mutata (L.) Roem. \& Schult. (A. Gil et al. 52). Spike with an arrow indicating lower glume (scale bar $=10 \mathrm{~mm}$ ). mm de comprimento e 2-2,5 mm de diâmetro, ápice obtuso. Cerdas perigoniais (6)7, pardas a castanhas, 2-2,5 $\mathrm{mm}$ de comprimento. Estames 3, filetes hialinos, anteras apiculadas, acastanhadas. Estigma 3-fido. Aquênios castanho-amarelados a pálidos, obovóides, 1,5-2 X 1-1,5 mm, lenticulares, superfície com fileiras de células retangulares, onde as bordas das células formam pequenas costas longitudinais pouco pronunciadas, estípite ausente, ápice com espessamento; estilopódio amarelo a castanho-escuro, deprimido, 0,5-1 $\mathrm{mm}$ de comprimento.

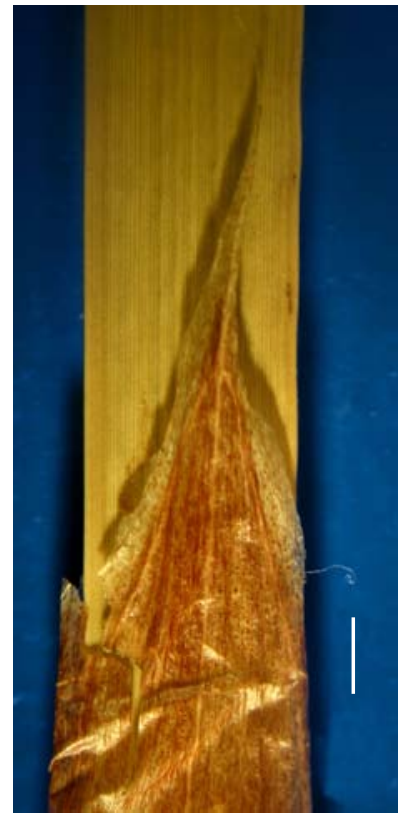

Figura 41. Eleocharis mutata (L.) Roem. \& Schult. (A. Gil et al. 52). Ápice da bainha (barra $=1 \mathrm{~mm})$.

Figure 41. Eleocharis mutata (L.) Roem. \& Schult. (A. Gil et al. 52). Sheath apex (scale bar $=1 \mathrm{~mm})$.

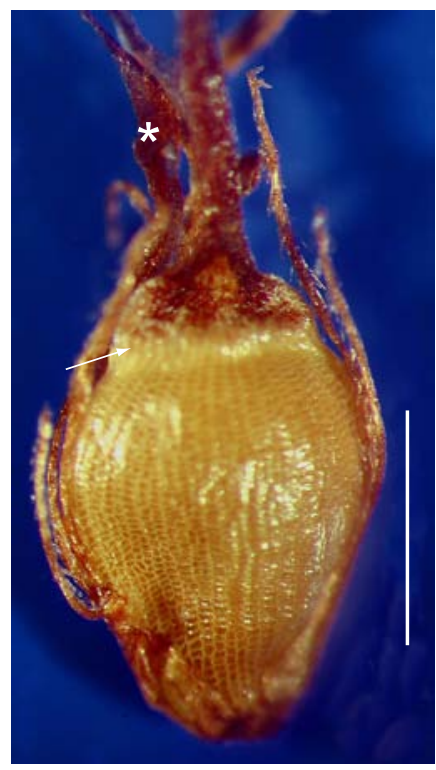

Figura 42. Eleocharis mutata (L.) Roem. \& Schult. (A. Gil et al. 52). Aquênio com seta indicando o espessamento no ápice $(*$ filete $)($ barra $=1 \mathrm{~mm})$.

Figure 42. Eleocharis mutata (L.) Roem. \& Schult. (A. Gil et al. 52). Achene with an arrow indicating thickened apex (*filament) (scale bar $=1 \mathrm{~mm})$. 

nha.

Nomes vulgares: junco, junco-três-quinas, taboinha e ceboli-

Distribuição geográfica: AMÉRICA: Estados Unidos, Bermudas, México, Bahamas, Cuba, Porto Rico, Jamaica, Antilhas, Belize, Guatemala, Honduras, Nicarágua, Costa Rica, Trinidad, Panamá, Venezuela, Colômbia, Guiana, Guiana Francesa, Brasil (MA, PI, CE, PB, PE, BA, SE, MT, GO, MS, MG, ES, RJ, SP, PR, SC e RS), Ilhas Galápagos, Equador, Peru, Bolívia, Paraguai, Argentina e Uruguai. ÁFRICA: Nigéria, Serra Leoa e Libéria. OCEANIA: Austrália.

Floração e frutificação: o ano inteiro.

Habitat: alagados, alagados adjacentes a rios, brejos próximos a lagoas, canais que ligam lagoas e lagoas.

Material examinado: BRASIL: RIO DE JANEIRO: Quissamã, 22 S 06', 41 W 28', a 30 km da Prefeitura, Parque Nacional da Restinga de Jurubatiba, 12-XI-2002, A. Gil et al. 50 (R); Idem, a $27 \mathrm{~km}$ da Prefeitura, Parque Nacional da Restinga de Jurubatiba, Amarra-boi, 13-XI-2002, A. Gil et al. 52 (R); Carapebus, 22 S 11', 41 W 39', Lagoa Paulista, 1-X-1999, C. P. Bove et al. 470 (R); Idem, Parque Nacional da Restinga de Jurubatiba, Lagoa de Cabiúnas, 21-X-2003, C. P. Bove et al. 1256 (R); Macaé, 22 S 22', 41 W 47', Lagoa de Cabiúnas, 5-IV-1983, M. B. Casari \& D. S. D. Araujo 981 (GUA); Idem, Lagoa de Imboacica, na margen, 9-II-1981, D. Araújo \& N. C. Maciel 4216 (GUA); Rio das Ostras, 22 S 31', 41 W 56', 3I-2000, R. Anjos et al. 14 (R); Idem, no Trevo bem próximo à Praia, 23-XI-2000, C. P. Bove et al. 777 (R); Itaboraí, 22 S 44', 42 W 51', à beira do Rio Guaraí, Fora do manguezal, 29-X-1976, D. Araújo 1325 (GUA); Búzios, 22 S 44', 41 W 52', Lagoas de Búzios, ponto de coleta LA1, 5-XII-1984, C. A. Fonteles s/n (GUA-27795); Cabo Frio, 22 S 52', 42 W 01', 1- V-1964, A. Leão \& H. Sick B795 (HB); Idem, Fazenda Campos Novos, próximo á Ilha do Jacaré, 27-III-1979, D. Araújo \& J. P. P. Carauta 2273 (GUA); Maricá, 22 S 55', 42 W 49', Itaipuaçu, Canal do Costa, 6-VII-2003, A. Gil 142 (R); Idem, cerca de $2 \mathrm{~km}$ da entrada da APA de Maricá, 10-II-2000, B. M. B. Leite et al. 05 (R); Idem, Ibdem, 3-XI-2002, A. Gil \& B. Figueira 31 (R); Duque de Caxias, 22 S 47', 43 W 18', Estrada Rio-Petrópolis, Baixada fluminense, 25-III-1970, C. R. Campelo s/n (RBR-4725); Rio de Janeiro, 22 S 54', 43 W 12', Estrada Rio-Petrópolis km 26, s/data, B. Lutz 1587 (R); Idem, Fazenda Modelo, II-1974, C. R. Campelo s/n (R-201859); Idem, Lagoa Rodrigo de Freitas, VIII-1913, s/coletor s/n (R-23473); Idem, Jacarepaguá, Rio das Pedras, Estrada Engenheiro Souza Filho entre os n ${ }^{\text {os }} 21$ e 65, 14-VII-1981, M. B. Casari et al. 576 (GUA); Idem, Baixada de Jacarepaguá, Parque Ecológico, 6-V-1976, D. Araújo 1084 (GUA); Idem, ibidem, Parque Ecológico, caminho que sai a direita, 5-VIII-1977, M. C. Vianna 1102 \& J. P. P. Carauta 2488 (GUA); Idem, Lagoa de Marapendi, 18-II-1951, A. C. Brade \& A. P. Duarte 20577 (RB); Idem, à beira da Lagoa de Marapendí, Reserva Biológica, 11-II-1976, D. Araújo 988 (GUA); Idem, Restinga de Marapendí, 17-III-1963, G. Pabst 7346-A (HB); Idem, Recreio dos Bandeirantes, Praia de Sernambetiba, 4-IV-1952, L. B. Smith 6375 (R); Idem, Ilha da Marambaia, Praia Grande, 16-I-1986, C. M. Rizzini 308 (RFA); Angra dos Reis, Ilha Grande, 23 S 08', 44 W 10', Reserva Biológica Estadual da Praia do Sul, 14-II-1984, D. Araújo 6066 (GUA).

Comentários: Eleocharis mutata caracteriza-se, principalmente, por apresentar colmos triangulares de faces côncavas, gluma inferior estéril e aquênio com espessamento no ápice, características estas que a distingue de $E$. acutangula (vide comentários em $E$. acutangula - loc. cit.). Assim como E. geniculata é muito comum em locais com grande salinidade, e ainda encontra-se, muitas vezes, no estado do Rio de Janeiro, em comunidade com esta espécie. Muitos exemplares em herbário mostraram-se com sinais de herbivoria e preferência a solos humoso-arenosos.
14. Eleocharis nana Kunth, Enum. Pl. 2: 140.1837. (Figuras 43-45)

Ervas eretas, cespitosas, estoloníferas. Colmos $3-13,5 \mathrm{~cm} x$ $0,2-0,5 \mathrm{~mm}$ na base, quadrangulares, capilares, lisos, quando secos

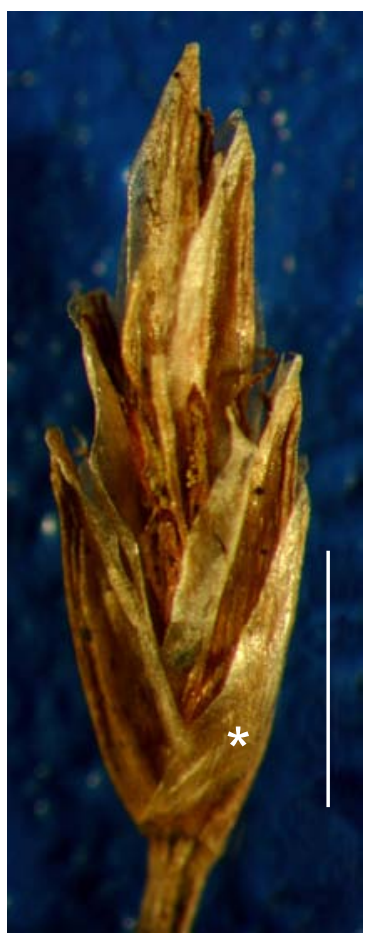

Figura 43. Eleocharis nana Kunth (Z. L. da Silva 18). Espiga (*gluma inferior) (barra $=1 \mathrm{~mm}$ ).

Figure 43. Eleocharis nana Kunth (Z. L. da Silva 18). Spike (*lower glume) (scale bar $=1 \mathrm{~mm})$.

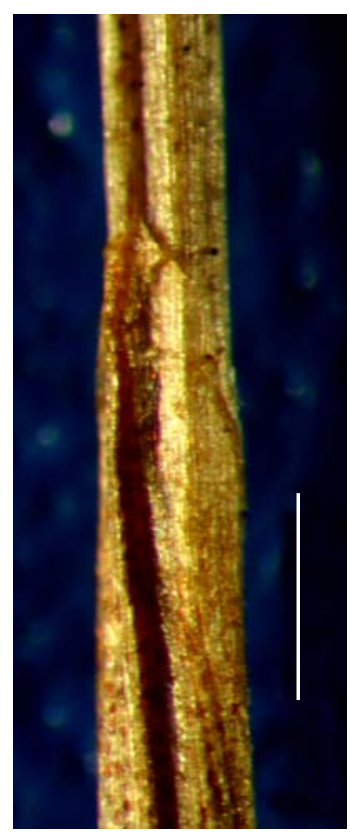

Figura 44. Eleocharis nana Kunth (Z. L. da Silva 18). Ápice da bainha (barra $=0,5 \mathrm{~mm}$ ).

Figure 44. Eleocharis nana Kunth (Z. L. da Silva 18). Sheath apex (scale bar $=0.5 \mathrm{~mm}$ ). 


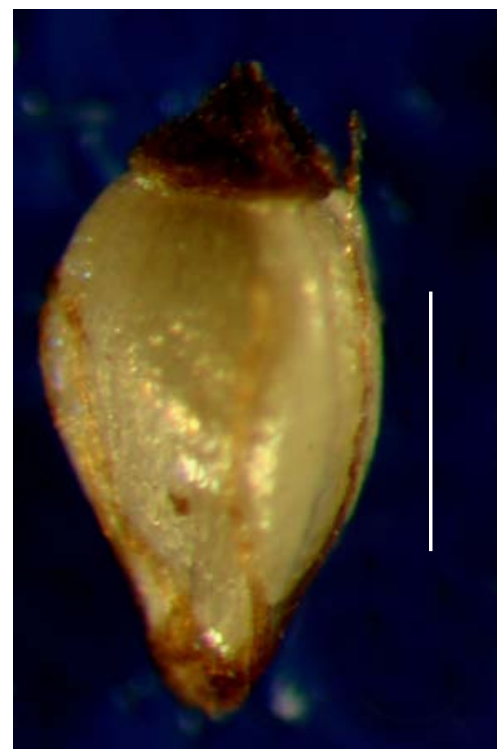

Figura 45. Eleocharis nana Kunth (Z. L. da Silva 18). Aquênio (barra = $0,5 \mathrm{~mm})$.

Figure 45. Eleocharis nana Kunth (Z. L. da Silva 18). Achene (scale bar = $0.5 \mathrm{~mm})$.

sulcados, verdes, intensamente a ligeiramente pontuados de castanho. Bainhas membranáceas, pardo-pálidas, muitas vezes castanho-pontuadas, 1-2,3 cm de comprimento, sem apêndice hialino no ápice; ápice oblíquo, acuminado a obtuso, com pequena fenda na base, escarioso. Espigas paucifloras, proliferação ausente, ovóides a oval-lanceoladas, 2-3,5 x 0,8-1,5 mm, agudas a obtusas, creme-esverdeadas. Glumas espiraladas, carenadas, membranáceas, caducas, região da carena endurecida, verde, lados e margens hialinas, por vezes com manchas castanhas, internamente bem evidentes, ovaladas, ápice obtuso a subagudo, margens hialinas, íntegras, nervuras longitudinais não proeminentes, 1,2-1,6 x 0,6-1 mm. Uma gluma inferior englobando toda a base da espiga, articulada com o colmo, estéril, caduca, carena verde proeminente, lados e margens hialinos largos, 1,5-2 mm de comprimento e 0,2-0,5 mm de diâmetro, 3-nervadas, internamente bem evidentes, margem hialina, escariosa no ápice; ápice obtuso, raro subagudo. Cerdas perigoniais 5, por vezes algumas vestigiais, acastanhadas, 0,3-0,7 $\mathrm{mm}$ de comprimento. Estames 3, filetes hialinos, às vezes esbranquiçados, anteras longamente apiculadas, amarelas. Estigma 3-fido. Aquênios alvo-esverdeados a amarelados, obovóides, 0,7-1 x 0,4-0,5 mm, trígonos, superfície inconspicuamente estriada, 3-costados, brevemente estipitados, ápice com um colo; estilopódio castanho-claro a escuro, piramidal, cerca de $0,2-0,3 \mathrm{~mm}$ de comprimento.

Nome vulgar: junco.

Distribuição geográfica: AMÉRICA: Estados Unidos, México, Cuba, Guiana, Brasil (BA, RJ, SP, PR, SC e RS) e Uruguai.

Floração e frutificação: maio, junho, julho, agosto, setembro e novembro.

Habitat: alagados, interior de restingas em baixios alagáveis e lagoas.

Material examinado: BRASIL: RIO DE JANEIRO: Carapebus, 22 S 11', 41 W 39', Restinga de Carapebus, transecto na área de estudos de Palinologia e Biologia Floral, 12-IX-1995, V. L. C. Martins et al. 200 (R); Idem, ibidem, margem da estrada nova, junto a Faz. São Lázaro, a 2 km em direção a Praia de Carapebus, 20-VIII-1997, I. M. Silva et al. 534 (R); Casimiro de Abreu, Barra de São João, 22 S 35', 41 W 59', 1 km Norte da aldeia da Barra de São João, 3-IX-
1953, Segadas-Vianna et al. Restinga I-7 (R); Arraial do Cabo, $22 \mathrm{~S}$ 57', 42 W 01', Praia do Pontal, 11-VII-1953, Segadas-Vianna et al. Restinga I-46 (R); Rio de Janeiro, 22 S 54', 43 W 12', Restinga de Jacarepaguá, ao lado Norte da Pedra de Itaúna, 23-VI-1969, D. Sucre et al. 5377 (RB); Idem, Recreio dos Bandeirantes, 23-IX-1931, B. Lutz 675 (R); Idem, ibdem, via 11, entre a Lagoa de Marapendí e a Br 6, 19-V-1968, Z. L. da Silva 18 (R).

Comentários: esta espécie apresentou-se semelhante a $E$. mini$m a$. E. nana diferencia-se, principalmente, em relação às espigas (vide comentários E. minima - loc. cit.). Esta espécie apresenta, ainda, uma característica bastante peculiar que é uma pequena fenda na base do ápice da bainha, característica esta não observada nas demais.

\section{Eleocharis pachystyla (C. Wright) C. B. Clarke, Symb. Antill. 2: 72. 1900. (Figuras 46-48)}

\section{Scirpus pachystylus C. Wright, Anal. Acad. Ci. Méd. Habana 82: 79. 1871.}

Ervas eretas, cespitosas, rizomatosas. Colmos $41-91 \mathrm{~cm} x$ 1,2-2,5 mm na base, cilíndricos, regularmente septado, não nodulosos, septos transversais pouco evidentes, estriados longitudinalmente, sulcados, quando secos pardos com cicatrizes castanhas. Bainhas subcoriáceas, às vezes membranáceas no ápice, castanho-avermelhadas a purpúreas até o ápice esverdeado, 7-15,5 cm de comprimento, sem apêndice hialino no ápice; ápice oblíquo, acuminado, íntegro. Espigas multifloras, proliferação ausente, obovóides a ovóides, 4-6x 2,5-4,5 mm, agudas a obtusas, pardo-esverdeadas. Glumas espiraladas, carenadas, membranáceas, caducas, pardo-pálidas na carena, lados acastanhados, oval-lanceoladas a lanceoladas, por vezes oblongas, ápice emarginado a obtuso, margens amplas hialinas e íntegras, apenas a nervura longitudinal central internamente proeminente, 2-3 x 0,8-1,3 mm. Duas glumas inferiores, a mais externa englobando toda ou quase toda a base da espiga, 2,8-3 de comprimento e 1,51,8 de diâmetro, com 7-8 nervuras, internamente, bem evidentes, a mais interna oposta à externa, 2-2,3 x 1-1,2 mm, com 2-5 nervuras, internamente, bem evidentes; articuladas com o colmo, estéreis, caducas, verdes, margens largas hialinas e íntegras, ápice obtuso a emarginado. Cerdas perigoniais 5, pardas a castanho-avermelhadas, 0,6-1,1 mm de comprimento. Estame 3, filetes hialinos a amarelados, anteras sem apículos, amarelas a acastanhadas. Estigma (2)3-fido. Aquênios amarelados a amarelo-escuros, obovóides, 1-1,4 x 0,6$0,8 \mathrm{~mm}$, lenticulares a inconspicuamente trígonos, superfície lisa a inconspicuamente estriada, (2)3-costados, estipitado, com um atenuado colo no ápice; estilopódio castanho, piramidal a cônico comprimido lateralmente, 0,5-0,7 mm de comprimento.

Nome vulgar: junco.

Distribuição geográfica: AMÉRICA: México, Cuba, República Dominicana, Porto Rico, Honduras, Nicarágua, Costa Rica, Antilhas, Panamá, Venezuela, Colômbia, Trinidad, Guiana e Brasil (PE e RJ*). * Nova ocorrência.

Floração e frutificação: agosto.

Habitat: margens de riachos e córregos.

Material examinado: BRASIL: RIO DE JANEIRO: Silva Jardim, 22 S 39', 42 W 23', 15-VIII-1958, E. Pereira 4196 (RB).

Comentários: Eleocharis pachystyla mostrou-se extremamente rara para o estado do Rio de Janeiro, pois fora encontrado um único exemplar coletado em meados do século passado. Tem como características distintivas seu grande estilopódio, espigas, por vezes, obovóides e, algumas vezes, septos dos colmos com cicatrizes onduladas bem evidentes. 


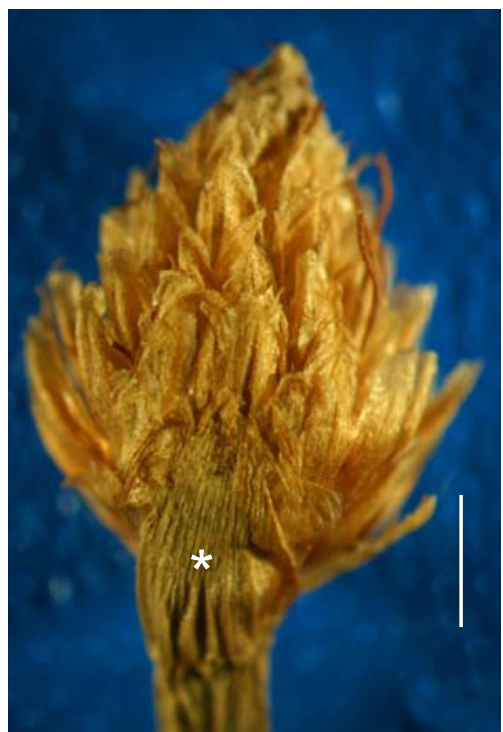

Figura 46. Eleocharis pachystyla (C. Wright) C. B. Clarke (E. Pereira 4196). Espiga (*gluma inferior) (barra $=1 \mathrm{~mm}$ ).

Figure 46. Eleocharis pachystyla (C. Wright) C. B. Clarke (E. Pereira 4196). Spike (*lower glume) (scale bar $=1 \mathrm{~mm})$.

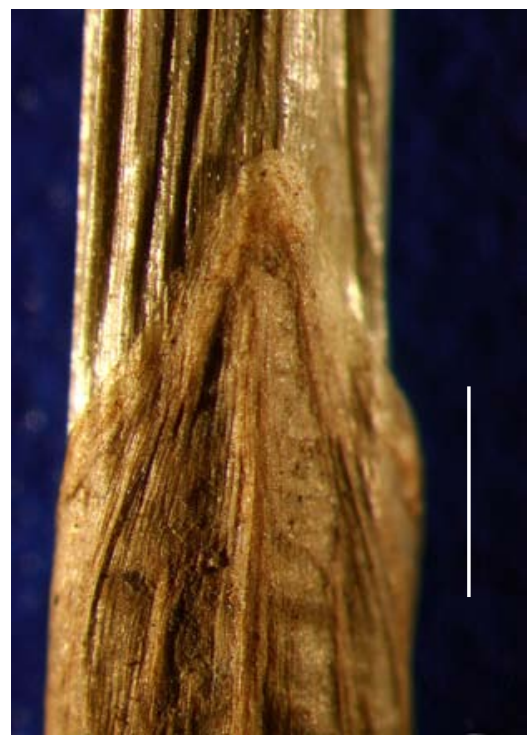

Figura 47. Eleocharis pachystyla (C. Wright) C. B. Clarke (E. Pereira 4196). Ápice da bainha (barra $=1 \mathrm{~mm}$ ).

Figure 47. Eleocharis pachystyla (C. Wright) C. B. Clarke (E. Pereira 4196). Sheath apex (scale bar $=1 \mathrm{~mm}$ ).

\section{Eleocharis radicans (Poir.) Kunth, Enum. Pl. 2: 142.}

1837. (Figuras 49-51)

\section{Scirpus radicans Poir., Encycl. 6: 751. 1805.}

Ervas eretas, cespitosas, estoloníferas. Colmos 5-9,5 cm x 0,2-0,5 mm na base, subcilíndricos a inconspicuamente pentagonais, capilares, estriados longitudinalmente, sulcados, verdes. Bainhas membranáceas, pardas a estramíneas, por vezes castanho-avermelhadas na base, 1,3-2,3 mm de comprimento, sem apêndice hialino no ápice; ápice oblíquo, acuminado, íntegro. Espigas paucifloras, proliferação ausente, lanceoladas a oblongo-lanceoladas, 2,5-3,5 X

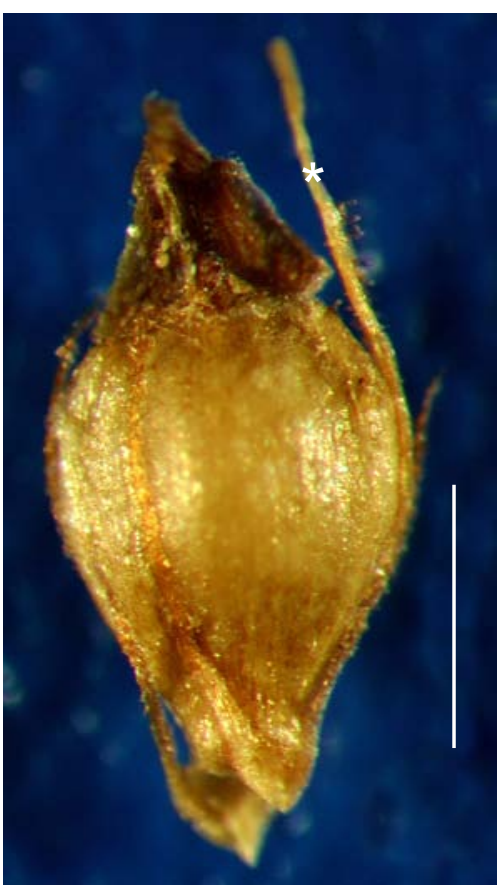

Figura 48. Eleocharis pachystyla (C. Wright) C. B. Clarke (E. Pereira 4196). Aquênio (*filete) (barra $=0,5 \mathrm{~mm}$ ).

Figure 48. Eleocharis pachystyla (C. Wright) C. B. Clarke (E. Pereira 4196). Achene (*filament) (scale bar $=0.5 \mathrm{~mm})$.

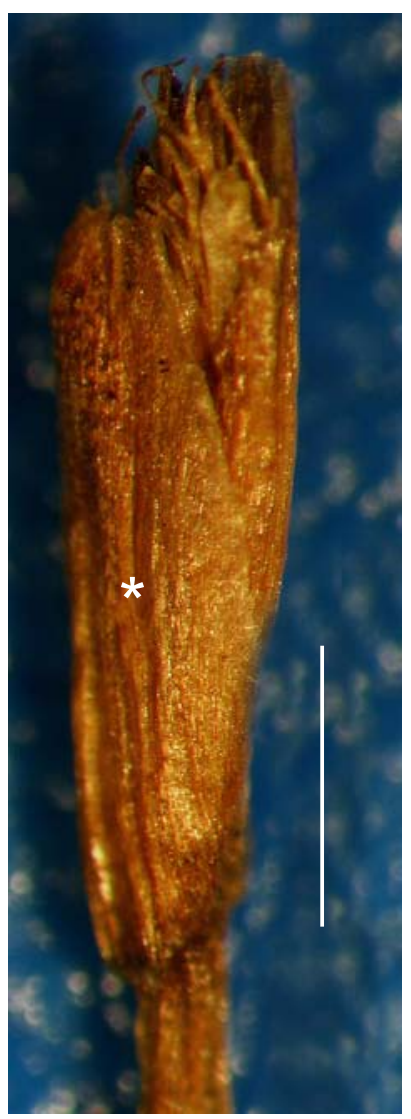

Figura 49. Eleocharis radicans (Poir.) Kunth (Segadas-Vianna et al Serra I -57). Espiga (*gluma inferior) (barra $=1 \mathrm{~mm}$ ).

Figure 49. Eleocharis radicans (Poir.) Kunth (Segadas-Vianna et al Serra I $-57)$. Spike (*lower glume) (scale bar $=1 \mathrm{~mm}$ ). 


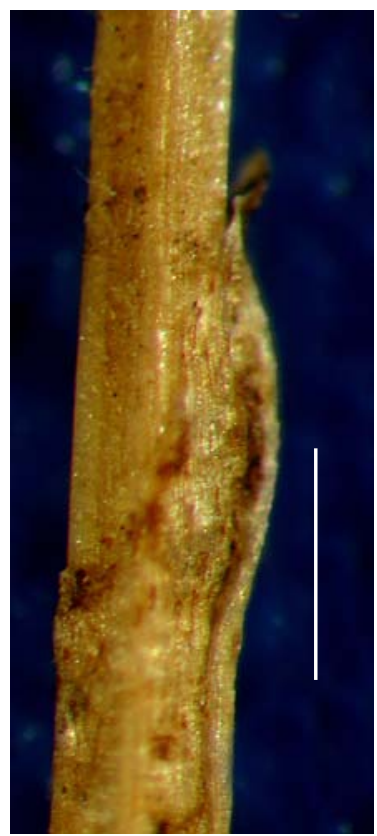

Figura 50. Eleocharis radicans (Poir.) Kunth (Segadas-Vianna et al. Serra I - 57). Ápice da bainha (barra $=0,5 \mathrm{~mm}$ ).

Figure 50. Eleocharis radicans (Poir.) Kunth (Segadas-Vianna et al. Serra I -57). Sheath apex (scale bar $=0.5 \mathrm{~mm})$.

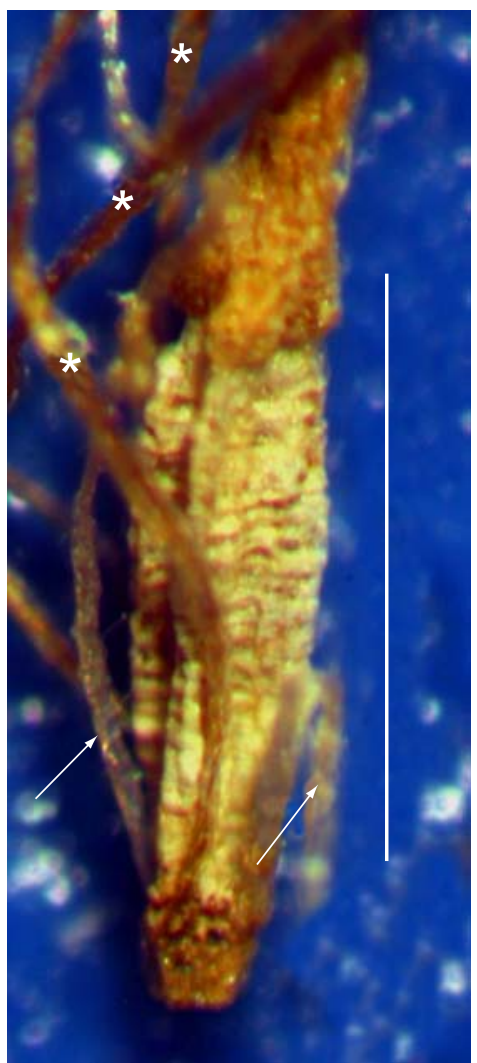

Figura 51. Eleocharis radicans (Poir.) Kunth (Segadas-Vianna et al. Serra I -57). Aquênio imaturo com setas indicando as cerdas perigoniais (*filetes) (barra $=0,5 \mathrm{~mm})$

Figure 51. Eleocharis radicans (Poir.) Kunth (Segadas-Vianna et al. Serra I - 57). Immature achene with arrows indicating bristles (*filaments) (scale bar $=0.5 \mathrm{~mm})$
0,6-0,8 mm, agudas a obtusas, castanho-claras. Glumas espiraladas a subdísticas, carenadas, membranáceas, caducas, castanho-amareladas, lados, às vezes, com manchas castanho-purpúreas, lanceoladas, ápice agudo a subagudo, margens hialinas, íntegras, nervuras longitudinais não proeminentes, 2,2-2,5 x 1-1,3 mm. Uma gluma inferior englobando não só toda a base da espiga, como quase toda a espiga, articulada com o colmo, fértil, caduca, castanho-amareladas, às vezes, castanho-purpúreas, carena larga e endurecida, 2-2,3 mm de comprimento e 0,3-0,5 mm de diâmetro, margem hialina e escariosa; ápice obtuso a subagudo. Cerdas perigoniais 3, alvas a amareladas, 2-2,5 mm de comprimento. Estames 3, filetes estramíneos, anteras longamente apiculadas, amarelas. Estigma 3-fido. Aquênios imaturos, estramíneos a ocráceos, elipsóides, ca. 0,5-0,7 x 0,3-0,4 mm, trígonos, superfície com 4-5 fileiras longitudinais de células retangulares dispostas horizontalmente, inconspicuamente 3-costados, estípites ausentes, ápice com um colo; estilopódio, castanho, piramidal, com $0,2 \mathrm{~mm}$ de comprimento.

Nome vulgar: junco e cabelo de porco.

Distribuição geográfica: AMÉRICA: Estados Unidos, México, Cuba, Haiti, República Dominicana, Porto Rico, Guatemala, Honduras, El Salvador, Nicarágua, Antilhas, Panamá, Brasil (RJ*, SP, SC e RS), Peru, Chile, Argentina e Uruguai. * Nova ocorrência.

Floração e frutificação: fevereiro, julho e dezembro.

Habitat: lagoas.

Material examinado: BRASIL: RIO DE JANEIRO: Resende, 22 S 28', 44 W 26', Serra do Itatiaia, Base das Agulhas Negras, 28II-1953, Segadas-Vianna et al. Serra I - 57 (R).

Comentários: Eleocharis radicans também mostrou-se extremamente rara para o estado do Rio de Janeiro, pois fora encontrado um único exemplar coletado em meados do século passado. Esta espécie caracteriza-se por apresentar sua única gluma inferior além de fértil, com quase o mesmo comprimento da própria inflorescência e sempre 3 cerdas perigoniais longas, com escabras esparsas.

Não foram encontrados aquênios maduros no material examinado.

\section{Eleocharis sellowiana Kunth, Enum. Pl. 2:149. 1837. (Figuras 52-54)}

Ervas eretas, cespitosas, estoloníferas. Colmos 4,5-44 cm x 0,51,8 mm na base, cilíndricos, inconspicuamente esponjosos, estriados longitudinalmente, brevemente sulcados, verdes, não pontuados. Bainhas membranáceas, creme-pálidas na base, avermelhadas ou purpúreas na região mediana, creme-esverdeadas a avermelhadas ou purpúreas, próximo ao ápice, com 5 nervuras longitudinais verdes bem evidentes, 1-5,5 cm de comprimento, apêndice hialino no ápice; ápice oblíquo a truncado, mucronado, íntegro. Espigas multifloras, proliferação ausente, elipsóides, 1-3,5 cm x 2-4 mm, agudas, obtusas, quando imaturas, pardo-esverdeadas na base e castanho-avermelhadas no ápice, às vezes castanho-claras. Glumas espiraladas, carenadas, membranáceas, caducas, região da carena verde-amarelada, geralmente, lados com manchas castanho-avermelhadas a castanhas, na ausência dessas manchas os lados são pardo-pálidos, elípticas a oval-lanceoladas, às vezes, oblongas, ápice obtuso a subagudo, margens hialinas, íntegras, nervuras longitudinais não proeminentes, 2,5-3,5 x 0,8-1,3 mm. Duas glumas inferiores, articuladas com o colmo, estéreis, caducas, verdes na região da larga carena, clareando em direção às margens, 2-2,5 x 0,8-1,2 mm, 3-nervadas, internamente, bem evidentes, margens hialinas e íntegras, ápice obtuso. Cerdas perigoniais 7(8), raro ausentes, alvas a castanho-pálidas, 0,5-1 mm de comprimento. Estames 3, filetes castanho-claros a hialinos, anteras sem apículo, amareladas, por vezes com máculas castanhas. Estigma 2(3)-fido. Aquênios oliváceos a castanho-claros, obovóides, raros sub-orbiculares, 0,8-1 x 0,5-0,8 mm, lenticulares, superfície lisa 


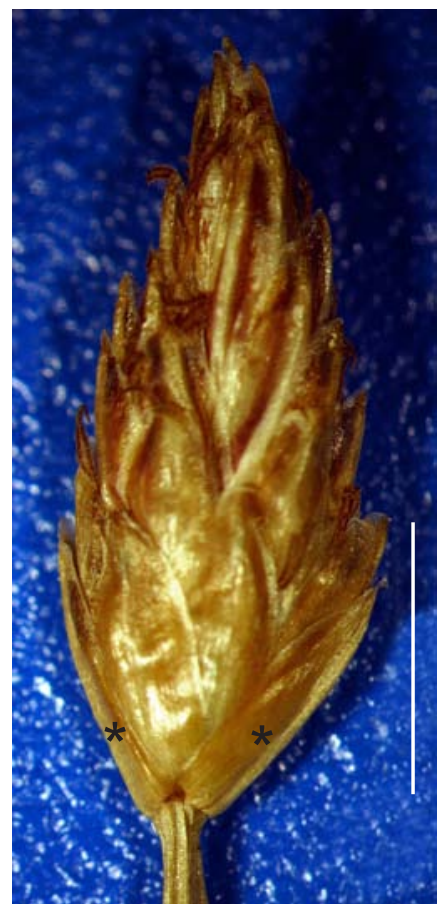

Figura 52. Eleocharis sellowiana Kunth. (R. Fulks s/nº R-138960). Espiga ( $*$ glumas inferiores) (barra $=5 \mathrm{~mm}$ ).

Figure 52. Eleocharis sellowiana Kunth. (R. Fulks s/nº, R-138960). Spike (*lower glumes) (scale bar $=5 \mathrm{~mm}$ ).

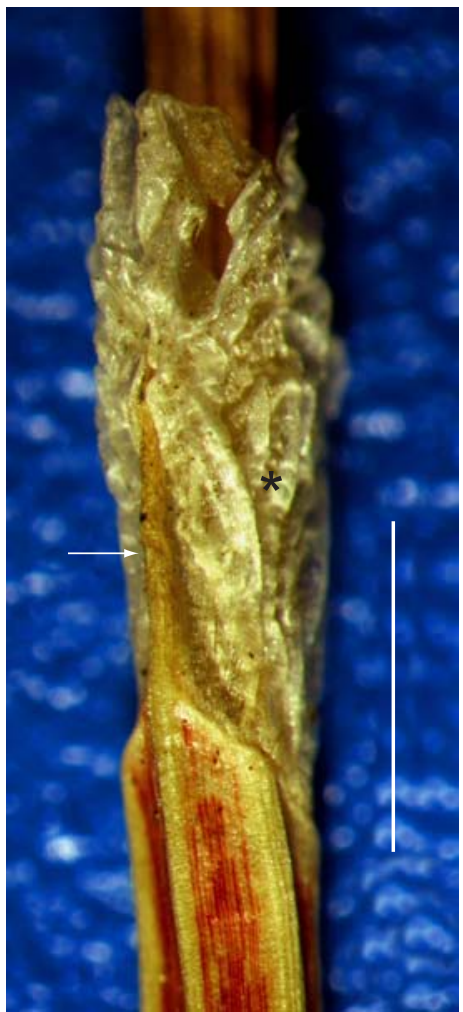

Figura 53. Eleocharis sellowiana Kunth. (R. Fulks s/nº, R-138960). Ápice da bainha com seta indicando o mucron (*apêndice hialino) (barra $=0,5 \mathrm{~mm}$ ).

Figure 53. Eleocharis sellowiana Kunth. (R. Fulks s/nº, R-138960). Sheath apex with an arrow indicating mucro (*hyaline appendage) (scale bar = $0.5 \mathrm{~mm}$ ).

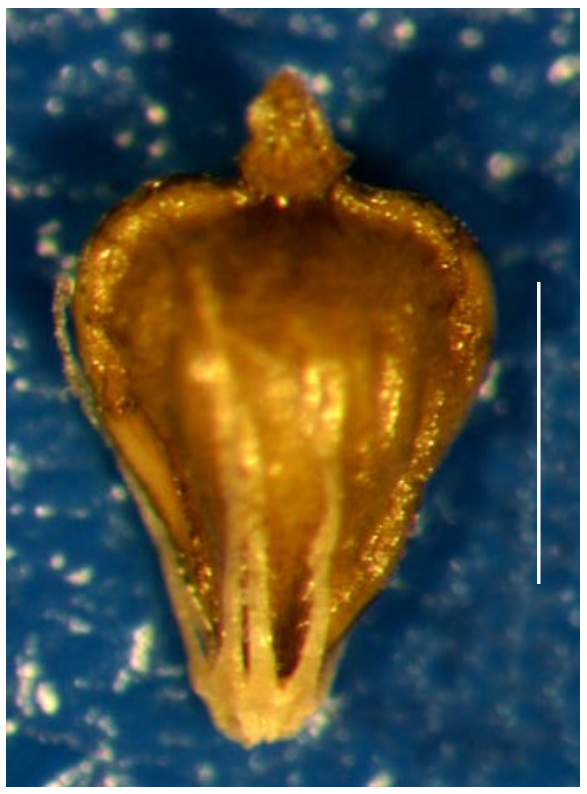

Figura 54. Eleocharis sellowiana Kunth. (R. Fulks s/nº, R-138960). Aquênio (barra $=0,5 \mathrm{~mm})$.

Figure 54. Eleocharis sellowiana Kunth. (R. Fulks s/nº, R-138960). Achene (scale bar $=0.5 \mathrm{~mm})$.

e lustrosa, 2-costados, estipitados, ápice com um colo; estilopódio castanho-claro a pardo-esverdeado, cônico comprimido lateralmente, menor ou igual a $0,5 \mathrm{~mm}$ de comprimento.

Nomes vulgares: junco, junco-manso e junco-fino.

Distribuição geográfica: AMÉRICA: México, Guatemala, Honduras, El Salvador, Nicarágua, Costa Rica, Antilhas, Panamá, Colômbia, Venezuela, Guiana, Guiana Francesa, Brasil (MA, PE, BA, MT, GO, MG, ES*, RJ, SP, SC e RS), Equador, Bolívia, Paraguai, Argentina e Uruguai. * Nova ocorrência.

Floração e frutificação: janeiro, fevereiro, março, abril, maio, junho, novembro e dezembro.

Habitat: alagados, brejos herbáceos, brejos nas margens de estradas e lagoas e canais.

Material examinado: BRASIL: RIO DE JANEIRO: Quissamã, 22 S 06', 41 W 28', Lado direito da ponte do Imbiú, a 13 km da Prefeitura e a $8 \mathrm{~km}$ do trevo sentido praia de João Francisco, 11XI-2002, A. Gil et al. 45 (R); Idem, ibidem, 11-XI-2002, A. Gil et al. 46 (R); Idem, ibidem, 11-XI-2002, A. Gil et al. 47 (R); Idem, a 27 km da Prefeitura sentido Parque Nacional da Restinga de Jurubatiba, Machado, entorno do Parque, 12-XI-2002, A. Gil et al. 48 (R); Idem, Parque Nacional da Restinga de Jurubatiba, Lagoa Paulista, 13-XI-2002, A. Gil et al. 55 (R); Arraial do Cabo, 22 S 57', 42 W 01', Praia do Pontal, II/III-1951, L. E. M. Filho 1136 (R); Idem, ibidem, 7-V-1953, Segadas-Vianna et al. Restinga I-41 (R); Rio de Janeiro, 22 S 54', 43 W 12', Recreio dos Bandeirantes, Pedra de Itaúna, 16-I-1965, N. Santos 5364 (R); Idem, ibidem, próximo a Pedra de Itaúna, 26-VI-1972, A. L. Peixoto 65 (R); Idem, ibidem, 28-VI-1972, R. Fucks s/n (R-138960); Idem, ibidem, Restinga de Itapeba, Estrada Rio-Santos, 17-I-1967, Segadas-Vianna 4481b (R); Idem, ibidem, Restinga de Itapeba, Estrada Rio-Santos, 17-V-1967, Segadas-Vianna 4481 (R); Idem, ibidem, Restinga de Itapeba, via 11 entre Br-6 e Lagoa de Jacarepaguá, 21-IV-1968, Segadas-Vianna 4581 (R); Angra dos Reis, 23 S 00', 44 W 19', XI-1950, Segadas-Vianna 3061 (R); Idem, próximo ao Rio Bracuhy, na Orla do Manguezal, 17-IX-1980, D. Araújo 4001 \& N. C. Maciel (GUA). 
Material adicional examinado: BRASIL: ESPÍRITO SANTO: Domingos Martins, 20 S 21', 40 W 39', Pedra Azul, Fazenda do Estado (Pousada do Vale da Pedra Azul), 31-XII-2002, C. P. Bove et al. 1090 (R).

Comentários: Eleocharis sellowiana mostrou-se bastante semelhante, em herbário, a E. flavescens, sendo separada, principalmente, pela cor das espigas, superfície e cor dos aquênios e forma da estilopódio (vide comentários em E. flavescens - loc. cit.). Mostra-se, ainda, semelhante a E. filiculmis com a qual compartilha o hábito, a cor e a forma das espigas e da qual se distingue pela forma e textura da bainha (vide comentários E. filiculmis - loc. cit.).

Eleocharis sellowiana apresenta dimensões menores e coloração alaranjada do colmo à medida que a disponibilidade de água diminui. Os espécimes com 8 cerdas têm a oitava cerda vestigial ou bem menor do que as demais.

Gil \& Bove (2004) afirmam que E. sellowiana, por encontrar-se bastante escassa nos ecossistemas aquáticos temporários da planície costeira do estado do Rio de Janeiro, não seria uma espécie infestante, contrapondo-se às afirmações de Lorenzi (2000). O presente trabalho, entretanto, está de acordo com Lorenzi (2000), já que esta espécie mostrou-se bastante difundida e muitas vezes dominante nos ambientes aquáticos permanentes do Estado.

\section{Eleocharis squamigera Svenson, Rhodora 36: 389. 1934. (Figuras 55-57)}

Ervas eretas, cespitosas, estoloníferas. Colmos 5,5-21 cm x 0,2$0,3 \mathrm{~mm}$ na base, quadrangulares, espessamento abaixo da espiga, capilares, estriados longitudinalmente, sulcados, verdes. Bainhas membranáceas, pardo-esverdeadas metade superior, e castanho-avermelhadas a purpúreas na metade inferior, às vezes toda pardo-esverdeadas, com um grupo de máculas castanho-avermelhadas no ápice em

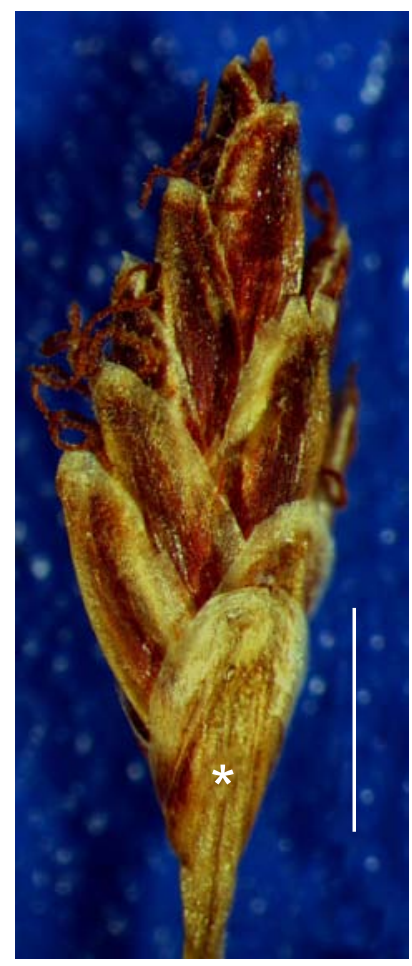

Figura 55. Eleocharis squamigera Svenson (Markgraf 10150). Espiga (*gluma inferior) (barra $=1 \mathrm{~mm})$.

Figure 55. Eleocharis squamigera Svenson (Markgraf 10150). Spike (*lower glume) $($ scale bar $=1 \mathrm{~mm})$ forma triangular, 1,5-2,5 cm de comprimento, sem apêndice hialino no ápice; ápice oblíquo, acuminado, íntegro. Espigas paucifloras a multifloras, proliferação ausente, ovóides a elipsóides, 3-5 x 0,8-1,2 $\mathrm{mm}$, subagudas, castanho-avermelhadas com manchas pardo-esverdeadas. Glumas espiraladas a subdísticas, carenadas, membranáceas, caducas, região da carena verde a parda, lados castanho-avermelhados, oval-lanceoladas a ovaladas, ápice obtuso, margens largas hialinas, íntegras, nervura longitudinal central proeminente, 1,5-2 x 0,6-1 mm. Uma gluma inferior englobando toda a base da espiga, articulada com o colmo, estéril, caduca, região da carena verde a parda, lados castanho-avermelhados, 1-1,5 mm de comprimento e 0,2-0,3 mm de diâmetro, margens hialinas e escariosas, ápice ob-

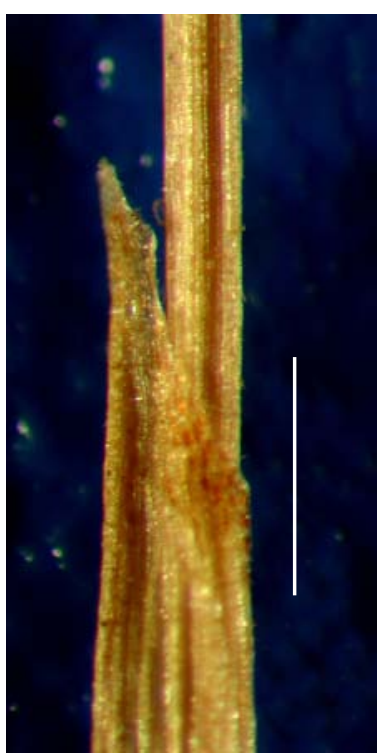

Figura 56. Eleocharis squamigera Svenson (Markgraf 10150). Ápice da bainha (barra $=0,5 \mathrm{~mm}$ ).

Figure 56. Eleocharis squamigera Svenson (Markgraf 10150). Sheath apex (scale bar $=0.5 \mathrm{~mm}$ ).

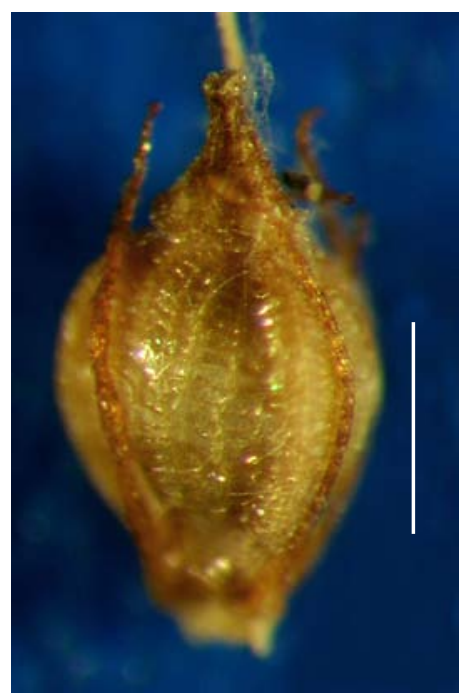

Figura 57. Eleocharis squamigera Svenson (Markgraf 10150). Aquênio (barra $=0,5 \mathrm{~mm}$ ).

Figure 57. Eleocharis squamigera Svenson (Markgraf 10150). Achene (scale bar $=0.5 \mathrm{~mm}$ ). 
tuso. Cerdas perigoniais 6, castanhas, 0,7-1,2 mm de comprimento. Estames 3, filetes amarelados, anteras apiculadas, amarelas. Estigma 3-fido. Aquênios pardos, obovóides, 0,6-0,8 x 0,6-0,7 mm, trígonos, superfície com fileiras longitudinais de células retangulares dispostas horizontalmente, 3-costados, costas formadas de células retangulares, brevemente estipitados, por vezes estípite ausente, ápice com um colo; estilopódio, com ápice castanho e base da cor do aquênio, piramidal, cerca de 0,4-0,5 mm de comprimento.

Nome vulgar: junco.

Distribuição geográfica: AMÉRICA: Venezuela e Brasil (RJ*, SP, PR, SC e RS). * Nova ocorrência.

Floração: setembro, outubro e novembro.

Frutificação: outubro e novembro.

Habitat: barrancos úmidos junto a musgos.

Material examinado: BRASIL: RIO DE JANEIRO: Nova Friburgo, 22 S 16', 42 W 31', estrada da cascata do Pinel, 6-IX-1986, J. C. Siqueira 2120 (FCAB); Teresópolis, 22 S 24', 42 W 57', Serra dos Órgãos, Campo das Antas, X-1952, Markgraf 10150 (RB); Itatiaia, 22 S 29', 44 W 33', 28-VII-1934, Pildes \& Brade 30 (RB).

Comentários: Eleocharis squamigera apresentou-se, no estado do Rio de Janeiro, endêmica nas regiões com grandes altitudes. Apresenta como característica marcante máculas castanho-avermelhadas na base do ápice da bainha, formando um desenho obtriangular. Por vezes, a gluma inferior de $E$. squamigera dá a impressão de que não é única, porém está inserida sozinha na posição mais inferior da espiga, ou seja, todas as outras encontram-se acima desta. Esta espécie mostrou-se semelhante, em herbário, a E. minarum, da qual se distingue pelas diferenças de seus aquênios, bainhas e colmos.

19. Eleocharis subarticulata (Nees) Boeck, Linnaea 36:

455. 1870. (Figuras 58-60)

Chaetocyperus subarticulatus Nees, Fl. Bras. 2: 96.1842.

Ervas eretas, cespitosas, estoloníferas. Colmos 3,5-58 cm x 0,5$1,5 \mathrm{~mm}$ na base, cilíndricos, irregularmente septados, não nodulosos, septos transversais pouco evidentes, estriados longitudinalmente, sulcados ou não, verdes. Bainhas subcoriáceas a membranáceas no ápice, castanhas a purpúreas na base, pardas a esverdeadas acima, 1-4 cm de comprimento, com inconspícuo apêndice hialino no ápice; ápice oblíquo a truncado, acuminado a brevemente mucronado, íntegro. Espigas multifloras, proliferação ausente, oval-lanceoladas a elipsóides, 3,5-13 x 1-2,5 mm, agudas, por vezes subagudas, castanho-escuras. Glumas espiraladas, carenadas, membranáceas, caducas, verdes na região da carena, lados castanhos a purpúreos, às vezes, apenas máculas castanhas a purpúreas beirando internamente a margem hialina em quase toda sua extensão, ovaladas a ovallanceoladas, ápice subagudo, margem hialinas, escariosas, apenas nervura longitudinal central proeminente, $2-3 \times 0,8-1 \mathrm{~mm}$. Duas glumas inferiores, a mais externa englobando toda a base da espiga, contínua com o colmo, com carena bastante larga e verde, lados hialinos ou com máculas castanhas beirando internamente as margens, com 1-1,5 de comprimento e 0,8-1 mm de diâmetro; a mais interna oposta à externa, articulada com o colmo, verdes na região da carena, lados castanhos a purpúreos, às vezes, apenas máculas castanhas a purpúreas beirando internamente a margem hialina, com 2-2,5 x 1-1,2 mm, estéreis, persistentes, margem hialina e íntegra, ápice obtuso. Cerdas perigoniais 6 , alvas a castanhas, 1,5-2 $\mathrm{mm}$ de comprimento. Estames 3, filetes hialinos, anteras brevemente apiculadas, amarelas. Estigma 3-fido. Aquênios oliváceos brilhantes, obovóides, 1-1,4 x 0,6-0,8 mm, trígonos, superfície reticulada, 3-costados, estípite ausente, colo e espessamento ausentes; estilopódio contínuo com o aquênio, esverdeado a castanho, piramidal alongado, 0,5-0,7 mm de comprimento.
Nome vulgar: junco.

Distribuição geográfica: AMÉRICA: Brasil (MG, RJ, SP, PR, SC e RS).

Floração e frutificação: janeiro, fevereiro e dezembro.

Habitat: lagoas, pântanos e solos úmidos.

Material examinado: BRASIL: RIO DE JANEIRO: Itatiaia, 22 S 29', 44 W 33', Serra do Itatiaia, 8-I-1896, E. Ule 660 (R); Idem,

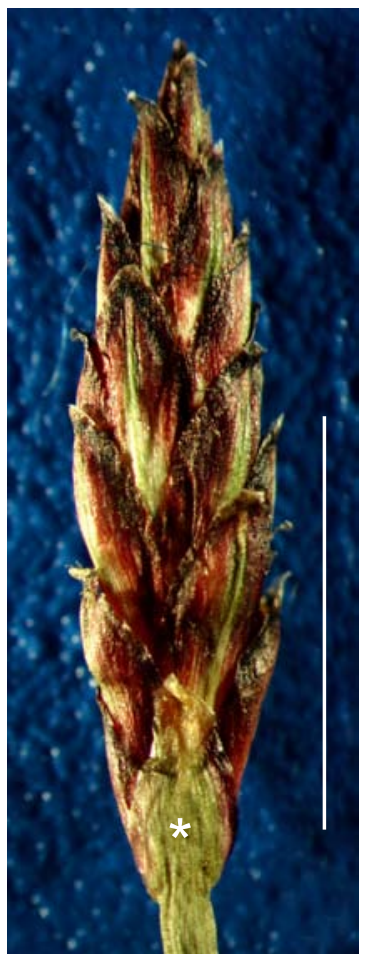

Figura 58. Eleocharis subarticulata (Nees) Boeck. (R. Moura s/nº, R-202181). Espiga (*gluma inferior externa) (barra $=5 \mathrm{~mm}$ ).

Figure 58. Eleocharis subarticulata (Nees) Boeck. (R. Moura s/nº, R-202181). Spike (*external lower glume) (scale bar $=5 \mathrm{~mm})$.



Figura 59. Eleocharis subarticulata (Nees) Boeck. (R. Moura s/nº, R-202181). Ápice da bainha (barra $=1 \mathrm{~mm})$.

Figure 59. Eleocharis subarticulata (Nees) Boeck. (R. Moura s/nº, R-202181). Sheath apex (scale bar $=1 \mathrm{~mm})$. 


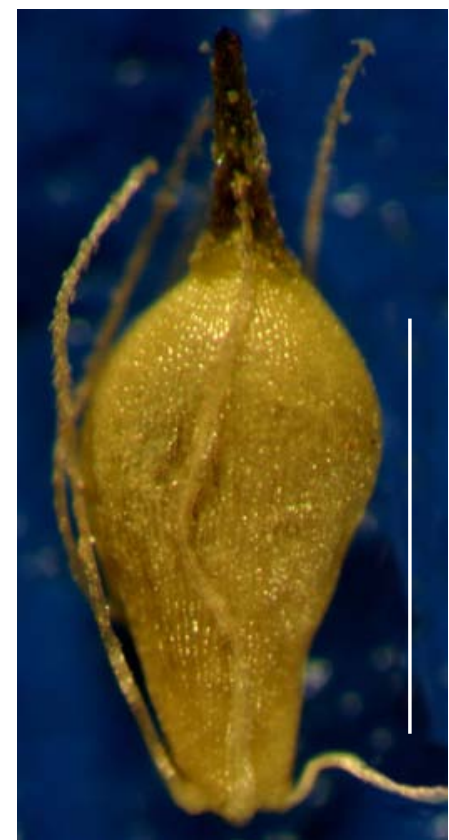

Figura 60. Eleocharis subarticulata (Nees) Boeck. (R. Moura s/nº, R-202181) Aquênio (barra $=1 \mathrm{~mm}$ ).

Figure 60. Eleocharis subarticulata (Nees) Boeck. (R. Moura s/nº, R-202181). Achene (scale bar $=1 \mathrm{~mm}$ ).

I-1952, B. Lutz s/n (R-200989); Idem, estrada para o planalto, perto do abrigo Rebouças, 13-I-1961, H. F. Martins 232 (GUA); Idem, XII2000, R. Moura s/n (R-202181); Resende, 22 S 28', 44 W 26', Serra do Itatiaia, Base das Agulhas Negras, 28-II-1953, Segadas-Vianna et al. Serra I-54 (R); Idem, ibidem, Base das Agulhas Negras, 28-II1953, Segadas-Vianna et al. Serra I-55 (R); Idem, ibidem, 28-II-1953, Segadas-Vianna et al. Serra I-58 (R).

Comentários: No estado do Rio de Janeiro, Eleocharis subarticulata é endêmica da serra do Itatiaia. Esta espécie pode ser confundida com E. elongata, distinguindo-se, principalmente, pela textura das glumas, tamanho e fertilidade da gluma inferior, superfície e ornamentação dos aquênios (vide comentários E. elongata - loc. cit.).

\section{Considerações finais}

O gênero Eleocharis está representado no Estado do Rio de Janeiro por 19 espécies: Eleocharis acutangula (Roxb.) Schult., E. debilis Kunth, E. elongata Chapm., E. equisetoides (Elliott) Torr., E. filiculmis Kunth, E. flavescens (Poir.) Urb., E. geniculata (L.) Roem. \& Schult., E. interstincta (Vahl) Roem. \& Schult., E. maculosa (Vahl) Roem. \& Schult., E. minarum Boeck., E. minima Kunth, E. montana (Kunth) Roem. \& Schult., E. mutata (L.) Roem. \& Schult., E. nana Kunth, E. pachystyla (C. Wright) C. B. Clarke, E. radicans (Poir.) Kunth, E. sellowiana Kunth, E. squamigera Svenson e E. subarticulata (Nees) Boeck. É clara a necessidade de intensificação das coletas na área de estudo, já que para o estado de São Paulo foram encontradas 36 espécies (Faria 1998), para o estado de Santa Catarina 25 espécies (Barros 1960) e para o estado do Rio Grande do Sul 27 espécies (Trevisan 2005).

Constatou-se novas ocorrências para o Estado do Rio de Janeiro: Eleocharis equisetoides, E. minarum, E. pachystyla, E. radicans e E. squamigera, a primeira ainda para os Estados da Paraíba e Bahia. Constatou-se, também, novas ocorrências de Eleocharis acutangula, E. filiculmis e E. interstincta para o Estado de Goiás e de Eleocharis sellowiana para o Estado do Espírito Santo. Este significativo número de novos registros ratifica a carência de trabalhos envolvendo as Ciperáceas, principalmente Eleocharis.

Algumas das espécies encontradas no estado do Rio de Janeiro mostraram-se raras, entre elas, Eleocharis minarum, E. pachystyla e E. radicans. Em contrapartida Eleocharis geniculata mostrou-se a mais abundante dentre as espécies encontradas (57 espécimes), a Praia do Pontal no município de Arraial do Cabo foi a localidade que mais contribuiu para este elevado número de espécimes examinados, pois foram realizadas coletas sistemáticas nesta localidade em meados do século passado. No decorrer deste trabalho foram realizadas algumas excursões à Praia do Pontal e, surpreendentemente, nenhum exemplar de E. geniculata foi encontrado. Especula-se que este fato possa ser justificado pela forte atividade antrópica local, ou ainda, adicionalmente, pelo forte dinamismo desta praia.

O presente estudo deixa clara a necessidade de estudos florísticos para estas espécies e seu respectivo estudo taxonômico, para a implementação de pesquisas mais elaboradas nestas áreas, na tentativa de sua preservação e manejo. A cada ano, intensifica-se a especulação imobiliária e turística, aumentando o descaso à vegetação nativa e, conseqüentemente, aumentando risco de extinção da flora e fauna.

\section{Agradecimentos}

Aos Drs. Ana Claudia Araújo (UNIVALE), Elsie Franklin Guimarães (IPJBRJ), Jorge Fontella Pereira (MN/UFRJ), Ruy Valka (MN/ UFRJ) e dois revisores anônimos, pelas sugestões que contribuíram significativamente pela melhoria da qualidade do trabalho; ao Dr. Clovis Barreira e Castro e Dra. Débora de Oliveira Pires (Setor de Celenterologia - MN/UFRJ), por cederem o equipamento em que foram tiradas as fotografias; aos Msc. Pedro Costa, Marcelo Medeiros e José Eduardo Meireles, pelo auxílio para aquisição das fotografias em estereomicroscópio; a CAPES, pela bolsa concedida a realização do mestrado do primeiro autor; aos funcionários dos herbários FCAB, GUA, HB,R, RBE, RFA, RB e USU pela colaboração nas consultas aos seus respectivos herbários.

\section{Referências Bibliográficas}

ADAMS, C. D. 1994. Cyperaceae. In Flora mesoamericana 6 (G. Davidse, M. Sousa \& A.O. Chater, eds.). Universidad Nacional Autónoma de México, Cidade do México, p.402-485.

ARAÚJO, D.S.D., SCARANO, F., SÁ, C.F.C., KURTZ, B., ZALUAR, H.L.T., MONTEZUMA, R.C.M. \& OLIVEIRA, R.C. 1998. Comunidades vegetais do Parque Nacional da Restinga de Jurubatiba. In Ecologia das lagoas costeiras do Parque Nacional da Restinga de Jurubatiba e do município de Macaé (RJ) (F. A. Esteves, ed.). NUPEM/UFRJ, Rio de Janeiro, p.39-62.

BARROS, M. 1960. Las Ciperaceas del Estado de Santa Catalina. Sellowia 12:181-450.

BLAKE, S.T. 1938. A monograph of the Genus Eleocharis in Australia and New Zealand. Proc. Roy. Soc. Queensland, 50(12):88-132.

BOVE, C.P., GIL, A.S.B., MOREIRA, C.B. \& ANJOS, R.F.B. 2003. Hidrófitas fanerogâmicas de ecossistemas aquáticos temporários da planície costeira do Estado do Rio de Janeiro, Brasil. Acta Bot. Bras. 17(1):119-135.

BRUHL, J.J. 1994. Amphicarpy in the Cyperaceae, with novel variation in the wetland sedge Eleocharis caespitosissima Backer. Aust. J. Bot. 42:441-448.

BRUHL, J.J. 1995. Sedge genera of the world: relationships and a new classification of the Cyperaceae. Austral. Syst. Bot. 8(2):125-305.

CHAPMAN, A.W. 1860. Flora of the southern United States. Ivison, Phinney and Co., New York.

DIEGO-PÉREZ, N. 1997. Cyperaceae. In Flora de Gerrero 5 (N. Diego-Pérez \& R. Maria Fonseca, eds.). Universidad Nacional Autónoma de México, Cidade do México, p.1-169. 
DUBS, B. 1998. Prodromus Florae Matogrossensis. The Botany of Mato Grosso. Betrona-Verlag, Switzerland.

FARIA, A.D. 1998. O gênero Eleocharis R. Br. (Cyperaceae) no Estado de São Paulo. Dissertação de Mestrado, Universidade Estadual de Campinas, Campinas.

GIL, A.S.B. 2004. Eleocharis R. Br. (Cyperaceae) no Estado do Rio de Janeiro. Dissertação de Mestrado, Universidade Federal do Rio de Janeiro, Rio de Janeiro.

GIL, A.S.B. \& BOVE, C.P. 2004. O gênero Eleocharis R. Br. (Cyperaceae) nos ecossistemas aquáticos temporários da planície costeira do Estado do Rio de Janeiro. Arq. Mus. Nac., Rio de Janeiro, 62(2):131-150.

GOETGHEBEUR, P. 1998. Cyperaceae. In The Families and Genera of Vascular Plant IV. Flowering Plants-Monocotyledons. (K. Kubitzki, ed.). Springer-Verlag, Berlin, p.141-190.

GONZÁLEZ-ELIZONDO, M.S. 1994. Eleocharis. In Flora mesoamericana 6 (G. Davidse, M. Sousa \& A.O. Chater, eds.). Universidad Nacional Autónoma de México, Cidade do México, p.458-464.

GONZÁLEZ-ELIZONDO, M.S. \& REZNICEK, A.A. 1996. New Eleocharis (Cyperaceae) from Venezuela. Novon 6:356-365.

GONZÁLEZ-ELIZONDO, M.S. \& REZNICEK, A.A., 1998. Eleocharis. In Flora of the Venezuelan Guayana. Caesalpinaceae-Ericaceae (J. A. Steyermark, P. E. Berry \& B. K. Holst, eds.). Missouri Botanical Garden Press., Saint Louis, v.4, p.548-561.

GONZÁLEZ-ELIZONDO, M.S. \& PETERSON, M.P. 1997. A classification of and key to the supraspecific taxa in Eleocharis (Cyperaceae). Taxon 46:433-445.

GONZÁLEZ-ELIZONDO, M.S., GONZÁLEZ-ELIZONDO, M. \& SMITH, S.G. 2002. Eleocharis Obtusetrigona (Cyperaceae) new to North and Central America. Acta Bot. Mex 60:7-11.

GREUTER, W., MCNEILL, J., BARRIE, F.R., BURDET, H.M., DEMOULIN, V., FILGUEIRAS, T.S., NICOLSON, D.H., SILVA, P.C., SKOG, J.E., TREHANE, P., TURLAND, N.J. \& HAWKSWORTH, D. L. 2000. International code of botanical nomenclature. Koeltz Scientific Books, Königstein.

GUAGLIANONE, E. R. 2001. Contribution to the study of the genus Rhynchospora (Cyperaceae) V. Section Longirostres in Austral America. Darwiniana 39(3-4):287-342.

HITCHCOCK, C.L., CRONQUIST, A., OWNBEY, M. \& THOMPSON, J.W. 1969. Vascular Plants of the Pacific Northwest 1. Vascular Cryptogams, Gymnosperms, and Monocotyledons. University of Washinton Press, Seattle and London.

HOLMGREN, P.K., HOLMGREN, N.H. \& BARNETT, L.C. 1990. The Herbaria of the World. New York Botanical Garden, New York.

IRGANG, B.E. \& GASTAL Jr., C.V.S. 1996. Macrófitas Aquáticas da Planície Costeira do RS. Editora Porto Alegre, Porto Alegre.

JANCHEN, E. 1950. Proposal 22. In Synopsis of proposals concerning the international rules of botanical nomenclature submitted to the seventh International Botanical Congress (J. Lanjouv, ed.). Stockolm. p. 255.

JORGENSEN, P.M. \& ULLOA, C. 1994. Seed plants of the High Andes of Ecuador - a checklist. AAU Reports 34:182-188.

JUDD, W.S., CAMPBELL, C.S., KELLOGG, E.A. \& STEVENS, P.F. 2002. Plant Systematics, a Phylogenetic Approach. 2 ed. Sinaver Associates, Inc., Sunderland.

KOYAMA, T. 1961. Classification of the family Cyperaceae. J. Fac. Sci. Univ. Tokyo, Sect. 3, Bot. 8(3):84-99.

KUNTH, C.S. 1837. Enumeratio plantarum amnium hucusque cognitarum. 2. Cyperographia. Tubingen, Stuttgart.

KUKKONEN, I. 1990. On the genus Eleocharis (Cyperaceae) in the Flora Iranica area, with revised infrageneric classification and nomeclature. Ann. Bot. Fennici 27:109-117.

KUHLMANN, M. \& KÜHN, E. 1947. A Flora do Distrito de Ibiti (ex - Monte Alegre), Município de Amparo. Instituto de Botânica, São Paulo.

LAWESSON, J.E., ADSERSEN, H. \& BENTLEY, P. 1987. An updated and annotated checklist of the vascular plants of the Galapagos Islands. Report. Bot. Inst. Univ. AARHUS 16:67-69.
LORENZI, H. 2000. Plantas Daninhas do Brasil: Terrestres, Aquáticas, Parasitas e Tóxicas. Editora Platarum, Nova Odessa.

LUCEÑO, M., ALVES, M.V. \& MENDES, A.P. 1997. Catálogo florístico y claves de identificación de las Ciperáceas de los Estados de Paraíba y Pernambuco (Nordeste do Brasil). Anales Jard. Bot. Madrid 55 (1): $67-100$.

MARTICORENA, C. \& QUEZADA, M. 1985. Flora vascular de Chile. Gayana, Bot. 42(1-2):81-83.

MARTINS, M.L.L., CARVALHO-OKANO, R.M. \& LUCEÑO, M. 1999. Cyperaceae do Parque Estadual Paulo César Vinha, Guarapari, Espírito Santo, Brasil. Acta Bot. Bras. 13(2):187-222.

MENAPACE, F.J. 1991. A preliminary micromorphological analysis of Eleocharis (Cyperaceae) achenes for systematic potential. Canad. J. Bot. 69:1533-1541.

MENAPACE, F.J. 1993. Achene micro-morphology as a systematic aid to the series placement of Svenson's undesignated Eleocharis (Cyperaceae) species. Rhodora 95(883/884):214-224.

MENDOZA, R.E. \& GONZALEZ, J.E. 1991. Plantas Acuáticas de Panamá. Editorial Universitária, Panamá.

MISSOURI BOTANICAL GARDEN. 2006. W³ tropics database. Disponível em: <http:// mobot.mobot.org/W3T/Search/vast.html>. Acesso em 10 jan. 2006.

MOLFINO, J.F. 1925. Monocotiledóneas nuevas para la Argentina. Physis 8:108-110.

MORI, S.A., SILVA, L.A.M., LISBOA, G. \& CORADIN, L. 1989. Manual de Manejo de Herbário Fanerogâmico. Centro de Pesquisas do Cacau, Ilhéus.

MUENSCHER, W.C. 1944. Aquatic Plants of the United States. Cornell University Press, New York.

MUNIZ, C.F.S. 2001. Cyperaceae. In Flora do Parque Nacional da Restinga de Jurubatiba e arredores, Rio de Janeiro, Brasil: listagem florística e fitogeografia: Angiospermas, Pteridófitas, Algas continentais (A. F. Costa \& I. C. A. Dias, orgs.). Série Livros Museu Nacional 8, Rio de Janeiro, p.60-63.

MUNIZ, C.F.S. \& SHEPHERD, G. 1987. O Gênero Scleria Berg. (Cyperaceae) no estado de São Paulo. Rev. Bras. Bot. 10:63-94.

NEES, C.G. 1842. Cyperaceae. In Flora Brasiliensis (C.F.P. Martius, ed.). F. Fleischer, Lipsiae, v. 2, pars 1, p.1-226.

NELSON, C. 1978. Contribuciones a la flora de la Mosquitia, Honduras. Ceiba 22(1):41-64.

OLIVEIRA, E.C. 1980. Cyperaceae Juss. morfologia dos aquênios de gêneros ocorrentes no Brasil. Rodriguésia 32(55):327-405.

OSTEN, C. 1931. Las Ciperáceas del Uruguay. Anales Mus. Nac. Montevideo 3(2):108-256.

PARODI, L.R. 1943. La vegetación del Departamento de San Martín en Corrientes (Argentina). Darwiniana 6(2):127-178.

PEDRALLI, G. \& GONÇALVES, A.P.S. 1997. Levantamento florístico e aspectos da sucessão em duas lagoas na região cárstica de Minas Gerais, Brasil. Daphne 7(3):17-25.

PEDRALLI, G., STEHMANN, J.R., TEIXEIRA, M.C.B., OLIVEIRA, V.L. \& MEYER, S.T. 1993. Levantamento da vegetação aquática (macrófitas) na área da EPDA-Peti, Santa Bárbara, MG. Iheringia, sér. bot. 43:15-28.

POTT, V.J. \& POTT, A. 1997. Checklist das macrófitas aquáticas do Pantanal, Brasil. Mato Grosso do Sul. Acta Bot. Bras. 11(2):215-227.

POTT, V.J., REGO, S.C.A. \& POTT, A. 1986. Plantas uliginosas e aquáticas do pantanal arenoso. Embrapa-CPAP, Pesquisa em andamento 6:1-13.

PRATA, A.P. 2002. Listagem florística das Cyperaceae do Estado de Roraima, Brasil. Hoehnea 29(2):93-107.

RENNER, S.S., BALSLEV, H. \& HOLM-NIELSEN, L.B. 1990. Flowering plants of Amazonian Ecuador - a checklist. AAU Reports 24:88-90.

ROALSON, E.H. \& FRIAR, E.A. 2000. Infrageneric classification of Eleocharis (Cyperaceae) revisited: evidence from the Internal Transcribed Spacer (ITS) region of nuclear ribosomal DNA. Syst. Bot. 25(2):323-336. 
ROEMER, J.J. \& SCHULTES, J.A. 1817. Eleocharis. In Systema Vegetabilium, 15 ed. (C. Linnaeus, ed.). Stuttgard, v.1, pars 1. p.149-159.

ROSA, F.F. \& IRGANG, B.E. 1998. Comunidades vegetais de um segmento da planície de inundação do Rio dos Sinos, Rio Grande do Sul, Brasil. Iheringia, Sér. Bot. 50:75-87.

SAMPAIO, A.J. 1916. A flora do Mato Grosso. Arq. Mus Nac. Rio de Janeiro, 19:1-125.

SCHESSL, M. 1999. Floristic composition and structure of floodplain vegetation in the Northern pantanal of Mato Grosso. Brazil. Phyton 39(2):303-336.

SIMPSON, D.A. 1995. Cyperaceae. In Flora of the Pico das Almas (B. Stannard, ed.). Royal Botanic Gardens, Kew, London, p. 661-683.

SOLTIS, D.E., SOLTIS, P.S., ENDRESS, P.K. \& CHASE, M.W. 2005. Phylogeny and evolution of Angiosperms. Sinaver Associates, Inc., Sunderland.

STANDLEY, P.C. 1931. The Cyperaceae of Central America. Field Mus. Nat. Hist., Bot. Ser. 8(4):239-292.

STANDLEY, P.C. \& STEYERMARK, J.A. 1958. Cyperaceae (P.C. Standley \& J. A. Steyermark, eds.). Fieldiana. Bot. 24(1):90-196

SVENSON, H.K. 1929. Monographic studies in the genus Eleocharis. Rhodora 31:121-135, 152-163, 167-191, 199-219, 224-242.

SVENSON, H.K. 1932. Monographic studies in the genus Eleocharis. Rhodora 34:193-203, 215-227.

SVENSON, H.K. 1934. Monographic studies in the genus Eleocharis. Rhodora 36:377- 389.

SVENSON, H.K. 1937. Monographic studies in the genus Eleocharis. Rhodora 39:210-231, 236-273.

SVENSON, H.K. 1939. Monographic studies in the genus Eleocharis. Rhodora 41:1-19, 43-77, 90-110.

SVENSON, H.K. 1943. Cyperaceae. In Flora of Panamá (R.E. Woodson \& R.W. SCHERY, eds.). Ann. Missouri Bot. Gard. 30(3):281-325.

TORREY, J. 1836. Monograph of North American Cyperaceae. Annals of the Lyceum of Natural History of New York. v. 3. New York, New York.
TREVISAN, R. 2005. O gênero Eleocharis R. Br. (Cyperaceae) no Rio Grande do Sul. Dissertação de mestrado, Universidade Federal do Rio Grande do Sul, Porto Alegre.

TREVISAN, R. \& BOLDRINI, I.I. 2005. Eleocharis ochrostachys Steud. (Cyperaceae) nova ocorrência para os Estados do Rio Grande do Sul e de Santa Catarina, Brasil. Acta Bot. Bras. 19(4):695-699.

TREVISAN, R. \& BOLDRINI, I.I. 2006. A new species of Eleocharis R. Brown (Cyperaceae) from Southern Brazil. Novon 16:155-157.

UENO, O., SAMEJIMA, M. \& KOYAMA, T. 1989. Distribution and evolution of C4 syndrome in Eleocharis, a sedge group inhabiting wet and aquatic environments, based on culm anatomy and carbon isotope ratios. Ann. Bot. 64(4):425-438.

UENO, O. \& TAKEDA, T. 1992. Photosynthetic pathways, ecological characteristics, and the geographical distribution of the Cyperaceae in Japan. Oecologia 89:195-203.

VELASQUEZ, J. 1994. Plantas acuáticas vasculares de Venezuela. Universidad Central de Venezuela, Caracas.

Titulo: Eleocharis R.Br. (Cyperaceae) no Estado do Rio de Janeiro, Brasil.

Autores: Gil, ASB e Bove, CP

Biota Neotropica, Vol.7 (número 1): 2007

http://www.biotaneotropica.org.br/v7n1/pt/abstract? taxonomic-review+bn00507012007

Recebido em 26/05/06 - Versão reformulada recebida em 10/11/06 - Publicado em 01/01/07

ISSN 1676-0603 